\title{
25. RADIOLARIA FROM THE EASTERN INDIAN OCEAN, DSDP LEG $22^{1}$
}

David A. Johnson, Woods Hole Oceanographic Institution, Woods Hole, Massachusetts

\section{CONTENTS}

Introduction

Scope of Investigation and Presentation of

Results

Cenozoic Radiolarian Zonation

Radiolarians at Each Site

Time-ranges of Taxa

Evolutionary Lineages

Discussion of Results

Preservation of Radiolarian Assemblages

Reworking

Unconformities

Diagenesis

Comparison with Equatorial Pacific

Assemblages

\section{INTRODUCTION}

All of the Leg 22 drilling sites yielded radiolarians. The localities of these sites are as follows:

\begin{tabular}{|c|c|c|c|c|}
\hline Site & Latitude & Longitude & $\begin{array}{c}\text { Water } \\
\text { Depth (m) }\end{array}$ & General Location \\
\hline 211 & $09^{\circ} 46.53^{\prime} \mathrm{S}$ & $102^{\circ} 41.95^{\prime} \mathrm{E}$ & 5528 & Nicobar Abyssal Fan \\
\hline 212 & $09^{\circ} 11.34^{\prime} \mathrm{S}$ & $99^{\circ} 17.84^{\prime} \mathrm{E}$ & 6240 & Wharton Basin \\
\hline 213 & $10^{\circ} 12.71^{\prime} \mathrm{S}$ & $93^{\circ} 53.77^{\prime} \mathrm{E}$ & 5609 & $\begin{array}{l}\text { East of Ninetyeast } \\
\text { Ridge }\end{array}$ \\
\hline 214 & $11^{\circ} 20.21^{\prime} \mathrm{S}$ & $88^{\circ} 43.08^{\prime} \mathrm{E}$ & 1671 & Ninetyeast Ridge \\
\hline 215 & $08^{\circ} 07.30^{\prime} \mathrm{S}$ & $86^{\circ} 47.50^{\prime} \mathrm{E}$ & 5321 & $\begin{array}{l}\text { West of Ninetyeast } \\
\text { Ridge }\end{array}$ \\
\hline 216 & $01^{\circ} 27.73^{\prime} \mathrm{N}$ & $90^{\circ} 12.48^{\prime} \mathrm{E}$ & 2262 & Ninetyeast Ridge \\
\hline 217 & $08^{\circ} 55.57^{\prime} \mathrm{N}$ & $90^{\circ} 32.33^{\prime} \mathrm{E}$ & 3030 & Ninetyeast Ridge \\
\hline 218 & $08^{\circ} 00.42^{\prime} \mathrm{N}$ & $86^{\circ} 16.97^{\prime} \mathrm{E}$ & 3737 & Bengal Fan \\
\hline
\end{tabular}

Radiolarians occur only sparsely at Sites 211,212 , and 218. At Sites 213 through 217, radiolarians are common and well preserved through significant lengths of the cored material. The lithologies and stratigraphic ranges of the radiolarian-bearing sediments cored on Leg 22 are shown in Figure 1.

\section{SCOPE OF INVESTIGATION AND PRESENTATION OF RESULTS}

Samples for radiolarian investigation were taken at intervals of approximately one sample per section (1 section $\cong 150 \mathrm{~cm}$ ) from those cores in which the material contains siliceous microfossils. Certain cored intervals

\footnotetext{
${ }^{1}$ Contribution No. 3102 of the Woods Hole Oceanographic Institution.
}

$\begin{array}{ll}\text { Systematic Section (Cenozoic Forms) } & 544 \\ \text { Collosphaeridae } & 544 \\ \text { Actinommidae } & 544 \\ \text { Coccodiscidae } & 545 \\ \text { Spongodiscidae } & 545 \\ \text { Acanthodesmiidae } & 546 \\ \text { Theoperidae } & 547 \\ \text { Carpocaniidae } & 550 \\ \text { Pterocorythidae } & 550 \\ \text { Artostrobiidae } & 552 \\ \text { Cannobotryidae } & 552 \\ \text { Acknowledgments } & 553 \\ \text { References } & 553 \\ \text { Plates } & 555\end{array}$

where lithologic changes were commonplace, such as the cores at Hole $217 \mathrm{~A}$, were sampled at much closer intervals. Slides of coarse fraction preparations ( $>62$ microns) were prepared according to the standard techniques described by Riedel (1957).

All samples were examined and described in a preliminary way for the purposes of this report. Assemblages from several intervals in the Cenozoic appeared to contain forms which are currently undescribed or whose stratigraphic ranges have not been determined. These forms will be treated in a more detailed investigation of the Leg 22 material and other Indian Ocean cores, which will be undertaken following the publication of this report.

The primary purpose of this study was to determine the occurrences at Leg 22 Sites of radiolarian taxa previously known to be stratigraphically useful. These data are discussed and summarized in tabular form in the next section, "Radiolarians at Each Site". Two of the sites, 214 and 216 , together recovered continuously cored radiolarianrich sediment representing the Quaternary through upper Eocene. The drilling depths at these two sites have been used as a scale for tabulating the upper and lower limits of the Cenozoic taxa used in this study (see Figure 2).

Calcareous microfossils cooccur with Radiolaria in most sections in which Radiolaria are present (see Figure 1). As a result, a correlation can be established between the radiolarian ranges and zonations and the standard nannoplankton and foraminiferal zonations, as has been done in previous reports (Bronnimann et al., 1971). These correlations are presented and discussed in the "Biostratigraphic Synthesis" (Chapter 40).

Since much of the eastern Indian Ocean has been presumed to be of pre-Cenozoic age (Smith and Hallam, 1970; Dietz and Holden, 1970; Tarling, 1971; McKenzie and Sclater, 1971), it was anticipated that several of the 


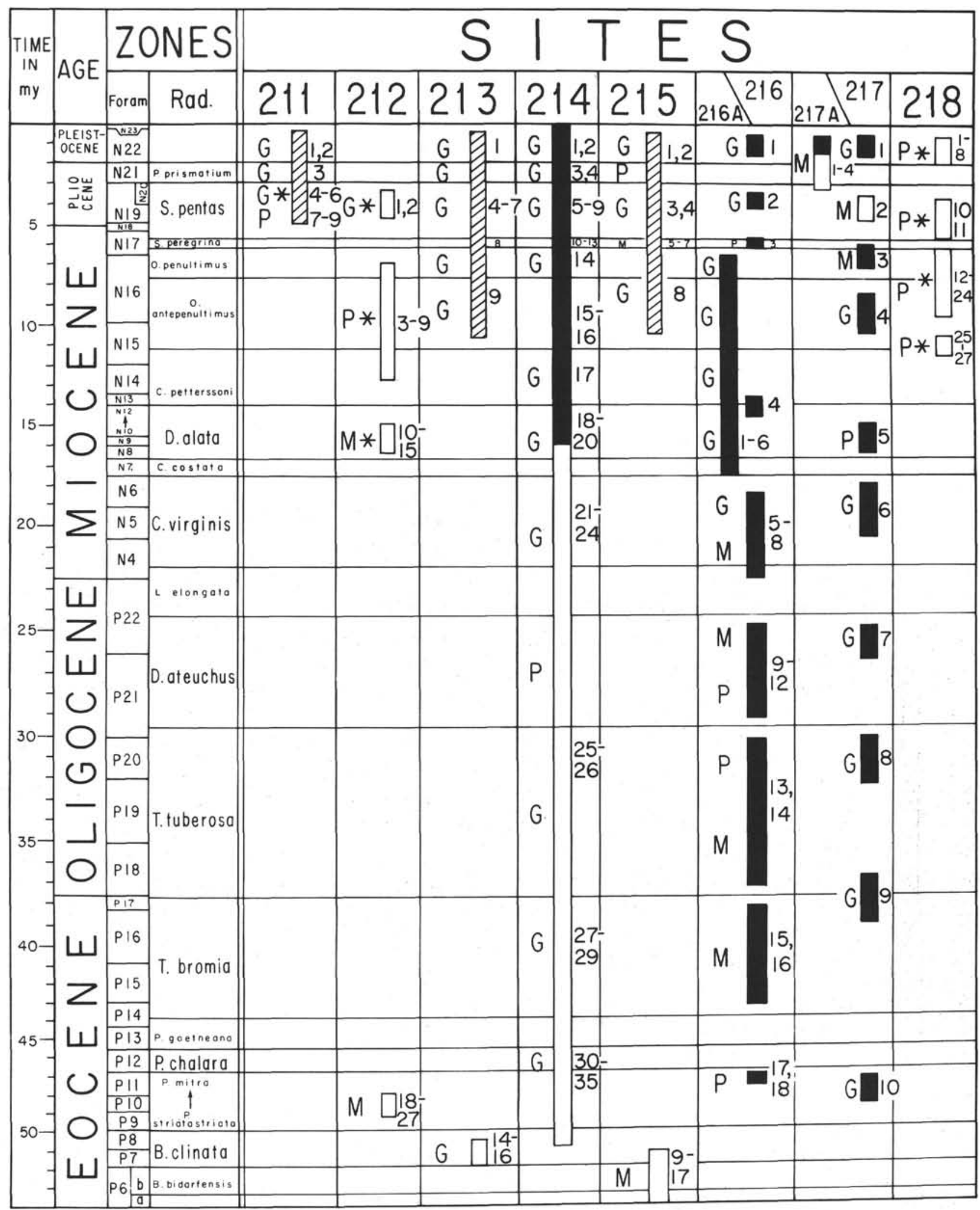

Figure 1. Ages of radiolarian-bearing cores obtained on DSDP Leg 22. Solid pattern indicates sediments containing both calcareous and siliceous microfossils. Diagonal lines indicate sediments with only siliceous microfossils; open pattern indicates where only calcareous microfossils are present. Numbers of cores are shown to the right of the lithologic symbols. Core recovery is indicated by the symbols "G" (good, >75\%), "M" (moderate, 25\% to 75\%), or "P" (poor, $<25 \%$ ). An asterisk indicates those cores in which a substantial proportion of the microfossil assemblage appears to be reworked.

Correlation of foraminiferal zonation with geologic epochs and "absolute" ages is after Berggren (1972). Correlation of Eocene radiolarian zonation with foraminiferal zonation is after Foreman (1973) and Sanfilippo and Riedel (1973). Correlation of post-Eocene radiolarian zonation with foraminiferal zonation is after Berggren (1972). 
Leg 22 sites might yield sequences of Cretaceous radiolarian assemblages. Unfortunately, this was not the case. With one exception (Site 216, Cores 30 and 31), the Cretaceous cores were found to be barren of siliceous microfossils, presumably due to alteration of the siliceous material to chert. Consequently, the rare Cretaceous occurrences will be treated only briefly in this report. The ranges of taxa considered, and the systematics presented, will apply only to Cenozoic forms.

In the discussion which follows and in the tabulations, the names of most radiolarian taxa have been abbreviated. Their full and correct form is given in the Systematics Section.

\section{CENOZOIC RADIOLARIAN ZONATION}

Investigations of sediments cored on earlier legs of the Deep Sea Drilling Project have yielded a radiolarian zonation which covers most of the Cenozoic. This zonation scheme will be followed in this report. The zonal boundaries and ranges of taxa for the Upper Paleocene to Lower Eocene are described by Sanfilippo and Riedel (1973) and Foreman (1973); the zonation for the Middle to Upper Eocene is that of Riedel and Sanfilippo (1970), as modified by Foreman (1973); the zonation used for the Oligocene through Pliocene is that of Riedel and Sanfilippo (1971). No attempt was made to utilize radiolarian zonal boundaries within the Quaternary.

The Cenozoic radiolarian zones used in this study, along with the definitions of the zonal boundaries, are listed below in order from oldest to youngest:

\section{Paleocene}

Bekoma bidarfensis Zone ${ }^{2}$

Base: First evolutionary appearance of Bekoma bidarfensis from Bekoma campechensis.

\section{Eocene}

Buryella clinata Zone ${ }^{2}$

Base: First evolutionary appearance of Buryella clinata from Buryella tetradica.

Phormocyrtis striata striata Zone ${ }^{2}$

Base: First evolutionary appearance of Phormocyrtis striata striata from Phormocyrtis striata exquisita.

Theocotyle cryptocephala cryptocephala Zone ${ }^{2}$

Base: First evolutionary appearance of Theocotyle cryptocephala cryptocephala from Theocotyle cryptocephala nigriniae.

Theocampe mongolfieri Zone

Base: First evolutionary appearance of Theocampe mongolfieri from Theocampe amphora

Thyrsocyrtis triacantha Zone

Base: First evolutionary appearance of Thyrsocyrtis triacantha from Thyrsocyrtis hirsuta tensa.

Podocyrtis ampla Zone

Base: First evolutionary appearance of Podocyrtis ampla from Podocyrtis phyxis.

Podocyrtis mitra Zone

\footnotetext{
${ }^{2}$ Not sampled on Leg 22 .
}

Base: First evolutionary appearance of Podocyrtis mitra from Podocyrtis sinuosa.

Podocyrtis chalara Zone ${ }^{2}$

Base: First evolutionary appearance of Podocyrtis chalara from Podocyrtis mitra.

Podocyrtis goetheana Zone $^{2}$

Base: First evolutionary appearance of Podocyrtis goetheana from Podocyrtis chalara.

Thyrsocyrtis bromia Zone

Base: First evolutionary appearance of Thyrsocyrtis bromia.

\section{Oligocene}

Theocyrtis tuberosa Zone

Base: First evolutionary appearance of Lithocyclia angustum from Lithocyclia aristotelis.

Dorcadospyris ateuchus Zone

Base: First evolutionary appearance of Dorcadospyris ateuchus from Dorcadospyris triceros.

Lychnocanoma elongata Zone (synonymous with Lychnocanium bipes Zone)

Base: First morphotypic appearance of Lychnocanoma elongata.

Miocene

Calocycletta virginis Zone

Base: First evolutionary appearance of Calocycletta virginis from Calocycletta robusta.

Calocycletta costata Zone

Base: First evolutionary appearance of Calocycletta costata from Calocycletta virginis.

Dorcadospyris alata Zone

Base: First evolutionary appearance of Dorcadospyris alata.

Cannartus (?) petterssoni Zone

Base: First morphotypic appearance of Cannartus (?) petterssoni.

Ommatartus antepenultimus Zone

Base: First evolutionary appearance of Ommatartus antepenultimus from Cannartus laticonus.

Ommatartus penultimus Zone

Base: First evolutionary appearance of Ommatartus penultimus from Ommatartus antepenultimus.

Stichocorys peregrina Zone

Base: First evolutionary appearance of Stichocorys peregrina from Stichocorys delmontensis.

\section{Pliocene}

Spongaster pentas Zone

Base: First morphotypic appearance of Pterocanium prismatium

Pterocanium prismatium Zone

Base: Last occurrence of Stichocorys peregrina

\section{Quaternary}

Unzoned

Base: Last occurrence of Pterocanium prismatium

\section{RADIOLARIANS AT EACH SITE}

In this section, the information on occurrences of Cenozoic radiolarians is tabulated in Tables 1 through 5 for 


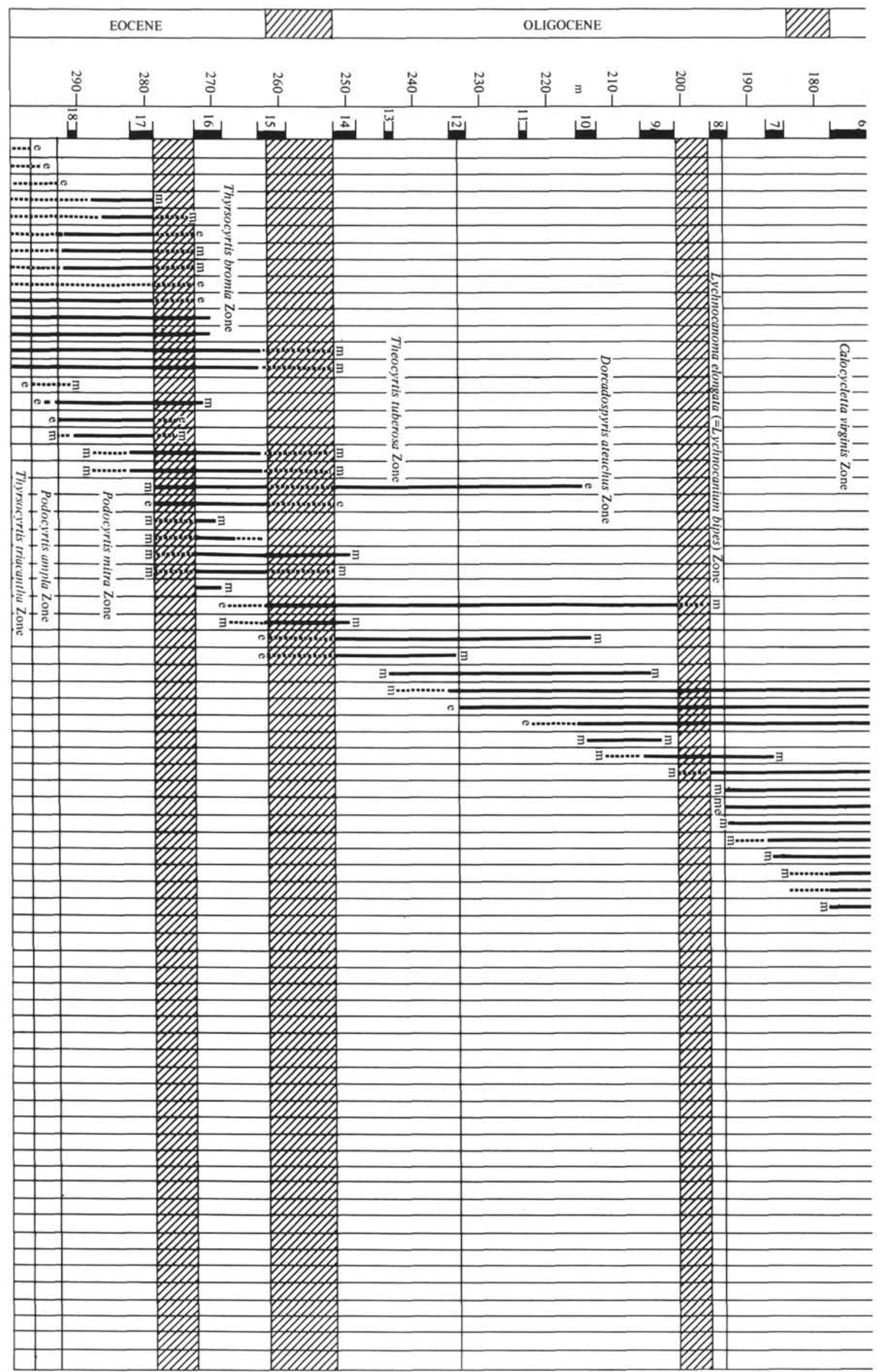

Figure 2. 
RADIOLARIA FROM THE EASTERN INDIAN OCEAN

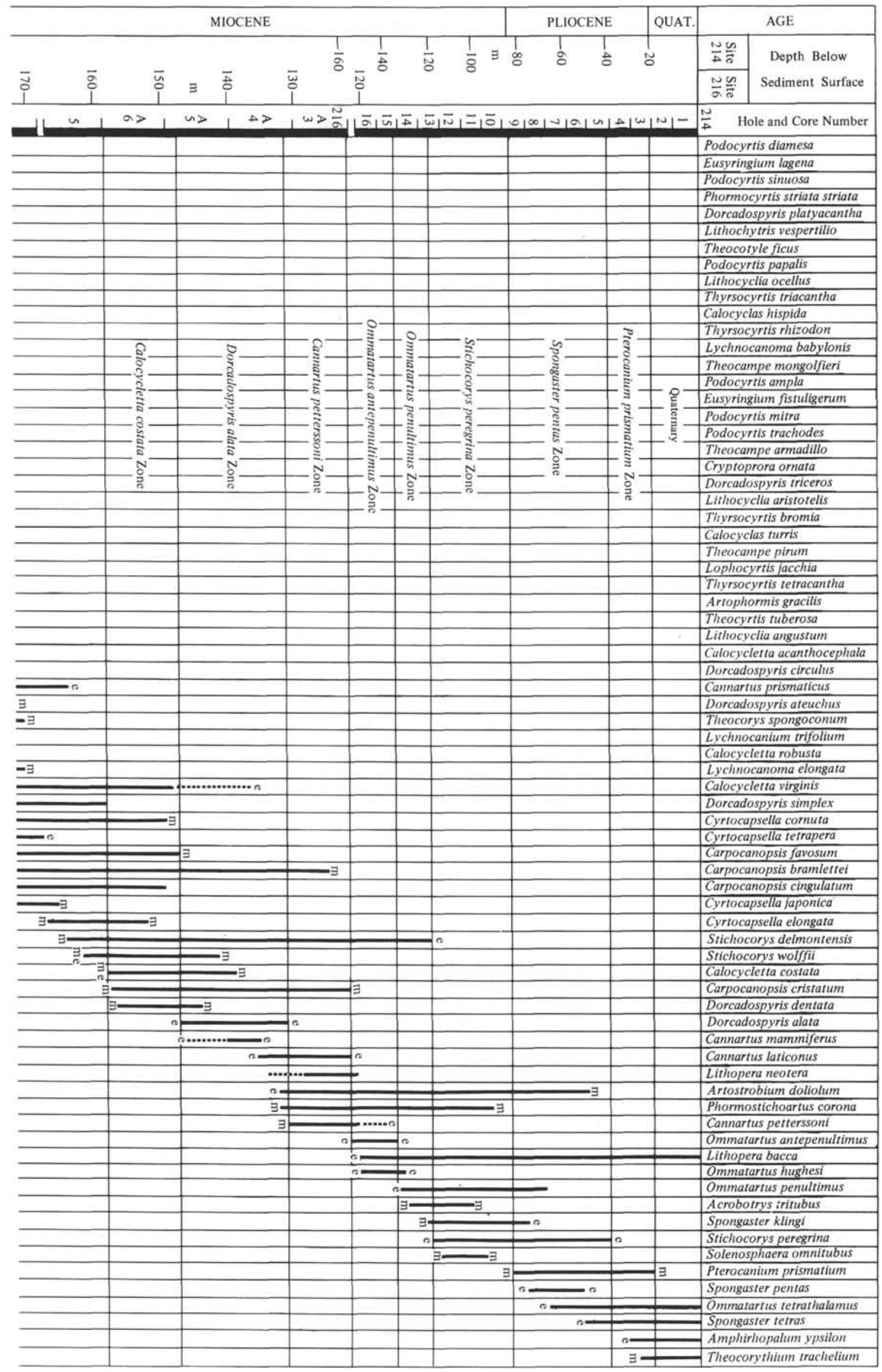

Figure 2. (Continued). 
those sites at which significant sequences were recovered (Sites 213 through 217); radiolarian occurrences at the remaining sites $(211,212,218)$ are indicated in the text. Cretaceous occurrences, found only at Site 216, are also described in the text.

The abundance of radiolarians in each sample is indicated in the tables as "very abundant" (A), "common" (C), "few" (F), "rare" (R), or "very rare" (+). Preservation of the specimens is indicated as "good" (G), "moderate" (M), or "poor" (P).

In the columns showing occurrences of individual species, the same relative abundance terms are used to indicate the proportion that a given species constitutes of the total radiolarian assemblage. A dash (-) indicates that the species was searched for but was not found. Occurrences believed to result from the reworking of older material into younger sediments, or from downward caving resulting in introduction of younger forms into older assemblages, are marked with an asterisk $(*)$.
Site 211

Radiolaria are common and well preserved in Cores 1 through 3 ( 0 to 66 meters). In Cores 4 through 6 (95 to 190 meters), Radiolaria are few to absent, and their-state of preservation is moderate to poor. Radiolaria are absent below Core 6 (190 meters).

Cores 1 and 2 are Quaternary, based on well-preserved specimens of Ommatartus tetrathalamus, Theocorythium trachelium, and Pterocanium praetextum, and the absence of Pterocanium prismatium. In Core 3, the presence of Pterocanium prismatium and Ommatartus tetrathalamus, and the absence of Stichocorys peregrina, indicates a Late Pliocene age (Pterocanium prismatium Zone).

Cores 4 through 6 contain scattered specimens of Cannartus laticonus, Stichocorys delmontensis, Cannartus petterssoni, Cyrtocapsella cornuta, Carpocanopsis bramlettei, Ommatartus antepenultimus, Lithopera renzae, Ommatartus hughesi, and other forms diagnostic of the

TABLE 1

Radiolarians at Site 213

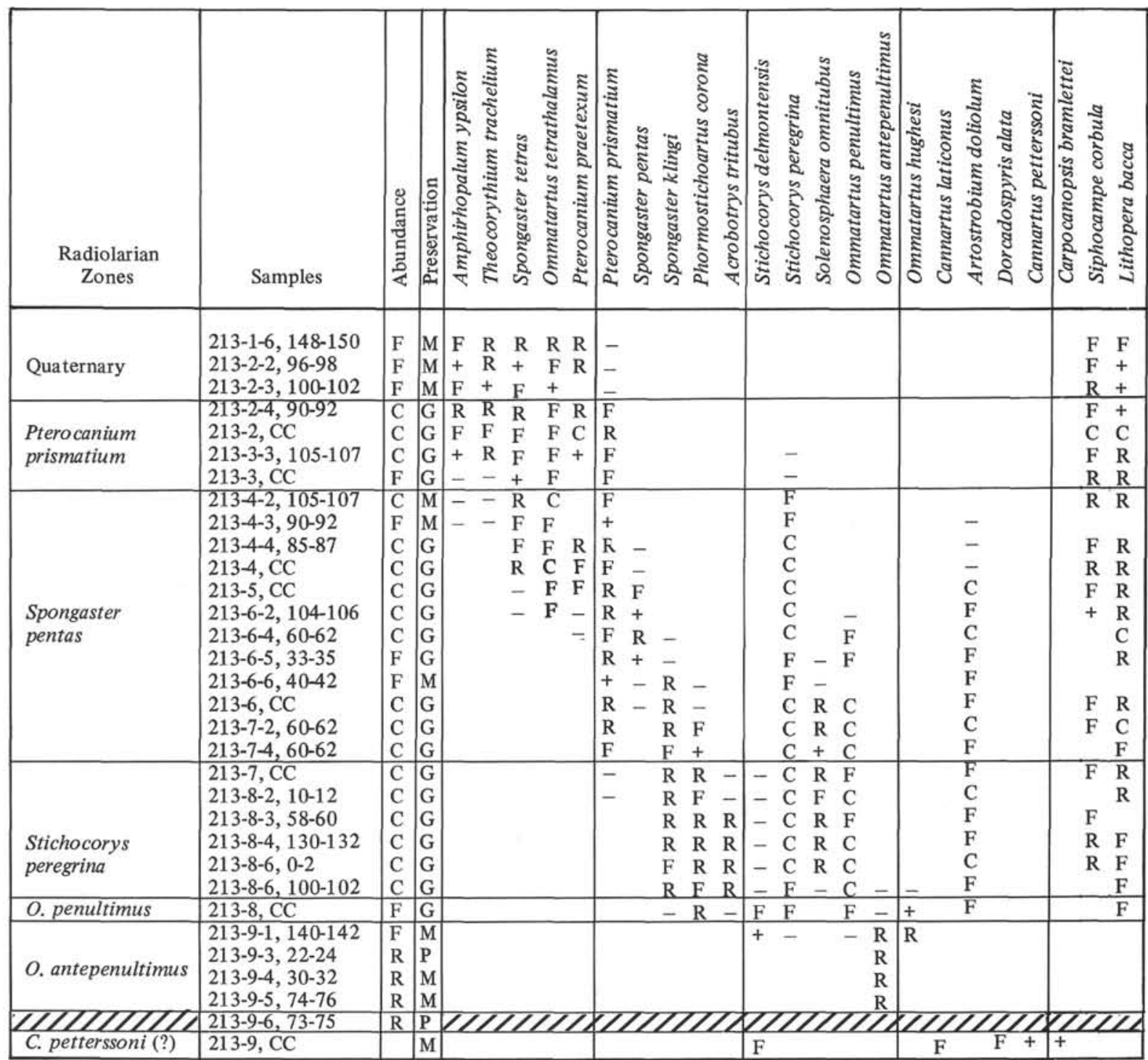

Note: See text for explanation of symbols. 
TABLE 2

Radiolarians at Site 214

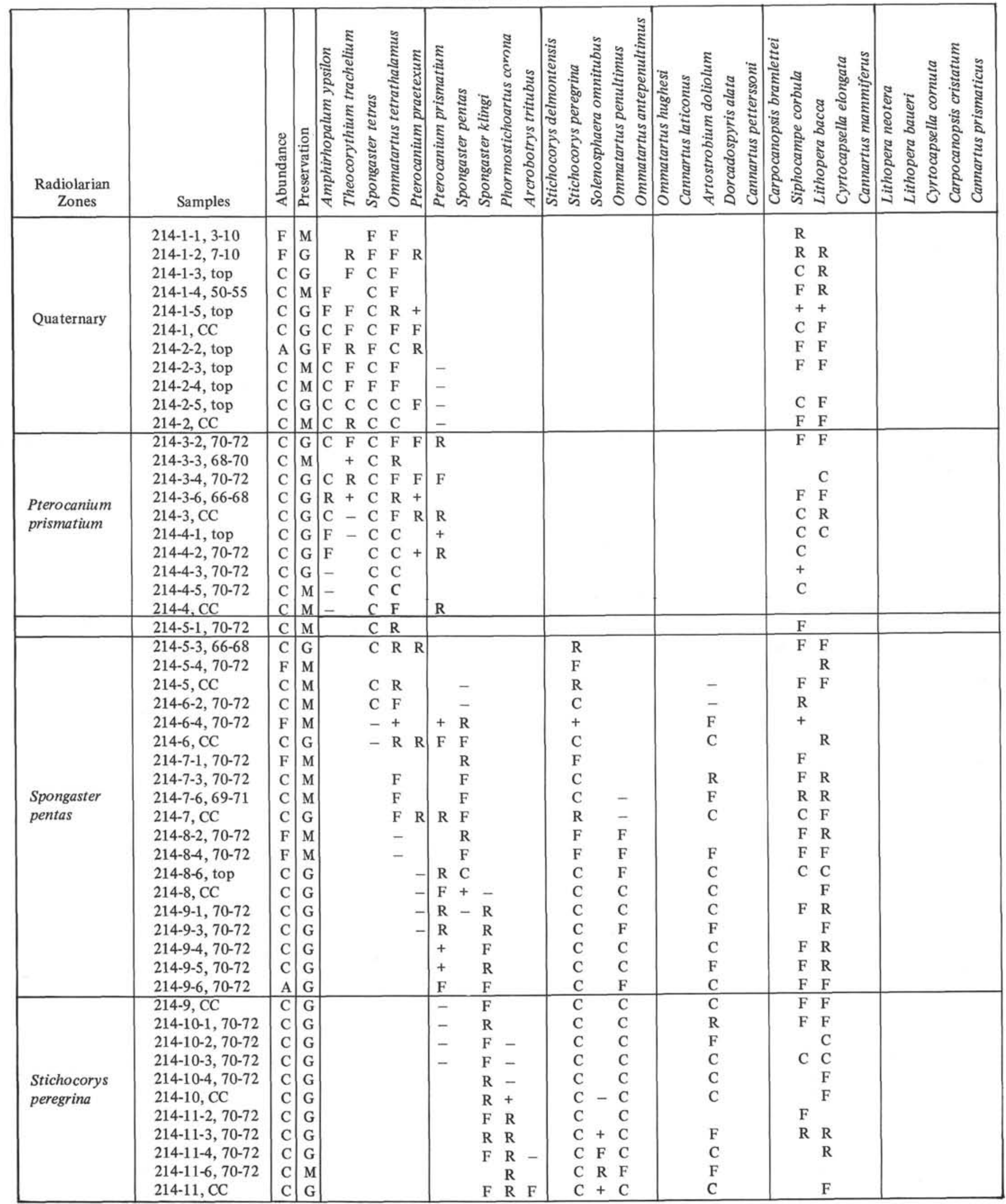


TABLE 2 - Continued

\begin{tabular}{|c|c|c|c|c|c|c|c|c|c|c|c|c|c|c|c|c|}
\hline $\begin{array}{c}\text { Radiolarian } \\
\text { Zones }\end{array}$ & Samples & 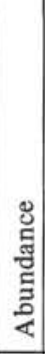 & 总 & 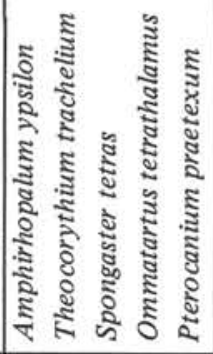 & 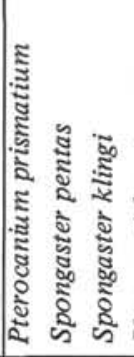 & 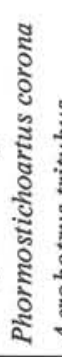 & 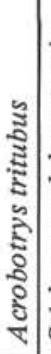 & 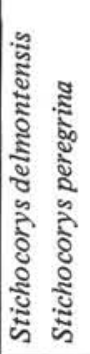 & 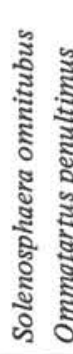 & 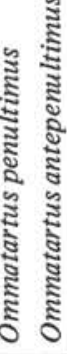 & 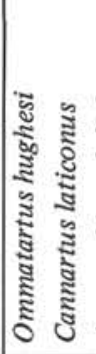 & 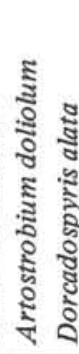 & 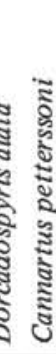 & 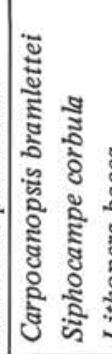 & 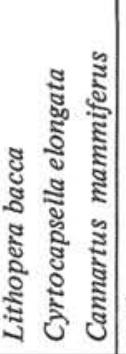 & 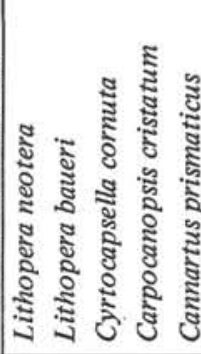 \\
\hline $\begin{array}{l}\text { Stichocorys } \\
\text { peregrina }\end{array}$ & $\begin{array}{l}4-12-1,80-82 \\
4-12-4, \text { top } \\
4-12, \text { CC } \\
4-13-3,70-72\end{array}$ & $\begin{array}{l}\mathrm{C} \\
\mathrm{C} \\
\mathrm{C} \\
\mathrm{C} \\
\end{array}$ & $\begin{array}{l}\text { G } \\
\text { G } \\
\text { G } \\
\text { G } \\
\end{array}$ & & $\begin{array}{l}\mathrm{R} \\
\mathrm{R} \\
\mathrm{F} \\
+ \\
\end{array}$ & $\begin{array}{l}+ \\
+ \\
\end{array}$ & $\mathrm{R}$ & $\begin{array}{l}\mathrm{C} \\
\mathrm{C} \\
\mathrm{F} \\
+\end{array}$ & $\begin{array}{ll}F & F \\
F & F \\
R & C \\
- & C \\
\end{array}$ & $\begin{array}{l}\mathrm{F} \\
\mathrm{F} \\
\mathrm{C} \\
\mathrm{C}\end{array}$ & & $\begin{array}{l}\mathrm{F} \\
\mathrm{F} \\
\mathrm{R}\end{array}$ & & $\begin{array}{l}\mathrm{R} \\
\mathrm{F} \\
\mathrm{R}\end{array}$ & C & \\
\hline $\begin{array}{l}\text { Ommatartus } \\
\text { penultimus }\end{array}$ & $\begin{array}{l}214-13-5,70-72 \\
214-13-6,70-72 \\
214-13, \text { CC } \\
214-14-5,70-72 \\
214-14, \text { CC }\end{array}$ & $\begin{array}{l}\mathrm{C} \\
\mathrm{C} \\
\mathrm{C} \\
\mathrm{A} \\
\mathrm{A}\end{array}$ & \begin{tabular}{|l} 
G \\
G \\
G \\
G \\
G \\
\end{tabular} & & $\begin{array}{l}\mathrm{R} \\
- \\
- \\
\end{array}$ & $\begin{array}{ll}\text { R } & + \\
\text { F } & \text { F } \\
\text { F } & \text { F } \\
\text { F } & \text { F } \\
\text { R } & \end{array}$ & \begin{tabular}{l|l}
+ & \\
$\mathrm{R}$ & \\
$\mathrm{R}$ & \\
$\mathrm{R}$ & \\
- &
\end{tabular} & $\begin{array}{l}\mathrm{C} \\
\mathrm{C} \\
\mathrm{A} \\
\mathrm{A} \\
\mathrm{A}\end{array}$ & $\begin{array}{r}-\mathrm{R} \\
-\mathrm{C} \\
\mathrm{C} \\
\mathrm{C} \\
\mathrm{C}\end{array}$ & $\begin{array}{l}\mathrm{R} \\
\mathrm{C} \\
\mathrm{C} \\
\mathrm{C}- \\
\mathrm{C}-\end{array}$ & - & $\begin{array}{l}\text { F } \\
\text { C } \\
\text { C } \\
\text { C } \\
\text { F }\end{array}$ & & $\begin{array}{r}5 \\
\mathrm{~F} \\
+\quad \mathrm{C} \\
\end{array}$ & $\begin{array}{l}\mathrm{C} \\
\mathrm{F} \\
\mathrm{C} \\
\mathrm{F}\end{array}$ & F \\
\hline $\begin{array}{l}\text { Ommatartus } \\
\text { antepenultimus }\end{array}$ & $\begin{array}{l}214-15-2,70-72 \\
214-15-3,80-82 \\
214-15-5,70-72 \\
214-15, \text { CC } \\
214-16-2,70-72 \\
214-16, \text { CC }\end{array}$ & \begin{tabular}{l|}
$\mathrm{C}$ \\
$\mathrm{C}$ \\
$\mathrm{C}$ \\
$\mathrm{C}$ \\
$\mathrm{F}$ \\
$\mathrm{C}$
\end{tabular} & $\begin{array}{l}\text { G } \\
\text { G } \\
\text { G } \\
\text { G } \\
\text { M } \\
\text { G }\end{array}$ & & & $\mathrm{F}$ & - & $\begin{array}{|ll|}\text { A } & \\
\text { F } & C^{*} \\
\text { C } & \\
\text { F } & \\
\text { F } & \\
\text { F } & \\
\end{array}$ & - & $\begin{array}{r}-F \\
-F \\
F \\
F \\
R \\
C\end{array}$ & $\begin{array}{l}\mathrm{C} \\
\mathrm{F} \\
\mathrm{F} \\
\mathrm{C}- \\
\mathrm{F}- \\
\mathrm{F}-\end{array}$ & $\begin{array}{l}\text { C } \\
\text { R } \\
\text { F } \\
\text { R } \\
\text { F } \\
\text { F }\end{array}$ & $\overline{\mathrm{F}}$ & & $\begin{array}{l}\text { F } \\
\text { R }\end{array}$ & $\begin{array}{l}F \\
F\end{array}$ \\
\hline $\begin{array}{l}\text { Cannartus } \\
\text { petterssoni }\end{array}$ & $\begin{array}{l}214-17-1,70-72 \\
214-17-2,70-72 \\
214-17-3,70-72 \\
214-17-5,70-72 \\
214-17, \mathrm{CC} \\
214-18-1,68-70 \\
214-18-2,70-72\end{array}$ & \begin{tabular}{l|}
$\mathrm{C}$ \\
$\mathrm{F}$ \\
$\mathrm{F}$ \\
$\mathrm{F}$ \\
$\mathrm{F}$ \\
$\mathrm{C}$ \\
$\mathrm{C}$
\end{tabular} & $\begin{array}{l}\mathrm{G} \\
\mathrm{M} \\
\mathrm{M} \\
\mathrm{M} \\
\mathrm{M} \\
\mathrm{M} \\
\mathrm{M}\end{array}$ & & & & & $\begin{array}{l}\mathrm{F} \\
\mathrm{R}\end{array}$ & . & - & $\begin{array}{r}-\mathrm{C} \\
-\mathrm{R} \\
\mathrm{F} \\
\mathrm{F} \\
\mathrm{C} \\
\mathrm{C} \\
\mathrm{C}\end{array}$ & $\mathrm{R}$ & $\begin{array}{l}\text { C } \\
\text { R } \\
\text { F } \\
\text { F } \\
\text { C } \\
\text { C } \\
\text { F }\end{array}$ & $\begin{array}{l}- \\
- \\
R \\
F\end{array}$ & - & \\
\hline $\begin{array}{l}\text { Dorcadospyris } \\
\text { alata }\end{array}$ & $\begin{array}{l}214-18-3,70-72 \\
214-18-5,70-72 \\
214-18, \text { CC } \\
214-19-3,70-72 \\
214-19, \text { CC } \\
214-20-1,70-72 \\
214-20, \text { CC }\end{array}$ & \begin{tabular}{l|}
$\mathrm{C}$ \\
$\mathrm{R}$ \\
$\mathrm{F}$ \\
$\mathrm{C}$ \\
$\mathrm{F}$ \\
$\mathrm{F}$ \\
$\mathrm{C}$
\end{tabular} & \begin{tabular}{|l|}
$\mathrm{M}$ \\
$\mathrm{P}$ \\
$\mathrm{M}$ \\
$\mathrm{M}$ \\
$\mathrm{M}$ \\
$\mathrm{M}$ \\
$\mathrm{M}$
\end{tabular} & & & & & & & & $\begin{array}{l}\mathrm{C} \\
+ \\
\mathrm{C} \\
\mathrm{C} \\
\mathrm{C} \\
\mathrm{C} \\
-\end{array}$ & $\begin{array}{l}\text { F } \\
\text { R } \\
\text { F } \\
\text { F } \\
\text { F }\end{array}$ & - & $\begin{array}{l}\mathrm{R} \\
\mathrm{R} \\
\mathrm{F}\end{array}$ & F F & R R $+F$ \\
\hline
\end{tabular}

Note: See text for explanation of symbols.

middle to late Miocene. However, the presence of scattered specimens of Sphaeroidinella sp. in the underlying Cores 7 through 9 (see report on foraminifera) suggests that Cores 4 through 6 may be Pliocene in age and that the Miocene forms are reworked. Hence, a Pliocene age is tentatively assigned to cores 4 through 6 . The absence of diagnostic Pliocene species from the radiolarian assemblages in these cores remains enigmatic.

\section{Site 212}

At Site 212, poorly preserved Radiolaria are present in the core catcher samples of Core 1 (depth 9.5 meters) and Core 3 (depth 50.5 meters). Radiolaria are absent between the bottom of Core 4 and Core 19, Section 2 (60 to 334 meters). Moderately preserved to well-preserved Radiolaria of middle Eocene age are present between the bottom of Core 19 and Core 23, Section 3 (335 to 368 meters). Radiolaria are absent in the interval between Core 23,
Section 5 and the volcanic rock encountered at the bottom of the hole ( 370 to 518 meters).

The nannofossil ooze present in Cores 1 and 3 contains sparse, poorly preserved fragments of Radiolaria. Species encountered include Ommatartus tetrathalamus, Euchitonia elegans, Lithopera bacca, and Theocorythium trachelium and are consistent with the late Miocene to Pliocene age assigned on the basis of the nannofossil assemblages present in these cores.

A portion of the middle Eocene chalk unit, between the bottom of Core 19 and Core 23, Section 3, contains a well-preserved assemblage of diatoms and radiolarians. The radiolarian assemblage is characterized by rare to common occurrences of the following species (see Plates 2 and 3): Theocampe mongolfieri, Theocampe amphora group, Theocotyle cryptocephala cryptocephala, Lamptonium fabaeforme fabaeforme, Phormocyrtis striata striata, Phormocyrtis striata exquisita, Giraffospyris cyrillium, Lophocyrtis biaurita, Lychnocanoma babylonis group, and 
TABLE 3

Radiolarians at Site 215

\begin{tabular}{|c|c|c|c|c|c|c|c|c|c|c|c|c|c|}
\hline Radiolarian Zones & Samples & 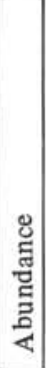 & 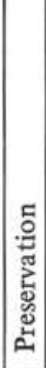 & 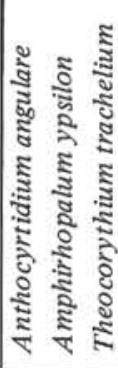 & 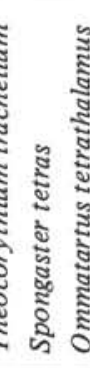 & 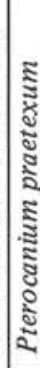 & 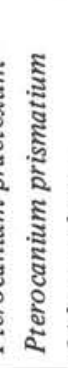 & 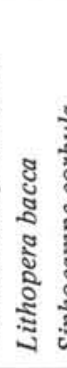 & 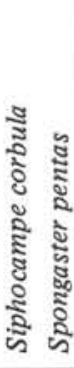 & 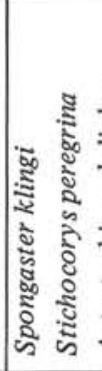 & 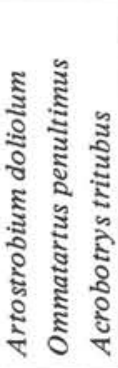 & 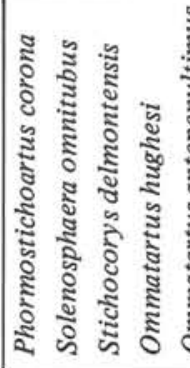 & हू \\
\hline Quaternary & $\begin{array}{l}215-1-1,1-3 \\
215-1-1,46-48 \\
215-1-4,30-32 \\
215-1-4,130-132 \\
\end{array}$ & $\begin{array}{l}\mathrm{C} \\
\mathrm{C} \\
\mathrm{C} \\
\mathrm{C} \\
\end{array}$ & $\begin{array}{l}G \\
G \\
G \\
G \\
\end{array}$ & $\begin{array}{lll}+ & F & F \\
+ & R & C \\
R & F & C \\
R & F & F \\
\end{array}$ & $\begin{array}{ll}\mathrm{F} & \mathrm{C} \\
\mathrm{F} & \mathrm{C} \\
\mathrm{F} & \mathrm{F} \\
\mathrm{F} & \mathrm{F}\end{array}$ & $\mathbf{R}$ & $\begin{array}{l}- \\
- \\
- \\
-\end{array}$ & $\begin{array}{l}\mathrm{C} \\
\mathrm{F} \\
\mathrm{C} \\
\mathrm{R} \\
\end{array}$ & $\begin{array}{l}\mathrm{C} \\
\mathrm{C} \\
\mathrm{F} \\
\mathrm{F}\end{array}$ & & & & \\
\hline $\begin{array}{c}\text { Pterocanium } \\
\text { prismatium }\end{array}$ & $\begin{array}{l}215-1-5,70-72 \\
215-1-6,39-41 \\
215-1, C C \\
215-2-1,53-55\end{array}$ & \begin{tabular}{l|}
$\mathrm{C}$ \\
$\mathrm{C}$ \\
$\mathrm{C}$ \\
$\mathrm{C}$ \\
\end{tabular} & \begin{tabular}{|l|}
$G$ \\
$G$ \\
G \\
M \\
\end{tabular} & \begin{tabular}{|rr}
$R$ & $F$ \\
$R$ & $R$ \\
$F$ & $R$ \\
$R$ & - \\
\end{tabular} & 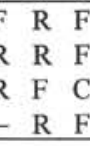 & $F$ & $\begin{array}{l}\mathrm{F} \\
\mathrm{F} \\
\mathrm{R} \\
\mathrm{R}\end{array}$ & & $\begin{array}{l}\text { C } \\
\mathrm{C} \\
\mathrm{C} \\
\mathrm{F}\end{array}$ & - & & & \\
\hline $\begin{array}{l}\text { Spongaster } \\
\text { pentas }\end{array}$ & $\begin{array}{l}215-2, \mathrm{CC} \\
215-3-1,69-71 \\
215-3-3,70-72 \\
215-3, \mathrm{CC} \\
215-4-1,11-13 \\
215-4-1,120-122 \\
215-4-2,70-72 \\
215-4-3,70-72 \\
215-4-4,70-72 \\
215-4-5,70-72 \\
215-4-6,70-72 \\
215-4, \mathrm{CC} \\
215-5-1,70-72 \\
215-5-3,70-72 \\
\end{array}$ & $\begin{array}{l}\mathrm{C} \\
\mathrm{C} \\
\mathrm{F} \\
\mathrm{C} \\
\mathrm{C} \\
\mathrm{C} \\
\mathrm{C} \\
\mathrm{C} \\
\mathrm{C} \\
\mathrm{C} \\
\mathrm{C} \\
\mathrm{C} \\
\mathrm{C} \\
\mathrm{C}\end{array}$ & $\begin{array}{l}G \\
\text { G } \\
\text { M } \\
\text { G } \\
\text { G } \\
\text { G } \\
\text { G } \\
\text { G } \\
\text { G } \\
\text { G } \\
\text { G } \\
\text { G } \\
\text { G } \\
\text { G }\end{array}$ & $\begin{array}{l}F- \\
-- \\
- \\
-\end{array}$ & $\begin{array}{rl}-\mathrm{R} & \mathrm{F} \\
-\mathrm{F} & \mathrm{F} \\
\mathrm{R} & \mathrm{R} \\
\mathrm{F} & \mathrm{F} \\
- & \mathrm{C} \\
& \mathrm{C} \\
& \mathrm{F} \\
& \mathrm{R} \\
& \\
\end{array}$ & $\begin{array}{l}\mathrm{R} \\
\mathrm{R}\end{array}$ & $\begin{array}{l}F \\
F \\
F \\
F \\
R \\
F \\
F \\
F \\
F \\
C \\
R\end{array}$ & $\begin{array}{ll}\mathrm{F} & \\
\mathrm{R} & \mathrm{I} \\
& \\
\mathrm{F} & \mathrm{I} \\
\mathrm{C} & \mathrm{I} \\
\mathrm{C} & \\
\mathrm{C} & \\
\mathrm{C} & \mathrm{F} \\
\mathrm{F} & \\
\mathrm{F} & \\
\mathrm{F} & \\
\end{array}$ & $\begin{array}{ll}\mathrm{C} & \\
\mathrm{R} & - \\
& - \\
\mathrm{C} & - \\
\mathrm{F} & \mathrm{R} \\
\mathrm{F} & \mathrm{R} \\
& \mathrm{R} \\
& \mathrm{R} \\
\mathrm{C} & - \\
\mathrm{C} & - \\
& - \\
\mathrm{C} & \\
\mathrm{F} & \end{array}$ & $\begin{array}{rr} & F \\
& C \\
& F \\
& C \\
& C \\
& C \\
- & C \\
- & C \\
R & C \\
R & C \\
R & C \\
R & C \\
R & C \\
R & C \\
\end{array}$ & 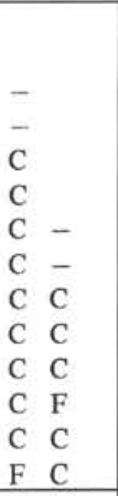 & & \\
\hline $\begin{array}{l}\text { Stichocorys } \\
\text { peregrina }\end{array}$ & $\begin{array}{l}215-5, \mathrm{CC} \\
215-6-1,110-112 \\
215-6-3,70-72 \\
215-6, \mathrm{CC} \\
215-7-1,130-132 \\
215-7-2,70-72 \\
215-7, \mathrm{CC}\end{array}$ & $\begin{array}{l}\mathrm{C} \\
\mathrm{C} \\
\mathrm{F} \\
\mathrm{C} \\
\mathrm{C} \\
\mathrm{F} \\
\mathrm{C}\end{array}$ & \begin{tabular}{l|}
$G$ \\
$G$ \\
$M$ \\
$G$ \\
$G$ \\
$P$ \\
$G$
\end{tabular} & & & & $\begin{array}{l}- \\
- \\
-\end{array}$ & $\begin{array}{l}\mathrm{F} \\
\mathrm{F} \\
\mathrm{R} \\
\mathrm{R} \\
\mathrm{C}\end{array}$ & $\begin{array}{l}\mathrm{C} \\
+ \\
\mathrm{F} \\
\mathrm{R} \\
\mathrm{F}\end{array}$ & $\begin{array}{ll}\mathrm{F} & \mathrm{C} \\
\mathrm{R} & \mathrm{C} \\
& \mathrm{F} \\
\mathrm{R} & \mathrm{C} \\
\mathrm{F} & \mathrm{C} \\
& \\
\mathrm{R} & \mathrm{C} \\
\end{array}$ & $\begin{array}{lll}\mathrm{C} & \mathrm{F} & \\
\mathrm{C} & \mathrm{F} & - \\
& \mathrm{R} & + \\
\mathrm{C} & \mathrm{C} & \mathrm{F} \\
\mathrm{C} & \mathrm{C} & \\
\mathrm{C} & \mathrm{C} & \mathrm{R}\end{array}$ & $\begin{array}{ll}-\bar{R} & - \\
\mathrm{R} & \mathrm{R} \\
\mathrm{F} & \mathrm{R} \\
\mathrm{F} & \mathrm{R} \\
\mathrm{F} & + \\
\end{array}$ & \\
\hline $\begin{array}{c}\text { Ommatartus } \\
\text { antepenultimus }\end{array}$ & $\begin{array}{l}215-8-1,90-92 \\
215-8-2,8-10 \\
215-8-2,78-80 \\
215-8-3,19-21 \\
215-8-3,78-80 \\
215-8-4,15-17 \\
215-8-4,118-120 \\
215-8-5,20-22 \\
215-8-5,78-80\end{array}$ & $\begin{array}{l}\mathrm{F} \\
\mathrm{F} \\
\mathrm{C} \\
\mathrm{F} \\
\mathrm{F} \\
+ \\
\mathrm{R} \\
+ \\
+\end{array}$ & $\begin{array}{l}\mathrm{M} \\
\mathrm{M} \\
\mathrm{M} \\
\mathrm{P} \\
\mathrm{M} \\
\mathrm{P} \\
\mathrm{P} \\
\mathrm{P} \\
\mathrm{P}\end{array}$ & & & & & + & + & $\begin{array}{r}\mathrm{C}^{*} \\
\mathrm{R} * \mathrm{R}^{*} \\
+* \\
+ \\
+*\end{array}$ & 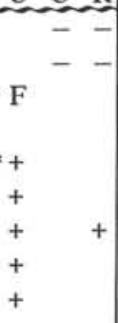 & 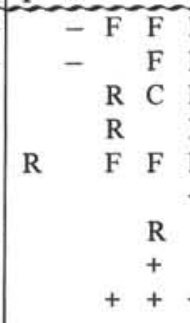 & $\begin{array}{l}\text { R } \\
\mathrm{R} \\
\mathrm{F} \\
\mathrm{R} \\
\mathrm{F} \\
+ \\
\\
+\end{array}$ \\
\hline
\end{tabular}

Dorcadospyris sp. $\mathrm{cf} D$. platyacantha. This assemblage is of early middle Eocene age, probably within the Theocampe mongolfieri Zone (Foreman, 1973). However, the nannofossil assemblages within these cores suggest a slightly younger age, probably the Chiasmolithus grandis Zone of late middle Eocene age.

The rather abrupt appearance (at 368 meters) and disappearance (at 335 meters) of the siliceous material within the Eocene chalk unit, together with the slight discrepancy between the age assigned on the basis of nannofossils and that assigned by radiolarians, suggest that the siliceous component of the sediment may be reworked. Thus, even though the radiolarian assemblage between 335 meters and 368 meters appears to be earliest middle Eocene in age, it may have been redeposited at its present location at a later time.

\section{Site 213}

Radiolaria ranging in age from Quaternary to middle Miocene are present in Cores 1 through 10 (0 to 94.5 meters) at Site 213 (Table 1). In Cores 1 through 8, Radiolaria are common and well preserved. In Cores 9 and 
TABLE 4A

Radiolarians at Site 216

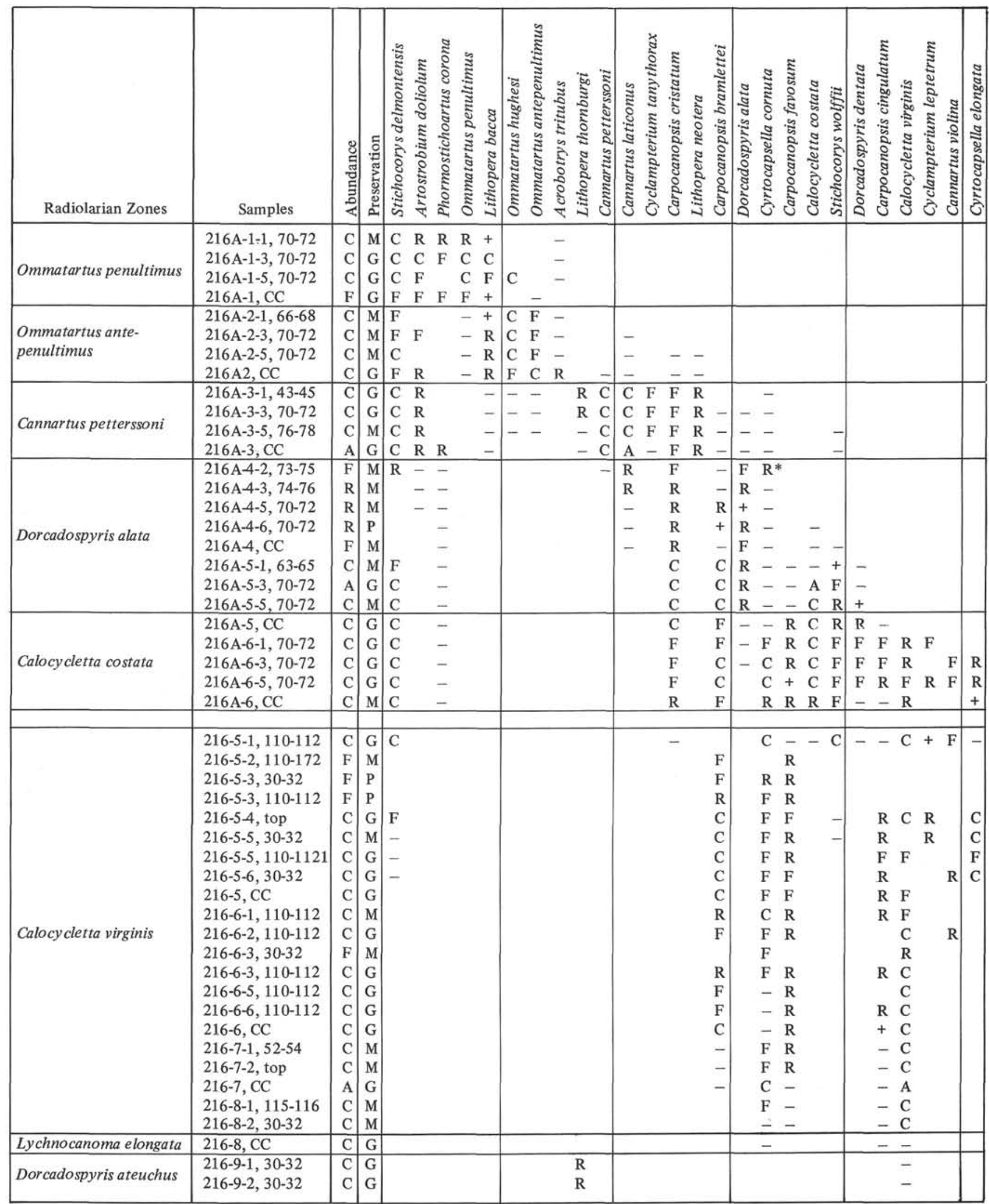

Note: See text for explanation of symbols. 
TABLE 4B

Radiolarians at Site $\mathbf{2 1 6}$

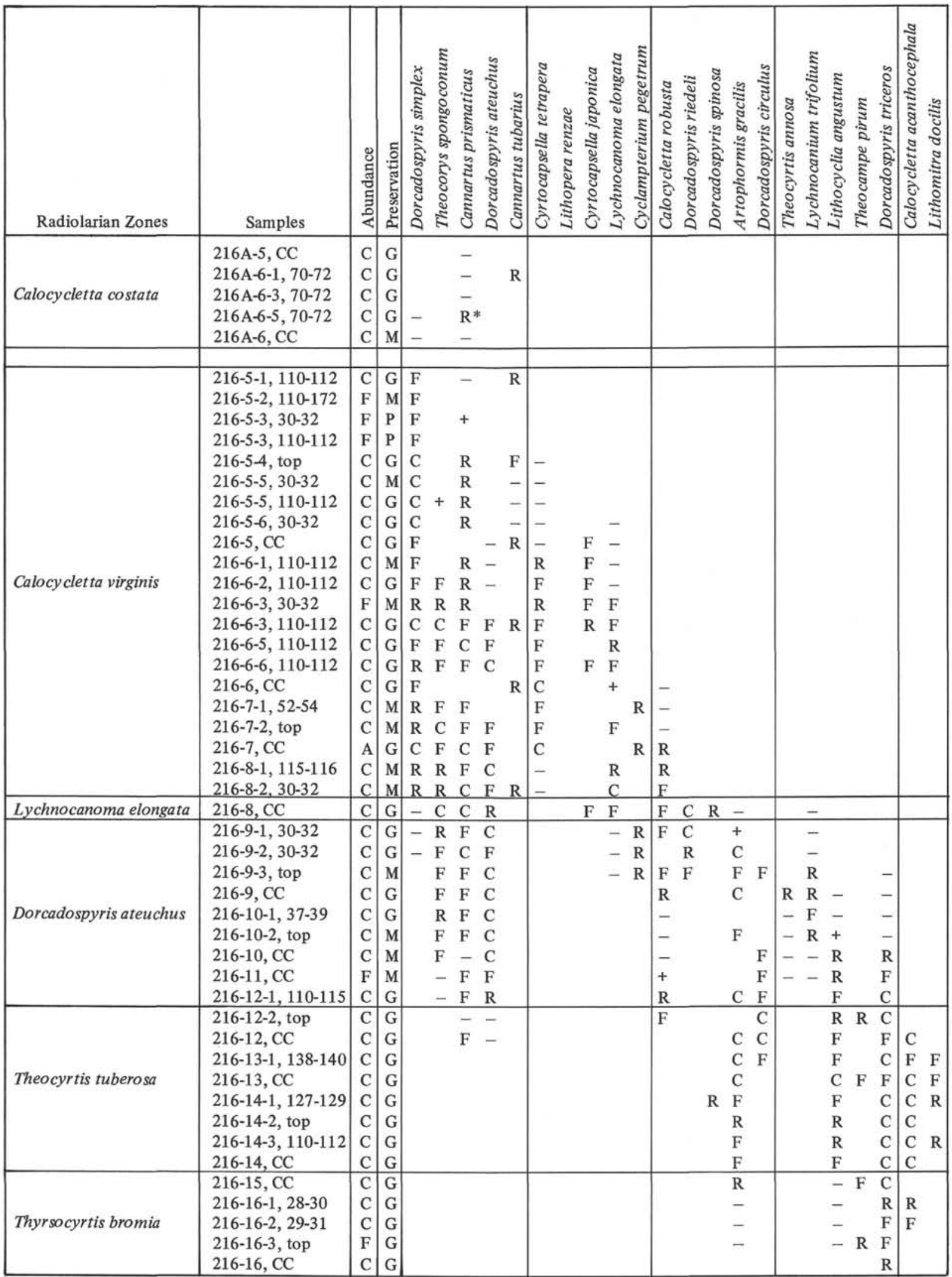

Note: See text for explanation of symbols. 
TABLE 4C

Radiolarians at Site 216

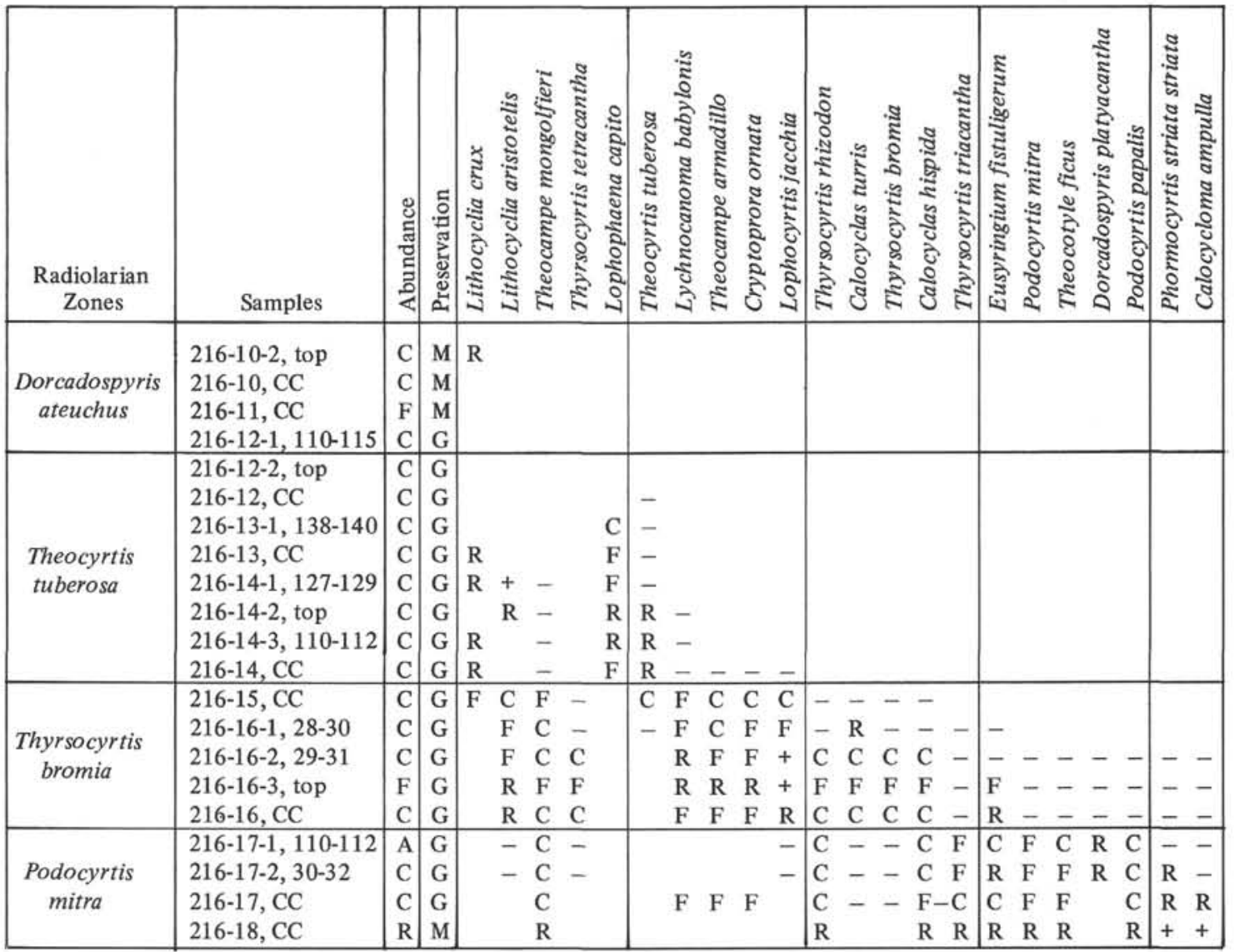

Note: See text for explanation of symbols.

10, Radiolaria are increasingly more corroded downward, and the orosphaerids and collosphaerids are the predominant forms present.

The following faunal boundaries can be recognized within the siliceous ooze section of the cores:

The base of the Quaternary is between 13 and 14.5 meters (between Samples 213-2-3, 100-102 cm and $213-2-4,90-92 \mathrm{~cm})$. The base of the Pterocanium prismatium Zone is between 18 and 30.5 meters (between Samples 213-3, CC and 213-4-2, 105-107 cm). The base of the Spongaster pentas Zone is between 62 and 66 meters (between Samples 213-7-4, 60-62 cm and 213-7, CC). The base of Stichocorys peregrina Zone is between 75 and 75.5 meters (between Samples 213-8-6, 100-102 cm and 213-8, CC).

The Ommatartus penultimus Zone is represented at 75.5 meters (Sample 213-8, CC). Material between 77 and 94 meters (between Samples 213-9-1, 140-142 cm and $213-9-6,73-75 \mathrm{~cm}$ ) is within the Ommatartus antepenultimus Zone. The material at 85 meters (sample 213-9, CC) lies within the lower Cannartus petterssoni or upper Dorcadospyris alata Zone. Radiolaria occur only in unidentifiable fragments or are absent entirely below 85.5 meters (Sample 213-10-1, 70-72 cm). At all levels at which Radiolaria are present, there is no indication of reworking of older material.

\section{Site 214}

Radiolaria at Site 214 are common to abundant and well preserved within Cores 1 through 20 (0 to 190.5 meters), which range in age from Quaternary to middle Miocene (Table 2). In the lower part of this interval (Cores 17 through 20), the radiolarian assemblages show strong effects of corrosion; species are only moderately preserved. Below Core 20 the radiolarian assemblage disappears entirely. No identifiable Radiolaria were encountered in the underlying sediment although trace amounts of siliceous debris are present in some samples.

The Quaternary radiolarian assemblage appears to contain elements representative of both low latitudes and middle latitudes. Low-latitude species present include Euchitonia elegans, Spongaster tetras tetras, Ommatartus tetrathalamus, and Theocorythium trachelium trachelium. Mid-latitude species include Pterocanium praetextumeucolpum, Eucyrtidium acuminatum, and Lamprocyclas maritalis maritalis.

The following radiolarian zonal boundaries can be recognized within the pre-Quaternary portion of the cores at Site 214:

The base of the Quaternary lies between 19 and 21 meters (between Samples 214-2, CC and 214-3-2, 70-72 $\mathrm{cm})$. The base of the Pterocanium prismatium Zone lies 
TABLE 5

Radiolarians at Site 217

\begin{tabular}{|c|c|c|c|c|c|c|c|c|c|}
\hline $\begin{array}{c}\text { Radiolarian } \\
\text { Zones }\end{array}$ & Samples & 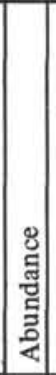 & & 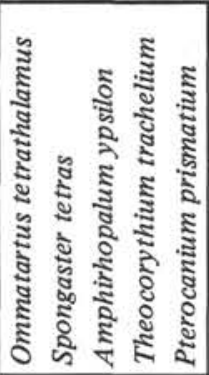 & 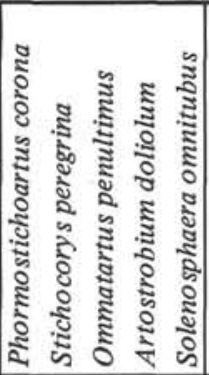 & 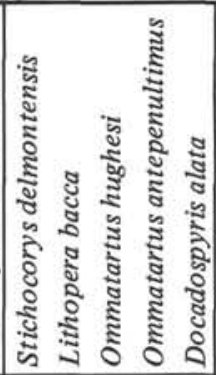 & 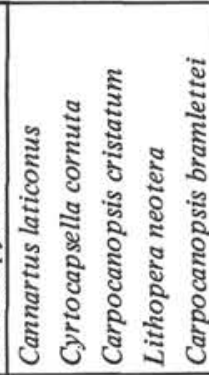 & 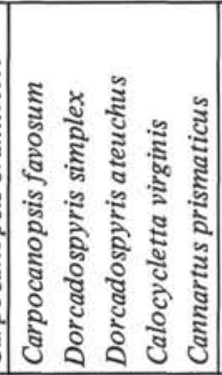 & 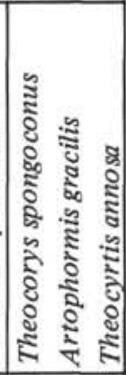 \\
\hline Quaternary & $\begin{array}{l}217-1-1,70-72 \\
217-1-4, \text { top } \\
217-1, \mathrm{CC}\end{array}$ & \begin{tabular}{|l|}
$\mathrm{C}$ \\
$\mathrm{C}$ \\
$\mathrm{F}$
\end{tabular} & $\begin{array}{l}\mathrm{G} \\
\mathrm{G} \\
\mathrm{R}\end{array}$ & $\begin{array}{lllll}\mathrm{F} & \mathrm{R} & \mathrm{R} & \mathrm{F} & - \\
\mathrm{F} & \mathrm{R} & \mathrm{R} & \mathrm{R} & - \\
+ & \mathrm{F} & - & \\
\end{array}$ & $\begin{array}{l}- \\
- \\
-\end{array}$ & $\mathrm{R}$ & & & \\
\hline S. peregrina & $217-3-1,70-72$ & A & $G \mid$ & $--2-3-1$ & $C A \Delta C D$ & $-F--$ & & & \\
\hline O. penultimus & $217-3, \mathrm{CC}$ & \begin{tabular}{|l|}
$\mathrm{A}$ \\
$\mathrm{C}$
\end{tabular} & \begin{tabular}{|l|l}
$G$ \\
$G$ \\
\end{tabular} & $-\ldots-\cdots$ & $\begin{array}{lllll}C & A & A & C & -1 \\
F & - & C & C & C \\
\end{array}$ & $\begin{array}{l}-F-- \\
F F-\cdots\end{array}$ & & & \\
\hline O. antepenultimus & $217-4, C C$ & C & G & & $F-F$ & C R C C & & & \\
\hline D. alata & $\begin{array}{l}217-5-1,123-125 \\
217-5, \mathrm{CC}\end{array}$ & \begin{tabular}{l|} 
\\
C \\
\end{tabular} & \begin{tabular}{l|}
$\mathrm{M}$ \\
$\mathrm{M}$
\end{tabular} & & & \begin{tabular}{|l|}
$\mathrm{F}--\mathrm{R}$ \\
$\mathrm{R}---\mathrm{F}$
\end{tabular} & $\begin{array}{llllll}\text { C } & \text { R } & \text { C } & & - \\
\text { C } & \text { R } & \text { R } & \text { R } & -\end{array}$ & - & \\
\hline C. virginis & $\begin{array}{l}217-6-1,70-72 \\
217-6, \mathrm{CC}\end{array}$ & \begin{tabular}{|l|} 
C \\
C
\end{tabular} & $\begin{array}{l}\mathrm{M} \\
\mathrm{G}\end{array}$ & & & & $\begin{array}{lll}R & F & R \\
R & & \\
R\end{array}$ & $\begin{array}{|lllll|}\mathrm{R} & \mathrm{F} & \mathrm{F} & \mathrm{C} & \mathrm{R} \\
- & \mathrm{R} & \mathrm{F} & \mathrm{A} & \mathrm{F} \\
\end{array}$ & $\overline{\mathrm{F}}$ \\
\hline D. ateuchus & $\begin{array}{l}217-7-1,140-142 \\
217-7-3,70-72 \\
217-7-5,68-70 \\
217-7, \mathrm{CC} \\
\end{array}$ & \begin{tabular}{|l|}
$\mathrm{C}$ \\
$\mathrm{C}$ \\
$\mathrm{C}$ \\
$\mathrm{C}$ \\
\end{tabular} & \begin{tabular}{l|l}
$G$ \\
$G$ \\
$G$ \\
$M$ \\
\end{tabular} & & & & - & $\begin{array}{r}-F-F \\
C-F \\
F-R \\
R-F\end{array}$ & $\begin{array}{|lll|} & C & F \\
F & C & \\
F & C & F \\
F & R & R \\
\end{array}$ \\
\hline T. tuberosa & $\begin{array}{l}217-8-1,73-75 \\
217-8-6,148-150 \\
217-9-1,70-72 \\
217-9-3,68-70\end{array}$ & \begin{tabular}{l|}
$c$ \\
$c$ \\
$c$ \\
$c$
\end{tabular} & \begin{tabular}{|l|}
$G$ \\
$G$ \\
$G$ \\
$G$
\end{tabular} & & & & & $\begin{array}{ll}- & F \\
- & D F\end{array}$ & $\begin{array}{l}\mathrm{C} \\
\mathrm{C} \\
\mathrm{C} \\
\mathrm{C}\end{array}$ \\
\hline T. bromia & $\begin{array}{l}217-9-5,66-68 \\
217-9, \text { CC } \\
\end{array}$ & $\begin{array}{l}\mathrm{C} \\
\mathrm{C}\end{array}$ & \begin{tabular}{|l|}
$G$ \\
$G$ \\
\end{tabular} & & & & & & \\
\hline P. mitra & $\begin{array}{l}217-10-1,108-110 \\
217-10-2,68-70 \\
217-10-3, \text { top }\end{array}$ & \begin{tabular}{|l|}
$\mathbf{C}$ \\
$\mathrm{C}$ \\
$\mathrm{C}$
\end{tabular} & \begin{tabular}{l|}
$G$ \\
$G$ \\
$G$ \\
\end{tabular} & & & & & & \\
\hline P. ampla & $\begin{array}{l}217-10-4,70-72 \\
217-10-6,68-70 \\
\end{array}$ & \begin{tabular}{|l|}
$\mathrm{c}$ \\
$\mathrm{c}$
\end{tabular} & \begin{tabular}{|l|}
$G$ \\
$G$
\end{tabular} & & & & & & \\
\hline T. triacantha & $217-10, \mathrm{CC}$ & $\mathrm{A}$ & G & & & & & & \\
\hline
\end{tabular}

between 38 and 42 meters (between Samples 214-4, CC and 214-5-3, 66-68 cm). The base of the Spongaster pentas Zone lies between 84.5 and 85.5 meters (between Samples $214-9-6,70-72 \mathrm{~cm}$ and $214-9, \mathrm{CC})$. The base of the Stichocorys peregrina Zone lies between 118 and 121 meters (between Samples 214-13-3, 70-72 cm and $214-13-5,70-72 \mathrm{~cm})$. The base of the Ommatartus penultimus Zone lies between 152.5 and 153 meters (between Samples 214-16, CC and 214-17-1, 70-72 cm). The base of the Cannartus petterssoni Zone lies between 162 and 170.5 meters (between Samples 214-18-2, 70-72 $\mathrm{cm}$ and 214-18-3, 70-72 cm). The base of the Dorcadospyris alata Zone occurs in the nonsiliceous interval, probably not far below 190.5 meters (Sample $214-20$, CC).
All radiolarian assemblages appear to contain contemporaneous species, with no indication of reworking of species from older sediment.

At Site 214, as well as at the preceding site (213), there is a transition zone between the cores in which Radiolaria are abundant and well preserved (Cores 1 through 16) and that in which they are absent (below Core 20). In Cores 17 through 20, which lie within the middle Miocene (Cannartus petterssoni Zone and Dorcadospyris alata Zone), the radiolarian assemblages are much less diverse than in the overlying material. Only two or three diagnostic species are present, and certain families of radiolaria (collosphaerids and orosphaerids) dominate the assemblages. It is suggested that these families are present in abundance within these cores because they may be 
TABLE 5 - Continued

\begin{tabular}{|c|c|c|c|c|c|c|c|c|c|}
\hline Radiolarian Zones & Samples & 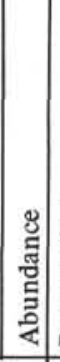 & . & 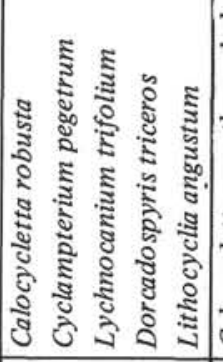 & 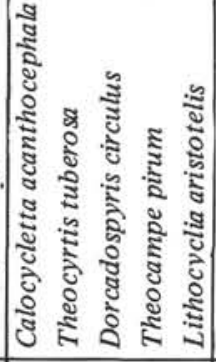 & 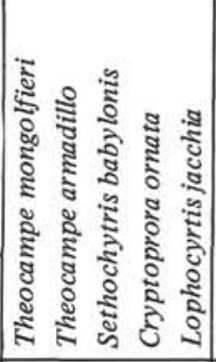 & 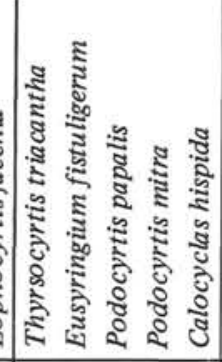 & 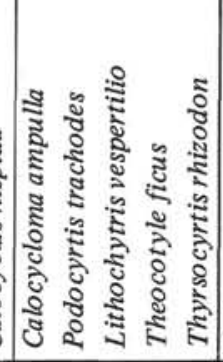 & 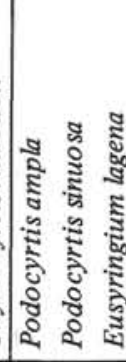 \\
\hline Quaternary & \begin{tabular}{|l}
$217-1-1,70-72$ \\
$217-1-4$, top \\
$217-1$, CC \\
\end{tabular} & $\mid \begin{array}{l}\mathrm{C} \\
\mathrm{C} \\
\mathrm{A}\end{array}$ & $\begin{array}{l}G \\
G \\
G \\
\end{array}$ & & & & & & \\
\hline S. peregrina & $217-3-1,70-72$ & A & G & & & & & & \\
\hline O. penultimus & $217-3, \mathrm{CC}$ & C & G & & & & & & \\
\hline O. antepenultimus & $217-4, \mathrm{CC}$ & C & G & & t & & & & \\
\hline & & & & & & & & & \\
\hline D. alata & $\begin{array}{l}217-5-1,123-125 \\
217-5, \mathrm{CC}\end{array}$ & \begin{tabular}{l|l}
$\mathrm{C}$ \\
$\mathrm{C}$
\end{tabular} & \begin{tabular}{|l|}
$\mathrm{M}$ \\
$\mathrm{M}$
\end{tabular} & & & & & & \\
\hline C. virginis & $\begin{array}{l}217-6-1,70-72 \\
217-6, \mathrm{CC}\end{array}$ & \begin{tabular}{l|l}
$\mathrm{C}$ \\
$\mathrm{C}$ \\
\end{tabular} & \begin{tabular}{l|l}
$\mathrm{M}$ & \\
$\mathrm{G}$ & \\
\end{tabular} & -+ & & & & & \\
\hline D. ateuchus & \begin{tabular}{|l|}
$217-7-1,140-142$ \\
$217-7-3,70-72$ \\
$217-7-5,68-70$ \\
$217-7, \mathrm{CC}$ \\
\end{tabular} & \begin{tabular}{|l|}
$\mathrm{C}$ \\
$\mathrm{C}$ \\
$\mathrm{C}$ \\
$\mathrm{C}$ \\
\end{tabular} & \begin{tabular}{|l|}
$G$ \\
$G$ \\
$G$ \\
M \\
\end{tabular} & 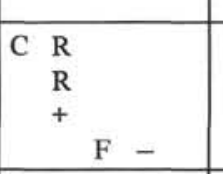 & & & & & \\
\hline T. tuberosa & \begin{tabular}{|l|}
$217-8-1,73-75$ \\
$217-8-6,148-150$ \\
$217-9-1,70-72$ \\
$217-9-3,68-70$ \\
\end{tabular} & \begin{tabular}{l|}
$\mathrm{C}$ \\
$\mathrm{C}$ \\
$\mathrm{C}$ \\
$\mathrm{C}$
\end{tabular} & \begin{tabular}{l|}
$G$ \\
$G$ \\
$G$ \\
$G$
\end{tabular} & $\begin{array}{r}F-R F \\
-R F \\
F \quad F \\
F \quad R\end{array}$ & 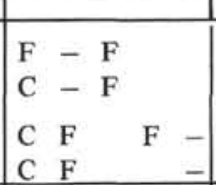 & $\left.\mid \begin{array}{lll}- & - & - \\
- & - & -\end{array}\right]$ & & & \\
\hline T. bromia & $\begin{array}{l}217-9-5,66-68 \\
217-9, \text { CC }\end{array}$ & \begin{tabular}{l|}
$\mathrm{C}$ \\
$\mathrm{C}$ \\
\end{tabular} & $\begin{array}{l}\mathrm{G} \\
\mathrm{G} \\
\end{array}$ & $\begin{array}{ll}\mathrm{R} & - \\
\mathrm{C} & -\end{array}$ & 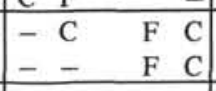 & $\begin{array}{|lllll|}C & C & C & C & F \\
C & C & F & F & C \\
\end{array}$ & $\begin{array}{l}-\cdots- \\
-\cdots\end{array}$ & & \\
\hline P. mitra & \begin{tabular}{|l}
$217-10-1,108-110$ \\
$217-10-2,68-70$ \\
$217-10-3$, top \\
\end{tabular} & \begin{tabular}{l|}
$\mathrm{C}$ \\
$\mathrm{C}$ \\
$\mathrm{C}$
\end{tabular} & \begin{tabular}{|l|}
$G$ \\
$G$ \\
$G$
\end{tabular} & & & $\begin{array}{ll}\text { C } & \text { C } \\
\text { C } & \\
\text { C } & \text { F }\end{array}$ & $\left|\begin{array}{lllll}\mathrm{C} & \mathrm{C} & \mathrm{C} & \mathrm{C} & \mathrm{F} \\
\mathrm{C} & \mathrm{F} & \mathrm{A} & \mathrm{A} & \mathrm{C} \\
\mathrm{F} & \mathrm{F} & \mathrm{C} & \mathrm{R} & \mathrm{C}\end{array}\right|$ & $\begin{array}{|lllll|}R & R & F & F & \\
& R & F & & C \\
& F & R & & F\end{array} \mid$ & $\begin{array}{l}--1 \\
-- \\
-\end{array}$ \\
\hline $\begin{array}{l}\text { P. ampla } \\
\text { T. triacantha }\end{array}$ & $\begin{array}{l}217-10-4,70-72 \\
217-10-6,68-70 \\
217-10, \text { CC }\end{array}$ & \begin{tabular}{|l|}
$\mathrm{C}$ \\
$\mathrm{C}$ \\
$\mathrm{A}$
\end{tabular} & \begin{tabular}{l|}
$G$ \\
$G$ \\
$G$
\end{tabular} & & & $\begin{array}{ll}\mathrm{C} & \\
\mathrm{C} & \mathrm{R} \\
\mathrm{C} & \mathrm{F} \\
\end{array}$ & 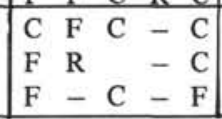 & $\begin{array}{lll}-\mathrm{C} & & \mathrm{F} \\
-\mathrm{F} & & \\
-\mathrm{R} & \mathrm{C} & \mathrm{C} \\
\end{array}$ & \begin{tabular}{|lll}
$F$ & $R$ & - \\
$F$ & $C$ & - \\
- & $A$ & $F$
\end{tabular} \\
\hline
\end{tabular}

Note: See text for explanation of symbols.

relatively resistant to corrosion, the more fragile species having already been dissolved.

\section{Site $\mathbf{2 1 5}$}

At Site 215, Radiolaria are common and well preserved in Cores 1 through 7 ( 0 to 64.5 meters) and in Core 8 (64.5 to 74 meters) Radiolaria are few to rare in abundance and moderately to poorly preserved (Table 3 ). No identifiable Radiolaria were encountered between the bottom of Core 8 (74 meters) and the base of the sediment at the basalt contact (155.5 meters) although trace amounts of siliceous debris were observed in a few samples.

The Radiolaria in Cores 1 through 8 range in age from Quaternary through upper Miocene. Quaternary assemblages in Core 1 include well-preserved specimens of Spongaster tetras tetras, Theocorythium trachelium trachelium, Ommatartus tetrathalamus, Siphocampe corbula, and
Euchitonia elegans. The base of the Quaternary lies within Core 1, between 6 and 7 meters (between Samples 215-1-4, $130-132 \mathrm{~cm}$ and $215-1-5,70-72 \mathrm{~cm})$.

Upper Tertiary radiolarian zones present in the cores include: Pterocanium prismatium Zone, Spongaster pentas Zone, Stichocorys peregrina Zone, and Ommatartus antepenultimus Zone. The following zonal boundaries can be recognized: The base of the Pterocanium prismatium Zone is between 10 and 17 meters (between Samples $215-2-1,53-55 \mathrm{~cm}$ and $215-2, \mathrm{CC})$. The base of the Spongaster pentas Zone is between 40 and 45.5 meters (between samples 215-5-3, 70-72 $\mathrm{cm}$ and 215-5, CC). The base of the Stichocorys peregrina Zone lies between 64.5 and 65.5 meters (between Samples 215-7, CC and 215-8-1, $90-92 \mathrm{~cm}$ ). The Ommatartus penultimus Zone appears to be missing at this site since the base of this zone occurs at approximately the same level as the base of the Stichocorys 
peregrina Zone. The base of the Ommatartus antepenultimus Zone occurs in the interval below Core 8, in which Radiolaria are absent or unidentifiable. The earliest identifiable radiolarian assemblage at Site 215 is at 71.5 meters (Sample 215-8-5, 78-80 $\mathrm{cm}$ ) and appears to be in the upper Ommatartus antepenultimus Zone.

The radiolarian biostratigraphy at Site 215 is in many respects similar to that obtained at the two preceding sites (213 and 214). Radiolaria are present only in the Quaternary and upper Tertiary portion of the cores; in all underlying material, Radiolaria are absent or not recognizable. The transition from unfossiliferous into highly siliceous sediments in the middle to upper Miocene portion of the cores at each of these three sites may be indicative of (1) northward crustal motion into more productive tropical latitudes during the late Cenozoic, and/or (2) regional changes in patterns of oceanic circulation and rates of primary productivity during the late Cenozoic.

\section{Sites 216, 216A}

Radiolaria in cores obtained at Sites 216 and $216 \mathrm{~A}$ (Tables 4a-c) range in age from Quaternary to Upper Cretaceous (Maastrichtian). The Quaternary and Pliocene section ( 0 to 92 meters; Cores 216-1, 216-2, and 216-3) contains moderately to poorly preserved Radiolaria. The upper Miocene to upper Eocene section (101.5 to 282 meters; Cores 216A-1 through 216-17) contains generally well preserved radiolarian assemblages. There is a transition zone near the upper/middle Eocene boundary ( 282 to 301 meters; Cores 216-18 and 216-19) within which Radiolaria are sparse and poorly to moderately preserved. Within the interval between the upper Eocene sediment and the basaltic "basement" (301 to 457 meters), Radiolaria are absent except for a few specimens of Upper Cretaceous (Maastrichtian) Radiolaria, which are present between 405.5 and 415 meters (Cores 216-30 and 216-31).

Only three cores were obtained from the Quaternary and Pliocene sediment ( 0 to 92 meters). Core 216-1 (0 to 9.5 meters) is Quaternary; Core 216-2 (44.5 to 54 meters) is in the lower Pliocene Spongaster pentas Zone; Core 216-3 ( 82.5 to 92 meters) is in the upper Miocene Stichocorys peregrina Zone.

One of the objectives of drilling at Site 216 was to obtain radiolarian-rich sediment of middle and lower Tertiary age to supplement the upper Tertiary radiolarian sequences obtained at Sites 213,214, and 215. The two holes drilled (216 and 216A) continuously cored the interval between 101.5 meters and basaltic "basement" and obtained radiolarian-rich sediment in the upper Eocene through upper Miocene part of the interval. Within these cores, the following radiolarian zonal boundaries can be recognized:

The base of the Stichocorys peregrina Zone is between 92 and 102 meters (between Samples 216-3, CC and $216 \mathrm{~A}-1-1,70-72 \mathrm{~cm})$. The base of the Ommatartus penultimus Zone is between 111 and 111.5 meters (between Samples 216A-1, CC and 216A-2-1, 66-68 cm). The base of the Ommatartus antepenultimus Zone is between 120.5 and 121 meters (between Samples 216A-2, $\mathrm{CC}$ and 216A-3-1, $43-45 \mathrm{~cm}$ ). The base of the Cannartus petterssoni Zone is between 130 and 131 meters (between Samples 216A-3, CC and 216A-4-2, 73-75 cm). The base of the Dorcadospyris alata Zone is between 147 and 149 meters (between Samples 216A-5-5, 70-72 cm and 216A-5, CC). The base of the Calocycletta costata Zone is between 158.5 and 159.5 meters (between Samples 216A-6, CC and $216-5-1,110-112 \mathrm{~cm}$ ). The base of the Calocycletta virginis Zone is between 189 and 195.5 meters (between Samples $216-8-2,30-32 \mathrm{~cm}$ and $216-8, \mathrm{CC})$. The base of the Lychnocanoma elongata Zone is between 195.5 and 196 meters (between Samples 216-8, CC and 216-9-1, 30-32 $\mathrm{cm})$. The base of the Dorcadospyris ateuchus Zone is between 234 and 234.5 meters (between Samples 216-12-1, $110-115 \mathrm{~cm}$ and 216-12-2, top). The base of the Theocyrtis tuberosa Zone is between 253.5 and 263 meters (between Samples 216-14, CC and 216-15, CC). The base of the Thyrsocyrtis bromia Zone is between 272.5 and 280 meters (between the base of Core 16 and the top of Core 17). No samples were obtained from the Podocyrtis goetheana and Podocyrtis chalara zones; consequently, there appears to be a hiatus between 272.5 and 280 meters (between the base of Core 16 and the top of Core 17). Cores 17 through 19 (280 to 301 meters) contain moderately to poorly preserved Radiolaria which are within the Podocyrtis mitra Zone.

A few Cretaceous Radiolaria, moderately well preserved, were observed in Cores 30 and 31 at Site 216. The assemblage includes the following species (see also Plate 1): Stichomitra compsa, Amphipyndax stocki, Stichomitra sp. cf $S$. cathara, Dictyomitra regina, Stichomitra (?) campi, Dictyomitra andersoni, Dictyomitra sp. cf D. multicostats, and Theocampe vanderhoofi. The age of this assemblage is probably upper Maastrichtian on the basis of previous investigations of Radiolaria of this age (Foreman, 1968; 1971).

The extent to which unconformities are present at Site 216 is difficult to ascertain because of the relatively low core recovery below a level of 177.5 meters (Core 216-6). Radiolaria suggest that there may be a hiatus in the upper Eocene section (between Cores 216-16 and 216-17), and another within the lower Miocene (between Cores 216-8 and 216-9).

\section{Site 217}

Radiolaria are present and generally well preserved in most of the samples examined from Cores 1 through 12 at Site 217 (Table 5). These cores range in age from Quaternary to middle Eocene. Below Core 12 (383 meters), Radiolaria are absent. The level at which the Radiolaria disappear coincides approximately with the level below which chert fragments are commonly present in the cores.

Because the interval within which Cores 1 through 12 were taken ( 0 to 383 meters) was not cored continuously, the radiolarian biostratigraphy at Site 217 is far from complete. the following age assignments can be made for the intervals cored:

Core 1 ( 0 to 9.5 meters) contains abundant, well-preserved Radiolaria of Quaternary age. In Core 2 (40 to 49.5 meters), which is lower Pliocene in age based on the discoaster assemblages, Radiolaria are virtually absent in the two samples examined $(217-2-1,125-217 \mathrm{~cm} ; 217-2, \mathrm{CC})$. 
Core 3 ( 70 to 79.5 meters) contains the boundary between the Stichocorys peregrina Zone at the top of the core (Sample 217-3-1, 70-72 cm) and the Ommatartus penultimus Zone in the core catcher. Core 4 (116 to 125.5 meters) is within the s,Ommartartus antepenultimus Zone. Core 5 (154 to 163.5 meters) is within the Calocycletta virginis Zone. Core 7 (230 to 239.5 meters) is within the

Dorcadospyris ateuchus Zone. Core 8 (268 to 277.5 meters) is within the upper Theocyrtis tuberosa Zone. Core 9 (306 to 315.5 meters) contains the boundary between the Theocyrtis tuberosa Zone and the Thyrosocyrtis bromia Zone. Core 10 (344 to 353.5 meters) contains three radiolarian zones of middle Eocene age: Podocyrtis mitra Zone (Samples 217-10-1, 108-110 cm and 217-10-2, 68-70 $\mathrm{cm})$; Podocyrtis ampla Zone (Sample 217-10-4, 70-72 cm); and Thyrsocyrtis triacantha Zone (Sample 217-10, CC). Core 11 (364 to 373.4 meters) was empty. Core 12 (373.5 to 383 meters) contained poorly preserved middle Eocene radiolarian fragments. Below Core 12, Radiolaria are absent.

The striking contrast between well-preserved radiolarian assemblages in Core 1 ( 0 to 9.5 meters) and Core 3 (70 to 79.5 meters) and the absence of Radiolaria in Core 2 (40 to 49.5 meters) suggested that the pelagic sediments at Site 217 might have recorded Late Cenozoic climatic cycles similar to the carbonate cycles previously identified in equatorial Pacific sediments (Arrhenius, 1952; Hays et al., 1969). Accordingly, four surface cores of Pleistocene and Pliocene age (Site 217A, Cores 1 through 4;0 to 38 meters) were obtained during a second lowering of the drill string at the same site. Radiolaria in these cores vary in abundance and preservation, ranging from common and well preserved in some intervals to virtually absent elsewhere. This variability prevented utilization of the radiolarian assemblages in these cores for paleoclimatic interpretation.

At Site 217, as at most of the other sites cored on Leg 22 , there is little indication of reworking of older microfossils into younger sediment.

\section{Site 218}

Radiolaria at Site 218 are common and well preserved only in the topmost part of Core 1 (Sample 218-1-1, 24-26 $\mathrm{cm})$. This sample contains well-preserved specimens of Theocorythium trachelium, Euchitonia elegans, Pterocanium praetextum, Amphirhopalum ypsilon, Collosphaera tuberosa, and Ommatartus tetrathalamus, indicating a Quaternary age. Within Core 1, there is a transition from pelagic, mostly biogenous, material near the top of the core to terrigenous debris at the base. This transition may coincide approximately with the Holocene/Pleistocene boundary, corresponding to a transition from predominantly turbidite deposition to predominantly pelagic deposition. At the base of Core 1 (sample 218-1, CC), a few Quaternary Radiolaria are present, but the degree of preservation has declined markedly. Below Core 1, there are scattered light-colored carbonate-rich layers within a predominantly turbidite unit. Radiolaria are absent in all samples obtained from the turbidite although a few poorly preserved radiolarian fragments are present in some samples (e.g., 218-18-1, 60-62 cm) from the carbonate layers. These fragments are insufficient in number and in preservation for age assignments.

\section{TIME RANGES OF TAXA}

The information on occurrences of Cenozoic radiolarian taxa in the eastern Indian Ocean drilling sites (Sites 213 through 217) has been synthesized in two forms: (a) a chronologically arranged list of radiolarian "events" (upper and lower limits of the ranges of taxa), and (b) a range-chart (Figure 2).

The list of events (Table 6) has been constructed in the same form as those presented in previous reports (Riedel and Sanfilippo, 1971; Sanfilippo and Riedel, 1973; Foreman, 1973). In the column with the names of taxa, T indicates the top of the range of a taxon, B the bottom, and an arrow an evolutionary transition. In the body of the table are given the pairs of core sections between which an event occurred. This is followed by the depth in meters below the sediment surface (in parentheses). The degree of reliability (for purposes of correlation) of each event at each site is indicated by the letters P, M, and G (for poor, moderate and good). A low level of realibility is in some cases the result of poor preservation of the radiolarian assemblage, and in others, of scarcity of the taxon. Ideally, the depths listed for the events should increase downward in each column, but there are some departures from this ideal which cause correlation lines to cross. In such cases, an estimation of the degree of reliability of each event in each sequence has been utilized to determine the most probable order of occurrence of events at the Leg 22 sites.

In preparing the tabulation of radiolarian events, a group of events occurring in a gap between cores can, in some cases, be arranged in stratigraphic order on the basis of results from earlier legs (Riedel and Sanfilippo, 1970, 1971; Sanfilippo and Riedel, 1973; Foreman, 1973). For example, the events at Site 216 between Samples 14, CC and 15, CC have been tabulated (see Table 6) according to the sequence of these events as determined in previous studies.

Several species which appear in the tabulations of radiolarian occurrences at each site (Tables 1-5) are not included in the sequence of radiolarian events (Table 6). Their exclusion from this tabulation was judged necessary either because of uncertainty in determining the evolutionary origin of the species, or because of sparse and intermittent occurrences of the species in the cores examined.

A radiolarian range chart (Figure 2), based on the assemblages observed in the Leg 22 cores, has been prepared. Ranges of taxa are plotted against a vertical scale corresponding to depth below the sediment surface at Site 214 (Quaternary to upper Miocene) and Site 216 (upper Miocene to middle Eocene). The depth scales at the two sites have been correlated at the base of the Ommatartus antepenultimus Zone, an event which can be precisely located at both sites (Table 6). The depth scale at Site 216 has been expanded uniformly relative to that at Site 214 so that a given vertical distance represents approximately the same period of time at the two sites.

The establishment of upper and lower limits of ranges of taxa is based on their position in the tabulation of 
TABLE 6

Radiolarian Events, Leg 22 Sites

\begin{tabular}{|c|c|c|c|c|c|c|}
\hline \multirow[b]{2}{*}{ Events $^{a}$} & \multicolumn{5}{|c|}{ Location and Reliability of Event ${ }^{b}$} & \multirow[b]{2}{*}{ Radiolarian Zones } \\
\hline & 213 & 214 & 215 & 216 & 217 & \\
\hline & & & & & & \multirow{2}{*}{ Quaternary } \\
\hline $\mathrm{T} \begin{array}{l}\text { Pterocanium } \\
\text { prismatium }\end{array}$ & $\begin{array}{l}2-3 \\
2-4 \quad G \\
(13-14)\end{array}$ & $\begin{array}{l}2, \mathrm{CC} G \\
3-2 \quad G \\
(19-21)\end{array}$ & \begin{tabular}{ll|}
$1-4$ \\
$1-5$ \\
$(5-6)$
\end{tabular} & $\begin{array}{l}1, C_{G} \\
2-1 \\
(10-45)\end{array}$ & $\begin{array}{l}\text { A-3-2 G } \\
\text { A-3-3 G } \\
(22-24) \\
\end{array}$ & \\
\hline $\begin{array}{l}\text { B Theocorythium } \\
\text { trachelium }\end{array}$ & $\begin{array}{l}3-3 \\
3, \mathrm{CC} G \\
(23-28)\end{array}$ & $\begin{array}{l}3-6 \\
3, \mathrm{CC} M \\
(27-28)\end{array}$ & $\begin{array}{l}1, C_{G} \\
2-1 \\
(9-11)\end{array}$ & $\begin{array}{l}1, C_{G} \\
2-1 \\
(10-45)\end{array}$ & $\begin{array}{l}1, C C \mathrm{G} \\
3-1 \\
(10-70)\end{array}$ & \multirow{2}{*}{ Pterocanium prismatium } \\
\hline $\begin{array}{l}\text { B Amphirhopalum } \\
\text { ypsilon }\end{array}$ & $\begin{array}{l}3-3 \quad \mathrm{M} \\
3, \mathrm{CC} \\
(23-28)\end{array}$ & $\begin{array}{l}4-2 \quad M \\
4-3 \quad M \\
(31-32)\end{array}$ & $\begin{array}{l}2, \mathrm{CC} G \\
3-1 \\
(17-18)\end{array}$ & $\begin{array}{l}1, C C_{G} \\
2-1 \\
(10-45)\end{array}$ & $\begin{array}{l}1, \mathrm{CC} G \\
3-1 \\
(10-70)\end{array}$ & \\
\hline $\begin{array}{l}\mathrm{T} \text { Stichocorys } \\
\text { peregrina }\end{array}$ & $\begin{array}{l}3, \mathrm{CC} \mathrm{G} \\
4-2 \\
(23-31)\end{array}$ & $\begin{array}{l}5-1 \quad M \\
5-3 \\
(39-42)\end{array}$ & $\begin{array}{l}2-1 \quad G \\
2, C C \\
(11-17)\end{array}$ & $\begin{array}{l}1, \mathrm{CC} G \\
2-1 \\
(10-45)\end{array}$ & $\begin{array}{l}1, \mathrm{CC} G \\
3-1 \\
(10-70)\end{array}$ & \\
\hline $\begin{array}{l}\mathrm{T} \text { Artostrobium } \\
\text { doliolum }\end{array}$ & $\begin{array}{l}4, \mathrm{CC} G \\
5, \mathrm{CC} \\
(38-47)\end{array}$ & $\begin{array}{l}6-2 \quad G \\
6-4 \quad \text { G } \\
(50-53)\end{array}$ & $\begin{array}{l}3, \mathrm{CC} G \\
4-1 \\
(26-27)\end{array}$ & $\begin{array}{l}1, C_{G} \\
2-1 \\
(10-45)\end{array}$ & $\begin{array}{l}1, \mathrm{CC} G \\
3-1 \\
(10-70)\end{array}$ & \multirow{4}{*}{ Spongaster pentas } \\
\hline $\begin{array}{l}\text { Spongaster pentas } \\
\rightarrow \text { S. tetras }\end{array}$ & $\begin{array}{l}4, C C \mathrm{G} \\
5, \mathrm{CC} \\
(38-47)\end{array}$ & $\begin{array}{l}6-2 \quad G \\
6-4 \quad G \\
(50-53)\end{array}$ & $\begin{array}{l}3, \mathrm{CC} G \\
4-1 \\
(26-27)\end{array}$ & $\begin{array}{l}1, \mathrm{CC} M \\
2, \mathrm{CC} \\
(10-54)\end{array}$ & $\begin{array}{l}1, \mathrm{CC} G \\
3-1 \\
(10-70)\end{array}$ & \\
\hline $\begin{array}{l}\text { Ommatartus penultimus } \\
\rightarrow O \text {. tetrathalamus }\end{array}$ & $\begin{array}{l}6-2 \quad G \\
6-4 \quad G 9-52) \\
(49-5\end{array}$ & $\begin{array}{l}7, \mathrm{CC}_{\mathrm{G}} \\
8-2 \\
(67-69)\end{array}$ & $\begin{array}{l}4-3 \\
4-4 \\
(30-32)\end{array}$ & $\begin{array}{l}2, \mathrm{CC} G \\
3, \mathrm{CC} \\
(54-92)\end{array}$ & $\begin{array}{l}1, \mathrm{CC} G \\
3-1 \\
(10-70)\end{array}$ & \\
\hline $\begin{array}{l}\text { Spongaster klingi } \\
\rightarrow S \text {. pentas }\end{array}$ & $\begin{array}{l}6-5 \quad G \\
6-6 \quad G \\
(53-55)\end{array}$ & $\begin{array}{l}8, C_{G} \\
9-1 \\
(76-77)\end{array}$ & $\begin{array}{l}4-3 \quad G \\
4-4 \quad G \\
(30-32)\end{array}$ & $\begin{array}{l}2, \mathrm{CC} P \\
3, \mathrm{CC} \\
(54-92)\end{array}$ & $\begin{array}{l}1, C_{G} \\
3-1 \\
(10-70)\end{array}$ & \\
\hline $\begin{array}{l}\text { B Pterocanium } \\
\text { prismatium }\end{array}$ & $\begin{array}{l}7-4, \mathrm{G} \\
7, \mathrm{CC} \\
(62-66)\end{array}$ & $\begin{array}{l}9-6 \\
9, \mathrm{CC} \text { G } \\
(84-85)\end{array}$ & $\begin{array}{l}5-3 \\
5, \mathrm{CC} G \\
(40-45)\end{array}$ & $\begin{array}{l}2, \mathrm{CC}_{\mathrm{P}} \\
3, \mathrm{CC} \\
(54-92)\end{array}$ & $\begin{array}{l}1, \mathrm{CC} G \\
3-1 \text { G } \\
(10-70)\end{array}$ & \multirow{5}{*}{ Stichocorys peregrina } \\
\hline $\begin{array}{l}\text { T Phormostichoartus } \\
\text { corona }\end{array}$ & $\begin{array}{l}6, \mathrm{CC} M \\
7-2 \\
(56-58)\end{array}$ & $\begin{array}{l}10-4 \\
10, \mathrm{CC}^{\mathrm{M}} \\
(91-95)\end{array}$ & $\begin{array}{l}5, C C_{G} \\
6-1 \\
(45-46)\end{array}$ & $\begin{array}{l}2, \mathrm{CC} P \\
3, \mathrm{CC} \\
(54-92)\end{array}$ & $\begin{array}{l}1, C C \text { G } \\
3-1 \\
(10-70)\end{array}$ & \\
\hline $\begin{array}{l}\mathrm{T} \text { Solenosphaera } \\
\text { omnitubus }\end{array}$ & $\begin{array}{l}6-6 \\
6, C C \\
(55-56)\end{array}$ & $\begin{array}{l}10, \mathrm{CC}_{\mathrm{M}} \\
11-3 \\
(95-99)\end{array}$ & $\begin{array}{l}5, \mathrm{CC}_{\mathrm{G}} \\
6-1 \\
(45-46)\end{array}$ & $\begin{array}{l}2, \mathrm{CC} P \\
3, \mathrm{CC} \\
(54-92)\end{array}$ & $\begin{array}{l}3-1 \\
3, \mathrm{CC} \\
(70-79)\end{array}$ & \\
\hline $\begin{array}{l}\text { T Acrobotrys } \\
\text { tritubus }\end{array}$ & $\begin{array}{l}8-2 \quad M \\
8-3 \quad M \\
(68-70)\end{array}$ & $\begin{array}{l}11-4 \mathrm{CC}^{\mathrm{M}} \\
11, \mathrm{C}^{-105)}\end{array}$ & $\begin{array}{l}6-1 \quad M \\
6-3 \quad M \\
(46-49)\end{array}$ & & & \\
\hline $\begin{array}{l}\text { B Solenosphaera } \\
\text { omnitubus }\end{array}$ & $\begin{array}{l}8-6 \\
8-6 \quad G \\
(73-74)\end{array}$ & $\begin{array}{l}12, \mathrm{CC}_{\mathrm{G}} \\
13-3 \\
(114-118)\end{array}$ & $\begin{array}{l}7, \mathrm{CC}_{\mathrm{M}} \\
8-1 \\
(64-65)\end{array}$ & $\begin{array}{l}\text { below } \mathrm{P} \\
3, \mathrm{CC} \\
(92)\end{array}$ & $\begin{array}{l}3, \mathrm{CC} P \\
4, \mathrm{CC} \\
(79-125)\end{array}$ & \\
\hline $\begin{array}{l}\text { Stichocorys delmontensis } \\
\rightarrow \text { S. peregrina }\end{array}$ & $\begin{array}{l}8-6 \\
8, \mathrm{CC} \text { G } \\
(74-75)\end{array}$ & $\begin{array}{l}13-3 \quad G \\
13-5 \quad G \\
(118-121)\end{array}$ & $\begin{array}{l}7, \mathrm{CC} G \\
8-1 \\
(64-65)\end{array}$ & $\begin{array}{l}3, C C \text { G } \\
\text { A-1-1 } \\
(92-120)\end{array}$ & $\begin{array}{l}3-1 \quad \mathrm{G} \\
3, \mathrm{CC} \\
(70-79)\end{array}$ & \multirow[t]{5}{*}{ MPDPDPDPDP } \\
\hline $\begin{array}{l}\text { B Spongaster } \\
\text { Klingi }\end{array}$ & $\begin{array}{l}8-6 \\
8, C C \quad G \\
(74-75)\end{array}$ & $\begin{array}{l}13-5 \quad G \\
13-6 \quad \text { G } \\
(121-122)\end{array}$ & $\begin{array}{l}7, \mathrm{CC}_{\mathrm{M}} \\
8-1 \\
(64-65)\end{array}$ & & & \\
\hline $\begin{array}{l}\text { B Acrobotrys } \\
\text { tritubus }\end{array}$ & $\begin{array}{l}8-6 \\
8, \mathrm{CC} \\
(74-75)\end{array}$ & $\begin{array}{l}14-5 \\
14, \mathrm{CC}^{\mathrm{M}} \\
(131-133)\end{array}$ & $\begin{array}{l}7, \mathrm{CC}_{\mathrm{P}} \\
8-1 \\
(64-65)\end{array}$ & & & \\
\hline $\begin{array}{l}\mathrm{T} \text { Ommatartus } \\
\text { hughesi }\end{array}$ & $\begin{array}{l}8-6 \\
8, \mathrm{CC} \\
(74-75)\end{array}$ & $\begin{array}{l}14, C_{G} \\
15-2 \\
(133-135)\end{array}$ & $\begin{array}{l}7, \mathrm{CC}_{\mathrm{G}} \\
8-1 \\
(64-65)\end{array}$ & $\begin{array}{l}A-1-3 \quad M \\
A-1-5 \\
(105-108)\end{array}$ & $\begin{array}{l}3, \mathrm{CC} G \\
4, \mathrm{CC} \\
(79-125)\end{array}$ & \\
\hline $\begin{array}{l}\text { Ommatartus antepenultimus } \\
\rightarrow O \text {. penultimus }\end{array}$ & $\begin{array}{l}8, C_{G} \\
9-1 \\
(75-77)\end{array}$ & $\begin{array}{l}14, \mathrm{CC}_{\mathrm{G}} \\
15-2 \\
(133-135)\end{array}$ & $\begin{array}{l}7, \mathrm{CC}_{\mathrm{G}} \\
8-1 \\
(64-65)\end{array}$ & $\begin{array}{l}A-1, C_{G} \\
A-2-1 \\
(111-112)\end{array}$ & $\begin{array}{l}3, C C \text { G } \\
4, C C \\
(79-125)\end{array}$ & \\
\hline
\end{tabular}


TABLE 6 - Continued

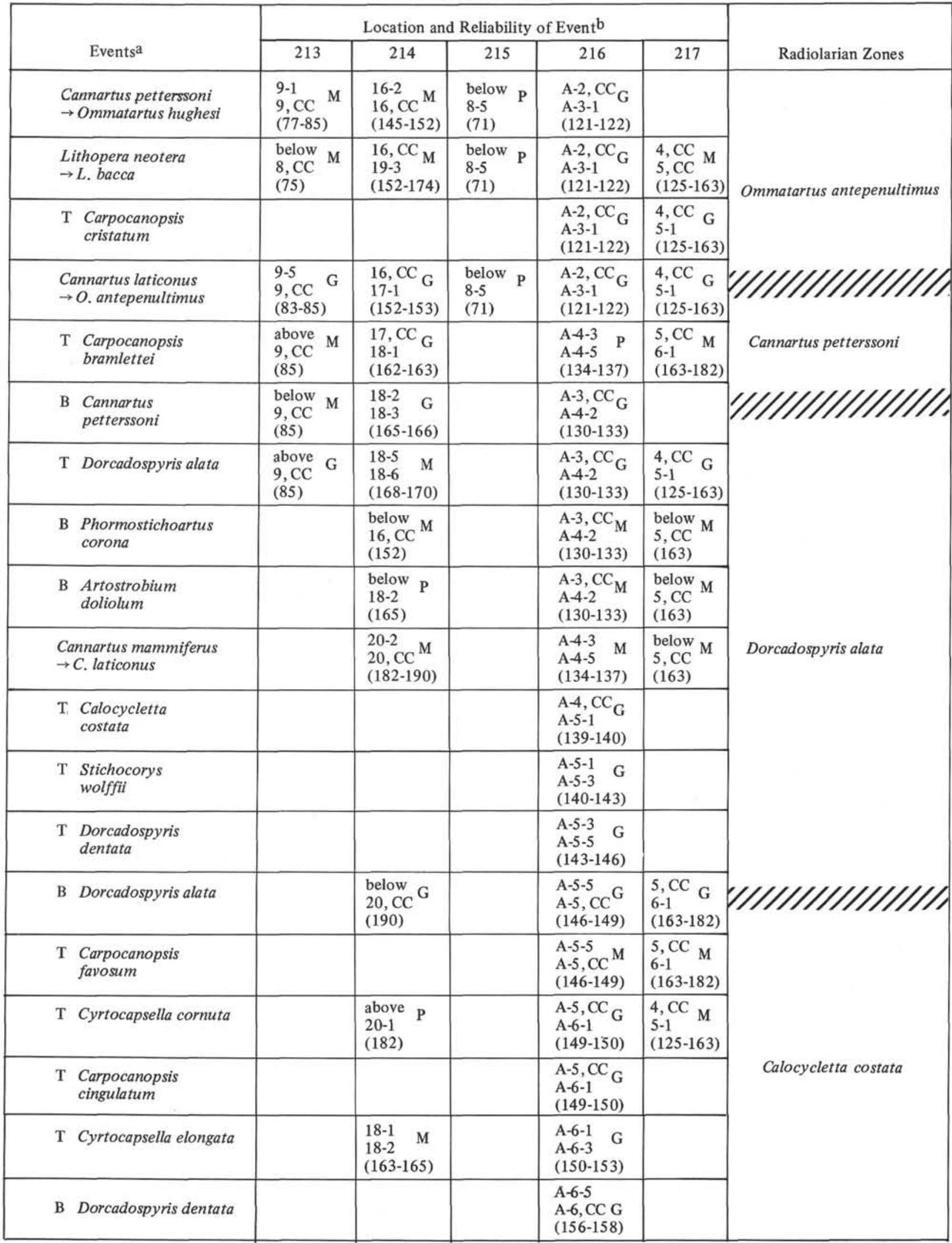


TABLE 6 - Continued

\begin{tabular}{|c|c|c|c|c|c|c|c|}
\hline & \multirow[b]{2}{*}{ Events $^{\mathrm{a}}$} & \multicolumn{5}{|c|}{ Location and Reliability of Event ${ }^{b}$} & \multirow[b]{2}{*}{ Radiolarian Zones } \\
\hline & & 213 & 214 & 215 & 216 & 217 & \\
\hline B & $\begin{array}{l}\text { Carpocanopsis } \\
\text { cristatum }\end{array}$ & & & & $\begin{array}{l}A-6, C_{G} \\
5-1 \\
(158-160)\end{array}$ & $\begin{array}{l}6-1 \\
6, C C \quad G \\
(182-192) \\
\end{array}$ & \multirow[t]{10}{*}{ Calocycletta costata } \\
\hline B & $\begin{array}{l}\text { Calocycletta } \\
\text { costata }\end{array}$ & & & & $\begin{array}{l}\mathrm{A}-6, \mathrm{CC}_{\mathrm{G}} \\
5-1 \\
(158-160)\end{array}$ & & \\
\hline $\mathrm{T}$ & $\begin{array}{l}\text { Dorcadospyris } \\
\text { simplex }\end{array}$ & & & & $\begin{array}{l}A-6, C_{G} \\
5-1 \\
(158-160)\end{array}$ & $\begin{array}{l}5, C_{G} \\
6-1 \\
(163-182)\end{array}$ & \\
\hline B & $\begin{array}{l}\text { Stichocorys } \\
\text { wolffii }\end{array}$ & & & & \multicolumn{2}{|l|}{$\begin{array}{lr}5-1 & \text { G } \\
5-4 \\
(160-164)\end{array}$} & \\
\hline $\mathrm{T}$ & $\begin{array}{l}\text { Cannartus } \\
\text { prismaticus }\end{array}$ & & & & $\begin{array}{lr}5-3 & M \\
5-4 & \\
(163-164)\end{array}$ & $\begin{array}{l}5, \mathrm{CC}_{\mathrm{G}} \\
6-1 \\
(163-182)\end{array}$ & \\
\hline B & $\begin{array}{l}\text { Stichocorys } \\
\text { delmontensis }\end{array}$ & & & & $\begin{array}{lr}5-4 & \text { G } \\
5-5 & (164-165)\end{array}$ & $\begin{array}{l}5, C_{G} G \\
6-1 \\
(163-182)\end{array}$ & \\
\hline $\mathrm{T}$ & $\begin{array}{l}\text { Cyrtocapsella } \\
\text { japonica }\end{array}$ & & & & $\begin{array}{l}5-6 \quad M \\
5, C C \quad M \\
(166-167)\end{array}$ & & \\
\hline B & $\begin{array}{l}\text { Cyrtocapsella } \\
\text { elongata }\end{array}$ & & & & $\begin{array}{l}5, \mathrm{CC} \quad \mathrm{M} \\
6-1 \quad \\
(167-169)\end{array}$ & & \\
\hline $\mathbf{T}$ & $\begin{array}{l}\text { Cyrtocapsella } \\
\text { tetrapera }\end{array}$ & & & & $\begin{array}{l}5, C C \quad G \\
6-1 \quad \text { G } \\
(167-169)\end{array}$ & & \\
\hline $\mathrm{T}$ & $\begin{array}{l}\text { Theocorys } \\
\text { spongoconum }\end{array}$ & & & & $\begin{array}{l}6-1 \\
6-2 \quad G \\
(169-170)\end{array}$ & $\begin{array}{l}6-1 \quad \mathrm{G} \\
6, \mathrm{CC} \\
(182-192)\end{array}$ & \\
\hline $\mathrm{T}$ & $\begin{array}{l}\text { Lychnocanoma } \\
\text { elongata }\end{array}$ & & & & $\begin{array}{l}6-2 \quad G \\
6-3 \quad G \\
(170-172)\end{array}$ & & \multirow{9}{*}{ Calocycletta virginis } \\
\hline $\mathbf{T}$ & $\begin{array}{l}\text { Dorcadospyris } \\
\text { ateuchus }\end{array}$ & & & & $\begin{array}{l}6-2 \\
6-3 \quad G \\
(170-172)\end{array}$ & $\begin{array}{l}5, C_{G} C^{-1} \\
(163-182)\end{array}$ & \\
\hline B & $\begin{array}{l}\text { Cyrtocapsella } \\
\text { japonica }\end{array}$ & & & & $\begin{array}{l}6-6 \quad \mathrm{G} \\
6, \mathrm{CC} \\
(176-178)\end{array}$ & & \\
\hline B & $\begin{array}{l}\text { Carpocanopsis } \\
\text { cingulatum }\end{array}$ & & & & $\begin{array}{l}6, C C \quad M \\
7-1 \quad M \\
(178-179)\end{array}$ & & \\
\hline B & $\begin{array}{l}\text { Carpocanopsis } \\
\text { bramlettei }\end{array}$ & & & & $\begin{array}{l}6, \mathrm{CC} \quad \mathrm{G} \\
7-1 \quad \\
(178-186)\end{array}$ & $\begin{array}{l}6-1 \quad M \\
6, C C \\
(182-192)\end{array}$ & \\
\hline B & $\begin{array}{l}\text { Carpocanopsis } \\
\text { favosum }\end{array}$ & & & & $\begin{array}{l}7-2 \quad \mathrm{G} \\
7, \mathrm{CC} \\
(186-187)\end{array}$ & \begin{tabular}{|l|}
$6-1 \quad M$ \\
$6, C C \quad$ \\
$(192-231)$ \\
\end{tabular} & \\
\hline B & $\begin{array}{l}\text { Calocycletta } \\
\text { robusta }\end{array}$ & & & & $\begin{array}{l}7-2 \quad \mathrm{G} \\
7, \mathrm{CC} \\
(186-187)\end{array}$ & $\begin{array}{l}6, \mathrm{CC} \\
7-1 \\
(192-231)\end{array}$ & \\
\hline B & $\begin{array}{l}\text { Cyrtocapsella } \\
\text { tetrapera }\end{array}$ & & & & $\begin{array}{l}7, \mathrm{CC} \quad \mathrm{G} \\
8-1 \quad 187-193) \\
(187\end{array}$ & & \\
\hline B & $\begin{array}{l}\text { Cyrtocapsella } \\
\text { cornuta }\end{array}$ & & & & $\begin{array}{l}8-1 \quad G \\
8-2 \quad G \\
(193-194)\end{array}$ & $\begin{array}{l}6, C_{G} \\
7-1 \\
(192-231)\end{array}$ & \\
\hline
\end{tabular}


TABLE 6 - Continued

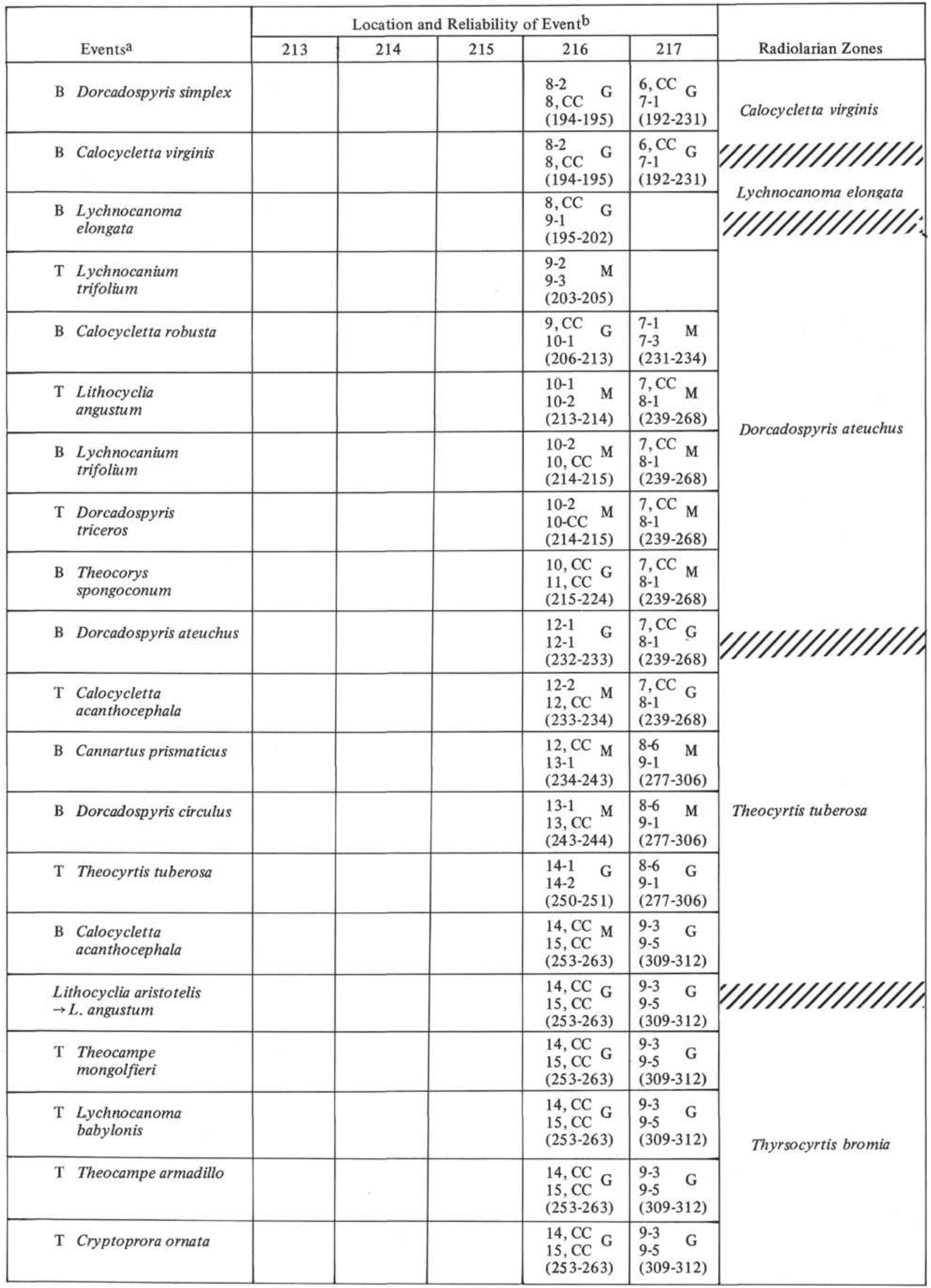


TABLE 6 - Continued

\begin{tabular}{|c|c|c|c|c|c|c|}
\hline \multirow[b]{2}{*}{ Events ${ }^{a}$} & \multicolumn{5}{|c|}{ Location and Reliability of Event ${ }^{b}$} & \multirow[b]{2}{*}{ Radiolarian Zones } \\
\hline & 213 & 214 & 215 & 216 & 217 & \\
\hline T Lophocyrtis jacchia & & & & $\begin{array}{l}14, \mathrm{CC} G \\
15, \mathrm{CC} \\
(253-263)\end{array}$ & $\begin{array}{l}9-3 \quad \text { G } \\
9-5 \quad \text { (309-312) } \\
\end{array}$ & \multirow{19}{*}{$\begin{array}{l}\text { P. goetheana Zone } \\
\text { and } \\
P \text {. chalara Zone } \\
\text { not represented }\end{array}$} \\
\hline T Calocyclas turris & & & & $\begin{array}{l}15, \mathrm{CC}_{\mathrm{G}} \\
16-1 \\
(263-269)\end{array}$ & & \\
\hline B Theocyrtis tuberosa & & & & $\begin{array}{l}15, \mathrm{CC}_{\mathrm{G}} \\
16-1 \\
(263-269)\end{array}$ & $\begin{array}{l}9-5 \\
9, \mathrm{CC} \quad \mathrm{G} \\
(312-315)\end{array}$ & \\
\hline B Artophormis gracilis & & & & $\begin{array}{l}15, \mathrm{CC}_{\mathrm{G}} \\
16-1 \\
(263-269)\end{array}$ & $\begin{array}{l}\text { below } \mathrm{G} \\
9-3 \\
(309)\end{array}$ & \\
\hline $\mathrm{T}$ Thyrsocyrtis bromia & & & & $\begin{array}{l}16-1 \quad G \\
16-2 \quad G \\
(269-270)\end{array}$ & $\begin{array}{l}9, C_{P} \\
10-1 \\
(315-344) \\
\end{array}$ & \\
\hline T Thyrsocyrtis rhizodon & & & & $\begin{array}{l}16-1 \quad G \\
16-2 \quad G \\
(269-270)\end{array}$ & $\begin{array}{l}9, \mathrm{CC}_{\mathrm{M}} \\
10-1 \mathrm{M} \\
(315-344) \\
\end{array}$ & \\
\hline T Calocyclas hispida & & & & $\begin{array}{l}16-1 \\
16-2 \\
(269-270)\end{array}$ & $\begin{array}{l}9, \mathrm{CC} \\
10-1 \\
(315-344)\end{array}$ & \\
\hline $\begin{array}{l}\mathrm{T} \text { Thyrsocyrtis } \\
\text { tetracantha }\end{array}$ & 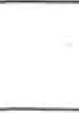 & & & $\begin{array}{l}16-1 \quad G \\
16-2 \quad G \\
(269-270)\end{array}$ & & \\
\hline $\begin{array}{l}\text { T Eusyringium } \\
\text { fistuligerum }\end{array}$ & & & & $\begin{array}{l}16-2 \quad G \\
16-3 \quad G \\
(270-271)\end{array}$ & $\begin{array}{l}9, \mathrm{CC} M \\
10-1 \quad \\
(315-344) \\
\end{array}$ & \\
\hline $\begin{array}{l}\text { Thyrsocyrtis triacantha } \\
\rightarrow T \text {. tetracantha }\end{array}$ & & & & $\begin{array}{l}16, C_{G} \\
17-1 \\
(272-280)\end{array}$ & $\begin{array}{l}9, \mathrm{CC} \text { M } \\
10-1 \text {. } \\
(315-344) \\
\end{array}$ & \\
\hline B Lophocyrtis jacchia & & & & $\begin{array}{l}16, \mathrm{CC}_{\mathrm{M}} \\
17-1 \mathrm{M} \\
(272-280)\end{array}$ & $\begin{array}{l}9, \mathrm{CC}_{\mathrm{M}} \\
10-1 \mathrm{M} \\
(315-344) \\
\end{array}$ & \\
\hline B Theocampe pirum & & & & $\begin{array}{ll}\text { below } & \mathrm{P} \\
16-3 & \\
(271) & \\
\end{array}$ & $\begin{array}{l}9, C_{M} \\
10-1 \quad \\
(315-344) \\
\end{array}$ & \\
\hline B Calocyclas turris & & & & $\begin{array}{l}16, \mathrm{CC}_{\mathrm{G}} \\
17-1 \\
(272-280)\end{array}$ & & \\
\hline B Thyrsocyrtis bromia & & & & $\begin{array}{l}16, C_{G} \\
17-1 \\
(272-280)\end{array}$ & $\begin{array}{l}9, \text { CC P } \\
10-1 \\
(315-344)\end{array}$ & \\
\hline $\begin{array}{l}\text { Lithocyclia ocellus } \\
\rightarrow L . \text { aristotelis }\end{array}$ & & & & $\begin{array}{l}\text { below G } \\
16, \mathrm{CC} \\
(272) \\
\end{array}$ & \begin{tabular}{|l|}
$9, C_{M}$ \\
$10-1$ \\
$(315-344)$ \\
\end{tabular} & \\
\hline $\begin{array}{l}\text { B Dorcadospyris } \\
\text { triceros }\end{array}$ & & & & $\begin{array}{l}\text { below } \\
16, \mathrm{CC} \\
(272) \\
\end{array}$ & $\begin{array}{l}9, \mathrm{CC}_{\mathrm{M}} \\
10-1 \quad \mathrm{M} \\
(315-344) \\
\end{array}$ & \\
\hline T Podocyrtis papalis & & & & $\begin{array}{l}16, \mathrm{CC}_{\mathrm{G}} \\
17-1 \\
(272-280)\end{array}$ & $\begin{array}{l}9, \mathrm{CC}_{\mathrm{G}} \\
10-1 \quad \mathrm{G} \\
(315-344) \\
\end{array}$ & \\
\hline $\mathrm{T}$ Theocotyle ficus & & & & $\begin{array}{l}16, \mathrm{CC}_{\mathrm{G}} \\
17-1 \\
(272-280) \\
\end{array}$ & $\begin{array}{l}9, \mathrm{CC}_{\mathrm{M}} \\
10-1 \mathrm{M} \\
(315-344) \\
\end{array}$ & \\
\hline $\begin{array}{l}\text { T Lithochytris } \\
\text { vespertilio }\end{array}$ & & & & & $\begin{array}{l}9, C_{G} \\
10-1 \\
(315-344)\end{array}$ & \\
\hline
\end{tabular}


TABLE 6 - Continued

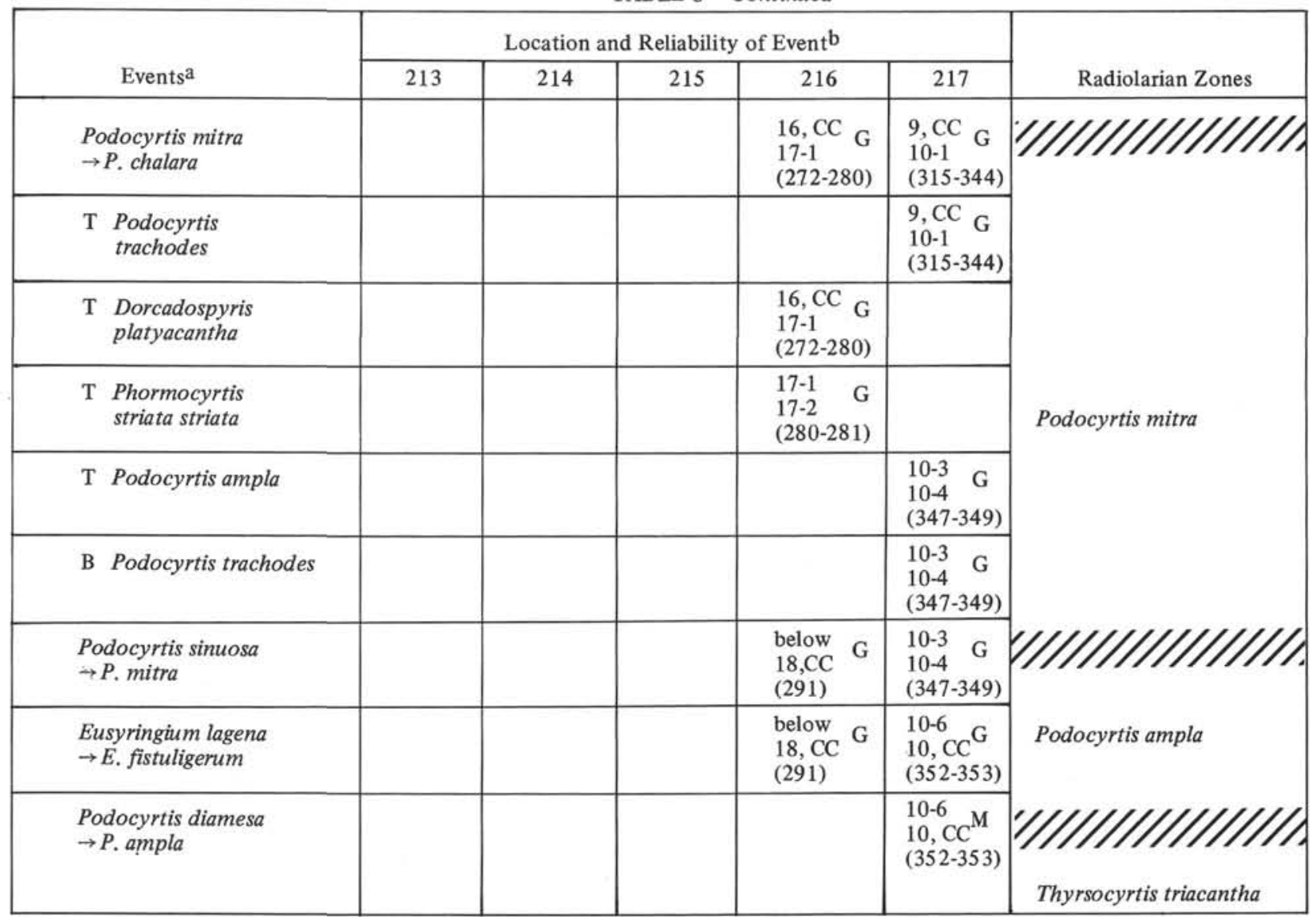

a" $T$ " indicates top and " $\mathrm{B}$ " bottom of the range of a taxon; arrow $(\rightarrow)$ indicates an evolutionary transition.

bGiven are the pair of Core (Sections) between which an event occurred; the degree of reliability of each event at each site (P, M, and $\mathrm{G}$ for poor, moderate, and good); and, in parentheses, the depth in meters below the sediment surface.

radiolarian events. Thus, some of these limits do not correspond precisely with the depth scale for the two sites indicated when information judged to be more reliable is available from another Leg 22 site. Dashed upper and lower terminations of the range lines show the amount of uncertainty in placing the limits. This uncertainty is, in some cases, due to gaps in core recovery, and in other cases, is a result of low abundance or poor preservation of the taxon. The abbreviations " $\mathrm{m}$ ", "e", and "m-e" indicate whether limits are morphotypic, evolutionary, or morphotypic-evolutionary, following the taxonomic criteria defined by Riedel and Sanfilippo (1970) and modified by Sanfilippo and Riedel (1973). Diagonal hachures are used to indicate the degree of uncertainty in placement of radiolarian zonal boundaries.

The range chart (Figure 2) is a simplification of the information presented in the list of radiolarian events (Table 6) and the lists of occurrences of species in samples examined (Tables 1-5); the reader is referred to these tables for the data used in constructing the chart.

\section{EVOLUTIONARY LINEAGES}

Previous studies of DSDP material have enabled investigators to propose several evolutionary lineages of Cenozoic radiolaria, with each lineage including from two to as many as a dozen different taxa. These lineages are discussed by Riedel and Sanfilippo (1970; 1971), Moore (1971; 1972), Sanfilippo and Riedel (1973), and Foreman (1973).

Several of the forms identified in the Leg 22 cores appear to be stratigraphically useful, and it may be possible to propose evolutionary lineages incorporating these forms after more detailed taxonomic studies are completed. These species are so indicated in the remarks included in the "Systematics Section (Cenozoic Forms)".

For the purposes of this report, the only new phylogenetic information is the morphotypic-evolutionary appearance of Calocycletta acanthocephala (Plate 6, Figure 3) from Theocyrtis tuberosa s.s. during the earliest Oligocene. It may be that this lineage continues as: Calocycletta acanthocephala $\rightarrow$ Calocycletta parva $\rightarrow$ Calocycletta robusta $\rightarrow$ Calocycletta virginis. The latter part of this lineage is that previously proposed by Moore (1972). This lineage cannot be established on the basis of the Leg 22 material, however, because of the absence of Calocycletta parva in the samples examined.

\section{DISCUSSION OF RESULTS}

\section{Preservation of Radiolarian Assemblages}

The drilling sites on the Nicobar Abyssal Fan (Site 211), Wharton Basin (Site 212), and Bengal Fan (Site 218) 
contain sparse and poorly preserved radiolarian assemblages, whereas, the sites on, and near, the Ninetyeast Ridge (Sites 213-217) contain well-preserved Radiolaria through a substantial part of the cored intervals. Dilution by terrigenous components is probably the reason for absence of Radiolaria at Sites 211 and 218. At Site 212, the absence of silica may be a consequence of this site being located in relatively unproductive latitudes.

There are three noteworthy exceptions to the presence of well-preserved radiolarian assemblages at the sites on, and near, the Ninetyeast Ridge (Sites 213-217); these exceptions should be considered in view of their tectonic and paleoclimatic implications.

1) Radiolaria are entirely absent below approximately 11 m.y. at Sites 213 and 215, and below 16 m.y. at Site 214 (see Figure 1). This is probably a consequence of the northward motion of the Indo-Australian plate during the late Cenozoic (McKenzie and Sclater, 1971) and suggests that Sites 213,214 , and 215 , migrated northward into relatively productive latitudes during the middle Miocene. The similarity of the radiolarian biostratigraphy at Sites 213 and 215 supports the interpretation that the Ninetyeast Ridge ceased to be a major transform fault during the early Cenozoic and the plates on either side become "locked" and moved northward as a single plate since the early Cenozoic (McKenzie and Sclater, 1971).

2) Radiolaria in the middle Miocene (Cannartus petterssoni and Dorcadospyris alata zones) are moderately to poorly preserved and appear to have experienced selective dissolution. The collosphaerids and orosphaerids dominate the assemblages, particularly within the $D$. alata Zone, and diagnostic species are relatively rare and poorly preserved. If this effect is indeed due to selective dissolution, it may be indicative of an influx of silica-poor bottom water into the region during the middle Miocene.

3) Quaternary and Pliocene Radiolaria are common and well-preserved at the southern sites on, and near, the Ninetyeast Ridge (Sites 213-215) but are relatively rare and poorly preserved at the equatorial site $(216)$ and the $08^{\circ} \mathrm{N}$ site (217). This variation in silica abundance is consistent with hydrographic data (Wyrtki, 1971) suggesting that the zone of highest primary productivity in the Indian Ocean is substantially to the south of the geographic equator.

\section{Reworking}

Previous studies of microfossil assemblages in piston and gravity cores from low latitudes (Riedel and Funnell, 1964; Riedel, 1971b; Funnell,1971) indicated that the reworking of older species into younger material may be commonplace. This effect in shallow cores severely limited the development of a detailed radiolarian biostratigraphy until the availability of DSDP material enabled workers to ascertain the true stratigraphic ranges of the taxa observed. Subsequent studies have shown that reworking is relatively rare in the older drilled sequences compared to the younger surface cores, suggesting that large-scale reworking may have become a significant ocean-bottom process only recently. The Leg 22 core data are consistent with this interpretation. The radiolarian assemblages consist of cooccurring species, with no evidence of reworking, at all sites except the Nicobar Fan site (211), where most of the radiolaria assemblage is probably reworked. The nannofossil assemblages in the Wharton Basin (Site 212) and on the Bengal Fan (Site 218) suggest that substantial redeposition has occurred at these locations. Otherwise, there is very little indication of reworking in the Leg 22 material.

\section{Unconformities}

Establishment of the presence of unconformities in drilled sequences is hindered by less-than-complete core recovery and by the fact that even in sequences where core recovery is supposedly 100 percent, a substantial proportion of biostratigraphic boundaries occur between cores (Moore, 1972), suggesting that some material was not recovered. Consequently, it is difficult to evaluate whether apparent unconformities (such as the missing Podocyrtis goetheana and $P$. chalara zones at Sites 216 and 217) are indeed indicative of erosion or nondeposition or whether they may be artifacts resulting from the coring process. At present, it appears that two principal types of unconformities can clearly be established in the Leg 22 cores, and that they may have major geological implications:

1) The bulk of the sediment in the Wharton Basin (Site 212) was apparently eroded from surrounding areas and deposited episodically during relatively brief intervals. The information supporting this interpretation is presented in more detail in the discussion of the lithology and biostratigraphy at Site 212 .

2) There is a striking unconformity between the lower Eocene and middle Miocene sediments at Sites 213 and 215 (Figure 1). This information, together with the presence of Eocene outcrops in the central Indian Ocean (Funnell, 1971), suggests that a major erosional episode may have occurred in the Indian Ocean during the middle Tertiary. This event evidently affected the basins on either side of the Ninetyeast Ridge (Sites 213 and 215) but not the ridge itself (Sites 214, 216, 217).

\section{Diagenesis}

The radiolarian biostratigraphy at the three sites $(214$, $216,217)$ on the crest of the Ninetyeast Ridge yields strong evidence in support of a biological origin of chert. Chert was encountered only at the two northern sites on the ridge (Sites 216 and 217), and at each of these sites, it is present in sediments of middle Eocene age and older. Radiolaria are present in the uppermost chert-bearing layers and in the overlying sediment. At Site 214, by contrast, siliceous microfossils are present only in sediments of middle Miocene age and younger (Figure 1). The data suggest that the absence of chert at Site 214 is due to the absence of siliceous microfossils of middle Eocene age at that location. This, in turn, may be explained by the fact that Site 214 was in relatively high latitudes during the Eocene and moved northward into more productive tropical latitudes only during the late Miocene (McKenzie and Sclater, 1971). Sites 216 and 217 , however, were apparently well within the productive zone by middle Eocene time, and, hence, there was a sufficient supply of siliceous material available for chert formation. 
The cherts at Sites 216 and 217 suggest that chert formation may be only partially a post-depositional process. The cherts at these two sites, as well as those encountered at other sites previously drilled by DSDP, are primarily of middle Eocene age or older. Yet, the cherts were encountered at different depths: At Site 216, the cherts were found below a depth of 280 meters, whereas, they appeared at 375 meters at Site 217 . If the formation of chert were exclusively post-depositional, one would expect the chert horizons to occur at approximately the same depth below the sea floor, corresponding to equivalent pressure and temperature conditions. Consequently, the cherts would be expected to cut across time lines in response to variable sedimentation rates. However, this does not appear to be the case since a high proportion of the cherts so far encountered by DSDP are of middle Eocene age, regardless of the present depth of these layers below the sea floor. Evidently, certain oceanographic conditions were present during the middle Eocene which were favorable to chert formation in sediments deposited during that time. Heath and Moberly (1971) have suggested that the influx of hypersaline bottom water could lead to changes in $\mathrm{pH}$ or dissolved silica of sufficient magnitude to produce silicification of surface sediments. There is strong evidence that the abyssal circulation in the Pacific did indeed experience a marked intensification at some time between the early Eocene and early Oligocene (Johnson et al., 1972; Hollister et al., in press). This, in turn, may have occurred as a consequence of the separation of Australia from Antarctica, establishing the circumpolar surface circulation and allowing Antarctic Bottom Water to penetrate eastward south of Australia and enter the Pacific Ocean. It may be that this or other tectonic events caused a marked increase in the influx of bottom water into the Indian Ocean as well.

\section{Comparison with Equatorial Pacific Assemblages}

In general, the radiolarian assemblages encountered in the eastern Indian Ocean on Leg 22 are similar to those described in previous DSDP reports based on drilling in the equatorial Pacific, the Caribbean, and the Gulf of Mexico. There are some exceptions in the relative abundance of key species; for example, Theocyrtis annosa is relatively rare in the Indian Ocean Oligocene sections. Also, there are differences in the reported stratigraphic ranges of several diagnostic species. At present it is impossible to ascertain whether these differences are real, or are merely artifacts introduced by reworking or by variability in abundance and preservation. Any substantial differences between the Leg 22 ranges and those reported previously are indicated in the remarks for each species in the Systematics Section.

\section{SYSTEMATIC SECTION (Cenozoic Forms)}

The classification of Radiolaria is based on the recent revisions proposed by Riedel $(1967 ; 1971$ a). The systematics follow closely the work of Riedel and Sanfilippo (1970; 1971; in press), Sanfilippo and Riedel (1973), and Foreman (1973) which contain more extensive synonomies than are presented here.

This section includes only those Cenozoic radiolarian taxa which were encountered on DSDP Leg 22. Systematics for the few Maastrichtian species encountered at Site 216 have been presented by Foreman (1968).
Subclass RADIOLARIA Müller 1858

Superorder POLYCYSTINA Ehrenberg 1838, emend. Riedel 1967

Order SPUMELLARIA Ehrenberg 1876

Family COLLOSPHAERIDAE Müller 1858

Genus COLLOSPHAERA Müller 1855

Collosphaera tuberosa Haeckel

(Plate 9, Figure 1)

Collosphaera tuberosa Haeckel 1887, p. 97; Nigrini, 1971, p. 445 , pl. 34.1 , fig. 1 .

Remarks: This form was found to first appear in the middle to late Pleistocene in equatorial Pacific cores (Nigrini, 1971) and was utilized, along with several other species, to define a four-fold Quaternary zonation. The Leg 22 Quaternary cores contain rare specimens of Collosphaera tuberosa but not in sufficient quantity to reliably determine its first appearance.

Genus POLYSOLENIA Ehrenberg 1872, emend. Nigrini 1967

Polysolenia spinosa (Haeckel)

(Plate 10, Figure 1)

Collosphaera spinosa Haeckel 1862, p. 536, pl. 34, figs. 12, 13.

Polysolenia spinosa (Haeckel), Nigrini, 1967, p. 14, pl. 1, fig. 1.

Remarks: This species, along with others of the genus Polysolenia described by Nigrini (1967), is present in rare amounts in the Quaternary and Pliocene Leg 22 cores. The first appearance of $P$. spinosa in the late Tertiary may prove to be a useful datum plane, but no attempt was made to establish such a datum plane in the Leg 22 material.

\section{Genus SOLENOSPHAERA Haeckel 1887}

Solenosphaera omnitubus Riedel and Sanfilippo

Solenosphaera omnitubus, Riedel and Sanfilippo, 1971, p. 1586, pl. 4 , figs. 1,2 .

Remarks: The stratigraphic range of Solenosphaera omnitubus in the Leg 22 cores was determined reasonably well at Sites 213, 214 , and 215 (see Table 6). In these cores, this species appears to be restricted entirely to the Stichocorys peregrina Zone. This is a significantly shorter range than that reported by Riedel and Sanfilippo (1971) in the initial description of this species. This discrepancy may be real or it may be reflecting problems with the abundance, preservation, or reworking of this species in some of the cores.

Family ACTINOMMIDAE Haeckel 1862, emend. Riedel 1967

Subfamily ARTISCINAE Haeckel 1881, emend. Riedel 1967

Genus CANNARTUS Haeckel 1881, emend. Riedel 1971a

Cannartus laticonus Riedel

(Plate 7, Figure 2)

Cannartus laticonus Riedel, 1959, p. 291, pl. 1, fig. 5; Riedel and Sanfilippo, 1971, pl. 1C, figs. 13-14.

\section{Cannartus mammiferus (Haeckel)}

Cannartidium mammiferum Haeckel, 1887 , p. 375 , pl. 39 , fig. 16 Cannartus mammiferus (Haeckel), Riedel, 1959, p. 291, pl. 1, fig. 4.

Remarks: The first evolutionary appearance of Cannartus mammiferus from $C$. violina is believed to occur near the top of the Calocycletta costata Zone (Riedel and Sanfilippo, 1971), but this datum was not identified in the Leg 22 cores because of low abundances (or poor preservation) of Cannartus spp. within this stratigraphic interval (see Table 4A).

\section{Cannartus (?) petterssoni Riedel and Sanfilippo} (Plate 7, Figures 6, 7)

Cannartus (?) petterssoni Riedel and Sanfilippo, 1970, p. 520, pl. 14 , fig. $3 ; 1971$, pl. 1C, figs. 19-20.

Remarks: Cannartus petterssoni is remarkably well preserved in Leg 22 cores from the $C$. petterssoni Zone (Plate 7, Figures 6-7), This species and $C$. laticonus apparently are the ones most resistant 
to corrosion in the assemblage since they are the only forms present at some sites (Table 2).

\section{Cannartus prismaticus (Haeckel)}

Pipettella prismatica Haeckel, 1887, p. 305; Riedel, 1959, p. 287 Cannartus prismaticus (Haeckel), Riedel and Sanfilippo, 1970, p. 520 , pl. 15 , fig. $1 ; 1971$, p. 1588 , pl. 2C, figs. 11-13.

Remarks: Previous studies of the artiscins (Riedel and Sanfilippo, 1970; 1971) indicate that Cannartus prismaticus evolved from Lithocyclia angustum. In the Leg 22 cores, this evolutionary transition was observed over a long stratigraphic interval, and an evolutionary datum was impossible to establish on the basis of the relative abundance of the two morphotypes. Consequently, the last occurrence of the morphotype $L$. angustum and the first appearance of the morphotype $C$. prismaticus are indicated as separate radiolarian "events" (Table 6), and no attempt was made to precisely define the levels at which the evolutionary transition occurred.

\section{Cannartus tubarius (Haeckel)}

(Plate 7, Figure 1)

Pipettaria tubaria Haeckel, 1887, p. 339; Riedel, 1959, p. 289, pl. 1, fig. 2.

Cannartus tubarius (Haeckel), Riedel and Sanfilippo, 1970, p. 520, pl. 15 , fig. 2 ; Kling, 1971 , pl. 3 , fig. 3 .

Remarks: The form designated Cannartus tubarius occurs only intermittently within the Calocycletta virginis Zone and the $C$. costata Zone (Table $4 \mathrm{~B}$ ) and in varying proportions relative to its ancestral and descendant morphotypes. As a result, it was impossible to precisely establish either the upper or the lower evolutionary limits of this species in the Leg 22 cores.

\section{Cannartus violina Haeckel}

Cannartus violina Haeckel, 1887 , p. 358 ; Riedel, 1959, p. 290, pl. 1, fig. 3; Moore, 1971, pl. 12, fig. 4 .

Remarks: As was the case with its predecessor, Cannartus tubarius, the datum planes defining the evolutionary limits of Cannartus violina could not be determined in the Leg 22 cores.

Genus OMMATARTUS Haeckel 1881, emend. Riedel 1971a

\section{Ommatartus antepenultimus Riedel and Sanfilippo} (Plate 7, Figures 3, 4)

Ommatartus antepenultimus Riedel and Sanfilippo, 1970, p. 521, pl. 14; 1971, pl. 1C, figs. 11-12.

\section{Ommatartus hughesi (Campbell and Clark)}

(Plate 7, Figures 9, 10)

Ommatocampe hughesi Campbell and Clark, 1944, p. 23, pl. 3, fig. 12.

Ommatartus hughesi (Campbell and Clark), Riedel and Sanfilippo, 1970 , p. $521 ; 1971$, pl. 1C, figs. 17-18.

Remarks: Location of the evolutionary transition from Cannartus petterssoni to Ommatartus hughesi was somewhat arbitrary because of the cooccurrence of several transitional morphologies (Plate 7, Figures 6-10) over a wide stratigraphic interval.

\section{Ommatartus penultimus (Riedel)} (Plate 7, Figure 5)

Panarium penultimum Riedel, 1957, p. 76, pl. 1, fig. 1; Riedel and Funnell, 1964, p. 311.

Ommatartus penultimus (Reidel), Riedel and Sanfilippo, 1970, p. $521 ; 1971$, pl. 1C, figs. 8-10.

\section{Ommatartus tetrathalamus (Haeckel)}

(Plate 9, Figures 5, 10)

Panartus tetrathalamus Haeckel, 1887 , p. 378 ; Nigrini, 1967, p. 30 , pl. 2 , figs. 4 a-d.

Ommatartus tetrathalamus (Haeckel), Riedel and Sanfilippo, 1971, p. 1588 , pl. $1 \mathrm{C}$, figs. $5-7$.
Remarks: In the evolutionary transition from Ommatartus penultimus to $O$. tetrathalamus, an intermediate form (O. avitus) has been described and illustrated by Riedel and Sanfilippo (1971, p. 1588 , pl. 4 , fig. 6 ). Such a form may be present in the Leg 22 cores, but for the purposes of this report it has not been incorporated into the species designations within the artiscin lineage.

\section{Family COCCODISCIDAE Haeckel 1862}

Genus LITHOCYCLIA Ehrenberg 1847a, sensu Riedel and Sanfilippo, 1970

Lithocyclia angustum (Riedel) (Plate 6, Figure 4)

Trigonactura angusta Riedel, 1959, p. 292, pl. 1, fig. 6 . Lithocyclia angustum (Riedel), Riedel and Sanfilippo, 1970, p. 522, pl. 13, figs. 1,$2 ; 1971$, pl. $3 \mathrm{~A}$, figs. 1,3 .

\section{Lithocyclia aristotelis (Ehrenberg) group}

(Plate 5, Figures 13, 14)

Astromma aristotelis Ehrenberg, 1847 b, p. 55 .

Lithocyclia aristotelis (Ehrenberg) group, Riedel and Sanfilippo, 1970 , p. $522 ; 1971$, pl. 3 A, figs. 4,5 .

\section{Lithocyclia crux Moore \\ (Plate 6, Figure 5)}

Lithocyclia crux Moore, 1971, p. 737, pl. 6, fig. 4.

\section{Lithocyclia ocellus Ehrenberg group}

Lithocyclia ocellus Ehrenberg, 1874, p. 240.

Lithocyclia ocellus Ehrenberg group, Riedel and Sanfilippo, 1970, p. 522, pl. 5, figs. 1, 2; Sanfilippo and Riedel, 1973, p. 523, pl. 10 , figs. 1,2 .

Remarks: The transition from Lithocyclia ocellus to $L$. aristotelis was not precisely located because the site which obtained cores from near this interval was not cored continuously.

Family SPONGODISCIDAE Haeckel 1862, emend. Riedel 1967

Genus AMPHIRHOPALUM Haeckel 1881, emend. Nigrini 1967

\section{Amphirhopalum ypsilon Haeckel}

(Plate 9, Figures 3, 4)

Amphirhopalum ypsilon Haeckel 1887, p. 522; Nigrini, 1967, p. 35, pl. 3 , figures $3 \mathrm{a}-3 \mathrm{~d}$.

Remarks: The form described and illustrated as Amphirhopalum ypsilon by Nigrini (1967) appears to have evolved during the late Pliocene from a form in which there is a prominent constriction which separates the chambers along each of the arms (Petrushevskaya and Kozlova, 1972, pl. 20, fig. 5).

\section{Genus EUCHITONIA Ehrenberg 1860 \\ Euchitonia elegans (Ehrenberg) \\ (Plate 9, Figure 11)}

Euchitonia elegans (Ehrenberg), Nigrini, 1967, p. 39, pl. 4, figs. 2a, 2b; Nigrini, 1970, pl. 2, fig. 6.

Remarks: This common form appears to have evolved during the late Tertiary, and its first appearance may eventually be a useful stratigraphic datum. At present, its taxonomy and its relation to other late Cenozoic spongodiscids are poorly understood.

\section{Euchitonia furcata Ehrenberg}

Euchitonia mülleri Haeckel, Nigrini, 1967, p. 37, pl. 4, figs. 1a, 1 b. Euchitonia furcata Ehrenberg, Nigrini, 1970, p. 169, pl. 2, fig. 5.

Remarks: This species apparently cooccurs with $E$. elegans, but its taxonomic position is poorly understood.

\section{Genus HYMENIASTRUM Haeckel 1887 \\ Hymeniastrum euclidis Haeckel \\ (Plate 9, Figures 7, 15)}

Hymeniastrum euclidis Haeckel, 1887, p. 531, fig. 13; Nigrini, 1970, p. 168 , pl. 2 , fig. 4 . 
Remarks: The late Cenozoic radiolarian genera Hymeniastrum, Euchitonia, and Dictyocoryne appear to be closely related (Ling, 1966; Ling and Anikouchine, 1967), but the cooccurrence of varied transitional morphologies (Plate 9, Figures 11-18) has made it difficult to define proper taxonomic relationships and establish evolutionary lineages.

\section{Genus SPONGASTER Ehrenberg 1860, emend.} Riedel and Sanfilippo 1971

Spongaster klingi Riedel and Sanfilippo

(Plate 7, Figures 19, 20)

Spongaster klingi Riedel and Sanfilippo, 1971, p. 1589, pl. 4, figs. 7, 8.

Remarks: Sanfilippo and Riedel (1973, p. 524) state that Spongaster klingi Riedel and Sanfilippo is probably a junior synonym of Spongastericus berminghami Campbell and Clark (1944). For the purposes of this report, however, the designation Spongaster klingi has been retained.

\section{Spongaster pentas Riedel and Sanfilippo} (Plate 8, Figure 15)

Spongaster pentas Riedel and Sanfilippo, 1970, p. 523, pl. 15, fig. 3.

\section{Spongaster tetras Ehrenberg}

(Plate 9, Figure 6)

Spongaster tetras Ehrenberg, 1860, p. 833; Nigrini, 1967, p. 41, pl. 5 , figs. $1 \mathrm{a}-\mathrm{b}, 2$.

Remarks: Nigrini $(1967,1970)$ describes and illustrates two subspecies of Spongaster tetras; she identifies one ( $S$. tetras tetras) as representative of low latitudes, and the other ( $S$. tetras irregularis) as representative of mid-latitudes. Both of these forms were observed in the Leg 22 samples, but no attempt was made to subdivide the species for purposes of tabulating its occurrences in the cores.

\section{Order NASSELLARIA Ehrenberg 1876}

Suborder SPYRIDA Ehrenberg 1847b, emend. Petrushevskaya 1971b Family ACANTHODESMIIDAE Haeckel 1862, emend. Riedel 1967

Genus DENDROSPYRIS Haeckel 1881, emend. Goll 1968

Dendrospyris turriturcica dasyotus Sanfilippo and Riedel

Dendrospyris turrituricica dasyotus Sanfilippo and Riedel, 1973, p. 527 , pl. 16 , fig. 3 ; pl. 32 , fig. 3 .

\section{Genus DORCADOSPYRIS Haeckel 1881, emend. Goll 1969}

\section{Dorcadospyris alata (Riedel)}

Brachiospyris alata Riedel, 1959, p. 293, pl. 1, figs. 5, 11, 12. Dorcadospyris alata (Riedel), Riedel and Sanfilippo, 1970, pl. 14, fig. 5; 1971, pl. 2D, fig. 1; Moore, 1971, pl. 11, figs. 3-4.

\section{Dorcadospyris ateuchus (Ehrenberg) (Plate 6, Figure 17)}

Ceratospyris ateuchus Ehrenberg, 1874, p. 218

Cantharospyris ateuchus (Ehrenberg), Riedel, 1959, p. 294.

Dorcadospyris ateuchus (Ehrenberg), Riedel and Sanfilippo, 1970, pl. 15 , fig. $4 ; 1971$, p. 1590 , pl. 2D, fig. 6, pl. 3A, figs. 9-10.

\section{Dorcadospyris circulus (Haeckel) (Plate 6, Figure 16)}

Gamospyris circulus Haeckel, 1887, p. 1042.

Dorcadospyris circulus (Haeckel), Moore, 1971, p. 739, pl. 8, figs. 3, 4,5 .

Remarks: Dorcadospyris circulus occurs in moderate abundance within the Oligocene sections cored on Leg 22 (Tables 4B, 5). Its position in the evolutionary lineage of the genus Dorcadospyris is difficult to establish. At Site 216 , it appears that $D$. circulus may evolve into D. riedeli. Dorcadospyris papilio (S.S.), which is commonly present in equatorial Pacific cores of this age, was not observed in any of the Oligocene cores obtained on Leg 22. The likelihood that many specimens of this genus may be incomplete compounds the problem of determining the correct phylogenetic relationships.

$$
\begin{gathered}
\text { Dorcadospyris confluens (Ehrenberg) } \\
\text { (Plate 4, Figure 4) }
\end{gathered}
$$

Petalospyris confluens Ehrenberg, 1874, p. 246; 1876, pl. 22, fig. 5. Dorcadospyris confluens (Ehrenberg), Goll, 1969, p. 337; Sanfilippo and Riedel, 1973, p. 528, pl. 17, figs. 6-10; pl. 33, fig. 1.

\section{Dorcadospyris dentata Haeckel} (Plate 8, Figure 10)

Dorcadospyris dentata Haeckel 1887, p. 1037; Riedel, 1957, p. 79, pl. 1, fig. 3.

Dorcadospyris forcipata (Haeckel), Moore, 1971, p. 740, pl. 10, figs. $1,2$.

Remarks: This species has been identified at numerous coring and drilling sites in the Pacific (Riedel, 1957; Riedel and Sanfilippo, 1971; Moore, 1971) and in the Caribbean (Riedel and Sanfilippo, 1970) where lower Miocene sediments were obtained. Dorcadospyris forcipata, however, was observed only very rarely in the Leg 22 cores. The only species of Dorcadospyris commonly observed in the lower Miocene sections were $D$. simplex and D. dentata.

\section{Dorcadospyris platyacantha (Ehrenberg)}

Petalospyris platyacantha Ehrenberg, 1874, p. 247; 1876, pl. 22, fig. 8.

Dorcadospyris platyacantha (Ehrenberg), Sanfilippo and Riedel, 1973 , p. 528 , pl. 17 , figs. $11-15$; pl. 33 , fig. 2 .

Remarks: Numerous spyrids of the genera Dorcadospyris and Giraffospyris were observed in the middle Eocene section obtained at Site 212 (Plate 3, Figures 1-7). Dorcadospyris sp. cf D. platyacantha was among the most common forms observed.

\section{Dorcadospyris riedeli Moore}

Dorcadospyris riedeli Moore, 1971, p. 739, pl. 9, figs. 1, 2, 3 .

Remarks: Dorcadospyris riedeli is rare to common in the Oligocene section obtained at Site 216 (Table 4B). Its stratigraphic range is evidently somewhat longer than that reported by Moore (1971); it apparently extends upward into the Lychnocanoma elongata (=Lychnocanüum bipes) Zone.

\section{Dorcadospyris simplex (Riedel)}

Brachiospyris simplex Riedel, 1959, p. 293, pl. 1, fig. 10.

Dorcadospyris simplex (Riedel); Riedel and Sanfilippo, 1970, pl. 15, fig. 6.

Remarks: Dorcadospyris simplex occurs through the entire Calocycletta virginis Zone at Site 216. The forms described by Moore (1971) as $D$. forcipata and $D$. praeforcipata were not observed in the Leg 22 cores.

\section{Dorcadospyris spinosa Moore (Plate 6, Figure 18)}

Dorcadospyris spinosa Moore, 1971, p. 739, pl. 7, figs. 1, 2.

Remarks: This form was observed in a sample from the Lychnocanoma elongata Zone at Site 216 as well as in a sample from the Theocyrtis tuberosa Zone. Consequently, the range of this species may be longer than the range reported by Moore (1971).

\section{Dorcadospyris triceros (Ehrenberg)}

Ceratospyris triceros Ehrenberg, 1874, p. 220.

Tristylospyris triceros (Ehrenberg); Haeckel, 1887, p. 1033; Riedel, 1959 , p. 292, pl. 1, figs. 7,8 .

Dorcadospyris triceros (Ehrenberg); Moore, 1971, p. 739, pl. 6, figs. $1,2,3$.

Genus GIRAFFOSPYRIS Haeckel 1881, emend. Goll 1969

Giraffospyris cyrillium Sanfilippo and Riedel (Plate 3, Figures 1, 2) 
Giraffospyris cyrillium Sanfilippo and Riedel, 1973, p. 528, pl. 18, figs. $1-3$; pl. 33 , fig. 3 .

\section{Giraffospyris didiceros (Ehrenberg)} (Plate 3, Figure 7)

Ceratospyris didiceros Ehrenberg, 1874, p. $218 ; 1876$, pl. 21 , fig. 6 . Giraffospyris didiceros (Ehrenberg), Goll, 1969, p. 332, pl. 60, figs. 5-7, 9

\section{Giraffospyris lata Goll}

Giraffospyris lata Goll, 1969 , p. 334, pl. 58, figs. 22, 24-26; Sanfillipo and Riedel, 1973, p. 529, pl. 18.

figs. $4-7$; pl. 33 , fig. 4 .

\section{Family THEOPERIDAE Haeckel 1881, emend. Riedel 1967}

Genus ARTOPHORMIS Haeckel 1881, sensu Riedel and Sanfilippo 1970

Artophormis barbadensis (Ehrenberg) (Plate 5, Figure 6)

Calocyclas barbadensis Ehrenberg, 1874, p. 217

Artophormis barbadensis (Ehrenberg) Haeckel, 1887, p. 1459; Riedel and Sanfilippo, 1970 , p. 532, pl. 13, fig. 5; Moore, 1971, pl. 5 , fig. 9 .

\section{Artophormis gracilis Riedel}

(Plate 6, Figure 1)

Artophormis gracilis Riedel, 1959, p. 300, pl. 2, figs. 12, 13; Riedel and Sanfilippo, 1970 , p. 532 , pl. 13, figs. 6, 7 .

Remarks: Artophormis gracilis evolved from A. barbadensis during the latest Eocene. A. gracilis is common and well preserved in the Oligocene cores obtained on Leg $22 ; A$. barbadensis, however, was only rarely observed in the underlying Eocene sections.

Genus CALOCYCLAS Ehrenberg 1847b, emend. Foreman 1973

\section{Calocyclashispida (Ehrenberg)}

(Plate 4, Figure 1)

Anthocyrtis hispida Ehrenberg, 1874, p. 216

Cycladophora hispida (Ehrenberg); Riedel and Sanfilippo, 1970, p. 529 , pl. 10, fig. 9.

Calocyclas hispida (Ehrenberg); Foreman, 1973, p. 434, pl. 1, figs. $12-15$

\section{Calocyclas turris Ehrenberg}

(Plate 5, Figure 2)

Calocyclas turris Ehrenberg, 1874, p. 218; Riedel, 1957, p. 89, pl. 3, fig. 8.

Cycladophora turris (Ehrenberg) Riedel and Sanfilippo, 1970, p. 529 , pl. 13 , figs. 3,4 .

Calocyclas turris Ehrenberg; Foreman, 1973, p. 434.

\section{Genus CALOCYCLOMA Haeckel 1887 \\ Calocycloma ampulla (Ehrenberg) \\ (Plate 5, Figure 8)}

Eucyrtidium ampulla Ehrenberg, 1874, p. 225.

Calocycloma (?) ampulla (Ehrenberg); Riedel and Sanfilippo, 1970, p. 524 , pl. 6 , fig. 1 ; Foreman, 1973 , p. 434 , pl. 1, figs. 1-5.

\section{Genus CYCLAMPTERIUM Haeckel 1887}

Remarks: The following four species of the genus Cyclamp terium were observed in rare amounts and intermittently through the Oligocene and Miocene sections cored on Leg 22. It was not possible to identify the levels at which evolutionary transitions from one species to another occurred, due to low abundances and incomplete preservation of these relatively large forms. Consequently, these transitions are not included in the tabulation of the radiolarian "events" observed on Leg 22 (Table 6).
Cyclampterium (?) brachythorax Sanfilippo and Riedel

Cyclampterium (?) brachythorax Sanfilippo and Riedel, 1970, p. 457, pl. 2, figs. 15-16; Riedel and Sanfilippo, 1971, pl. 1E, fig. 7.

Cyclampterium (?) leptetrum Sanfilippo and Riedel

Cyclampterium (?) leptetrum Sanfilippo and Riedel, 1970, p. 456, pl. 2, figs. 11, 12; Riedel and Sanfilippo, 1971, pl. 2D, figs. 9-12.

\section{Cyclampterium (?) pegetrum Sanfilippo and Riedel}

Cyclampterium (?) pegetrum Sanfilippo and Riedel, 1970, p. 456, pl. 2, figs. 8-10; Riedel and Sanfilippo, 1971, pl.2D, figs..13-14; pl. $3 \mathrm{~B}$, figs. 1-2.

Cyclampterium (?) tany thorax Sanfilippo and Riedel

Cyclampterium (?) tanythorax Sanfilippo and Riedel, 1970, p. 457, pl. 2, figs. 13, 14; Riedel and Sanfilippo, 1971, pl. 1E, figs. 8-10; pl. $2 \mathrm{D}$, figs. $7-8$.

\section{Genus CYRTOCAPSELLA Haeckel 1887, emend.} Sanfilippo and Riedel 1970

Cyrtocapsella cornuta Haeckel

Cyrtocapsa (Cyrtocapsella) cornuta Haeckel 1887, p. 1513, pl. 78, fig. 9.

Cyrtocapsella cornuta Haeckel, Sanfilippo and Riedel, 1970, p. 453, pl. 1, figs. 19, 20; Sanfilippo et al., in press, pl. 5, figs. 1, 2 .

Remarks: The stratigraphic range of Cyrtocapsella cornuta was precisely determined at Site 216 ; it extends from just above the base of the Calocycletta virginis Zone to just below the top of the $C$. costata Zone (Table 4A). This is a more restricted range than that reported by Riedel and Sanfilippo (1971) and Moore (1971) for equatorial Pacific sites.

\section{Cyrtocapsella elongata (Nakaseko)}

Theocapsa elongata Nakaseko, 1963, p. 185, pl. 3, figs. 4, 5 . Cyrtocapsella elongata (Nakaseko), Sanfilippo and Riedel, 1970, p. 452 , pl. 1, figs. 11,12 .

Remarks: Cyrtocapsella elongata may have evolved from $C$. japonica during the early Miocene or stratigraphically within the upper third of the Calocycletta virginis Zone. For the purposes of this report, however, the morphotypes of these two forms are utilized for defining their stratigraphic ranges because their proper taxonomic relationship is uncertain.

\section{Cyrtocapsella japonica (Nakaseko)}

(Plate 7, Figures 12, 13)

Eusyringium japonicum Nakaseko, 1963, p. 193, pl. 4, figs. 1-3. Cyrtocapsella japonica (Nakaseko), Sanfilippo and Riedel, 1970, p. 452 , pl. 1, figs. 13-15; Sanfilippo et al., in press, pl. 5, fig. 3.

Remarks: Cyrtocapsella japonica was observed only within a narrow interval near the middle of the Calocycletta virginis Zone. This form may have evolved from earlier species of Cyrtocapsella (perhaps $C$. tetrapera); for this report, however, the first appearance of $C$. japonica is defined morphotypically.

\section{Cyrtocapsella tetrapera Haeckel (Plate 7, Figure 11)}

Cyrtocapsa (Cyrtocapsella) tetrapera Haeckel, 1887, p. 1512. Cyrtocapsella tetrapera Haeckel; Sanfilippo and Riedel, 1970, p. 453, pl. 1, figs. 16-18; Sanfilippo et al., in press, pl. 5, figs. 4-6. Remarks: In the Leg 22 cores, Cyrtocapsella tetrapera has a much more restricted range than that reported previously for this species in equatorial Pacific cores (Riedel and Sanfilippo, 1971; Moore, 1971). At Site 216, which was cored continuously through the Oligocene-Miocene, $C$. tetrapera is restricted to the Calocycletta virginis Zone. Its first and last appearances appear to be well controlled (Table 4B). 
Genus DICOLOCAPSA Haeckel 1881

Dicolocapsa microcephala Haeckel

(Plate 6, Figure 15)

Dicolocapsa microcephala Haeckel 1887, p. 1312, pl. 57, fig. 1 .

Genus EUSYRINGIUM Haeckel 1881

Eusyringium fistuligerum (Ehrenberg)

(Plate 5, Figure 4)

Eucyrtidium fistuligerum Ehrenberg, 1874, p. 229; 1876, p. 70, pl. 9 , fig. 3.

Eusyringium fistuligerum (Ehrenberg), Riedel, 1957, p. 94, pl. 4, fig. 8; Riedel and Sanfilippo, 1970 , p. 527 , pl. 8, figs. 8, 9; Foreman, 1973, p. 435, pl. 11, fig. 6 .

\section{Eusyringium lagena (Ehrenberg) (?)}

(Plate 5, Figure 3)

(?) Lithopera lagena Ehrenberg, 1874, p. 241.

Eusyringium lagena (Ehrenberg) (?); Riedel and Sanfilippo, 1970, p. 527 , pl. 8, figs. 5-7; Foreman, 1973, p. 435, pl. 11, figs. 4, 5 .

Remarks: The evolutionary transition from Eusyringium lagena

to E. fistuligerum occurs in the middle Eocene Podocyrtis ampla Zone, as reported previously (Sanfilippo and Riedel, 1973).

Genus LAMPTONIUM Haeckel 1887

Lamptonium fabaeforme fabaeforme (Krasheninnikov) (?) (Plate 2, Figure 9)

Cyrtocalpis fabaeformis Krasheninnikov, 1960, p. 296, pl. 3, fig. 11. Lamptonium (?) fabaeforme fabaeforme (Krasheninnikov) (?), Riedel and Sanfilippo, 1970, p. 523, pl. 5, fig. 6; Foreman, 1973 , p. 436, pl. 6, figs. 6-9.

Remarks: This species is rare to common in samples from the middle Eocene section (Cores 19-23) of Site 212. Its cooccurrence with specimens of Theocampe mongolfieri gives a precise age for the samples as within the $T$. mongolfieri Zone.

\section{Genus LITHOCHYTRIS Ehrenberg $1847 \mathrm{a}$}

\section{Lithochytris vespertilio Ehrenberg}

Lithochytris vespertilio Ehrenberg, 1874, p. 239; Riedel and Sanfilippo, 1970, p. 528, pl. 9, figs. 5, 6 .

Remarks: The upper limit of this species was not precisely identified in the Leg 22 material because the zone within which this event occurs (Sanfilippo and Riedel, 1973), the Podocyrtis chalara Zone, was missing from both sites which recovered upper Eocene sediment.

\section{Genus LITHOPERA Ehrenberg 1847a \\ Subgenus LITHOPERA Ehrenberg 1847a \\ Lithopera (Lithopera) bacca Ehrenberg}

Lithopera bacca Ehrenberg, 1872, p. 314: Nigrini, 1967, p. 54, pl. 6, fig. 2; Sanfilippo and Riedel, 1970, p. 455, pl. 1, fig. 29.

Lithopera (Lithopera) neotera Sanfilippo and Riedel

Lithopera neotera Sanfilippo and Riedel, 1970, p. 454, pl. 1, figs. 24-26, 28.

Remarks: The evolutionary transition from Lithopera neotera to $L$. bacca occurs at the base of the Ommatartus antepenultimus Zone, as determined previously by Riedel and Sanfilippo (1971).

Lithopera (Lithopera) renzae Sanfilippo and Riedel

Lithopera renzae Sanfilippo and Riedel, 1970, p. 454, pl. 1, figs. 21-23, 27.

Subgenus GLOMARIA Sanfilippo and Riedel, 1970

Lithopera (Glomaria) baueri Sanfilippo and Riedel

Lithopera baueri Sanfilippo and Riedel, 1970, p. 455, pl. 2, figs. $1-2$.
Remarks: This species occurs sparsely and intermittently in the Miocene cores obtained on Leg 22, but it is not sufficiently abundant to allow a precise determination of its stratigraphic range.

\section{Lithopera (Glomaria) thornburgi Sanfilippo and Riedel}

Lithopera thornburgi Sanfilippo and Riedel, 1970, p. 455, pl. 2, figs. 4-6.

Remarks: As with $L$. baueri, this species is not sufficiently abundant in the Leg 22 cores to allow precise determination of its stratigraphic range. This small and relatively rare species was identified at Site 216, where it is restricted to the upper Dorcadospyris ateuchus Zone. This range is somewhat shorter than that initially reported for the species (Sanfilippo and Riedel, 1970).

\section{Genus LOPHOCYRTIS Haeckel 1887 \\ Lophocyrtis (?) jacchia (Ehrenberg) (Plate 5, Figure 5)}

Thyrsocyrtis jacchia Ehrenberg, 1874, p. 261.

Lophocyrtis (?) jacchia (Ehrenberg); Riedel and Sanfilippo, 1970, p. 530 ; 1971, pl. 3C, figs. 4, 5; pl. 7, fig. 16; Moore, 1971, pl. 5, figs. 4,7 .

\section{Genus LYCHNOCANIUM Ehrenberg 1847a}

Lychnocanium trifolium Riedel and Sanfilippo

Lychnocanium trifolium Riedel and Sanfilippo, 1971, p. 1595, pl. 8 , figs. 2,3 .

Genus LYCHNOCANOMA Haeckel 1887, emend. Foreman, 1973

\section{Lychnocanoma babylonis (Clark and Campbell) group} (Plate 2, Figure 13)

Dictyophymus babylonis Clark and Campbell, 1941, p. 67, pl. 9, figs. 32,36 .

Sethochytris babylonis (Clark and Campbell) group, Riedel and Sanfilippo, 1970 , p. 528 , pl. 9, figs. 1-3.

Lychnocanoma babylonis (Clark and Campbell) group, Foreman, 1973, p. 437, pl. 2 , fig. 1.

\section{Lychnocanoma elongata (Vinassa)}

Tetrahedrina elongata Vinassa, 1900, p. 243, pl. 2, fig. 31.

Lychnocanium bipes Riedel, 1959, p. 294, pl. 2, figs. 5, 6; Riedel and Sanfilippo, 1971, pl. 2F, figs. 1-2.

Lychnocanoma elongata (Vinassa), Sanfilippo et al., in press, pl. 5, figs. 19, 20.

Remarks: This species, most commonly known as Lychnocanium bipes Riedel, has recently been renamed Lychnocanoma elongata (Vinassa) by Sanfilippo et al (in press). In the Site 216 cores, the upper limit of this species is well below the top of the Calocycletta virginis Zone (Table 4B). Hence, its stratigraphic range is approximately the same as that reported by Moore (1971) for this species but somewhat less than the range reported by Riedel and Sanfilippo (1971).

\section{Genus PHORMOCYRTIS Haeckel 1887 \\ Phormocyrtis embolum (Ehrenberg) (Plate 4, Figure 5)}

Eucyrtidium embolum Ehrenberg 1874, p. 228; 1876, pl. 10, fig. 5 . Phormocyrtis embolum (Ehrenberg), Haeckel, 1887, p. 1369; Riedel, 1957 , p. 88, pl. 3, figs. 6-7.

\section{Phormocyrtis striata striata Brandt} (Plate 2, Figures 6,7)

Phormocyrtis striata Brandt, Riedel and Sanfilippo, 1970, p. 532, pl. 10 , fig. 7 .

Phormocyrtis striata striata Brandt, Foreman, 1973, p. 438, pl. 7, figs. 5, 6.9.

\section{Genus PTEROCANIUM Ehrenberg 1847a}

Pterocanium praetextum (Ehrenberg)

(Plate 9, Figures 8,9) 
Lychnocaniumpraetextum Ehrenberg, 1872, p. 297, pl. X, fig. 2. Pterocanium praetextum (Ehrenberg), Riedel, 1957, p. 86, pl. 3, figs. 103; Moore, 1971, pl. 13, fig. 3 .

Remarks: Nigrini (1967) describes and illustrates two subspecies of Pterocanium praetextum, both of which were observed in the Leg 22 cores. No distinction between the two was made, however, in the tabulations of occurrences. An attempt was made to establish the level of first appearance of this species in the late Tertiary; this attempt was unsuccessful due to the rare and intermittent occurrences of P.praetextumin the samples examined.

\section{Pterocanium prismatium Riedel}

(Plate 8, Figure 11)

Pterocanium prismatium Riedel, 1957 , p. 87 , pl. 3, figs. 4-5; Riedel and Sanfilippo, 1971, pl. 8, fig. 1.

Remarks: In the Leg 22 cores, the disappearance of Pterocanium prismatium coincides with the Globorotalia tosaensis $\rightarrow G$. truncatulinoides transition and the disappearance of discoasters. Consequently, the use of any of these three "events" appears to remain as a suitable criteria for identifying the Pliocene/Pleistocene boundary

\section{Genus RHOPALOCANIUM Ehrenberg 1847a \\ Rhopalocanium ornatum Ehrenberg (Plate 5, Figure 18)}

Rhopalocanium ornatum Ehrenberg, 1847 b, fig. $3 ; 1854$, pl. 36, fig. $9 ; 1873$, p. 256 ; 1876 , p. 82 , pl. 17 , fig. 8 ; Foreman, 1973, p. 439 , pl. 2 , figs. $8-10$; pl. 12 , fig. 3 .

\section{Genus STICHOCORYS Haeckel 1881; Riedel and Sanfilippo, 1970 \\ Stichocorys delmontensis (Campbell and Clark) (Plate 8, Figure 13)}

Eucyrtidium (Eucyrtis) delmontense Campbell and Clark, 1944, p. 56; Riedel, 1952, pl. 1, fig. 5.

Stichocorys delmontensis (Campbell and Clark), Sanfilippo and Riedel, 1970, p. 451, pl. 1, Fig. 9; Riedel and Sanfilippo, 1971, pl. $1 \mathrm{~F}$, figs. $5-7 ;$ pl. $2 \mathrm{E}$, figs. 10,11 .

\section{Stichocorys peregrina (Riedel)}

(Plate 8, Figure 12)

Eucyrtidium elongatum peregrinum Riedel, 1953 , p. 812 , pl. 85 , fig. 2 .

Stichocorys peregrina (Riedel), Riedel and Sanfilippo, 1970, p. 530; 1971 , pl. 8 , fig. 5 .

\section{Stichocorys wolffii Haeckel}

Stichocorys wolffii Haeckel, 1887, p. 1479; Riedel, 1954, p. 173 pl. 1, fig. 4; Riedel, 1957, p. 92, pl. 4, figs. 6, 7; Riedel and Sanfilippo, 1971, pl. 2E, figs. 8, 9.

Remarks: The range of Stichocorys wolffii extends from the top of the Calocycletta virginis Zone to the lower Dorcadospyris alate Zone in the Leg 22 cores. This is a somewhat shorter range for the species than that reported by Riedel and Sanfilippo (1971) and may be a consequence of relatively poor preservation of the radiolarian assemblages from the $D$. alata and $C$. petterssoni zones (Tables 1-5).

\section{Genus THEOCORYS Haeckel 1881, emend. Riedel and} Sanfilippo 1970, Foreman 1973

\section{Theocorys spongoconum Kling}

(Plate 6, Figure 2)

Theocorys spongoconum Kling, 1971, p. 1087, pl. 5, fig. 6; Riedel and Sanfilippo, 1971 , pl. 2F, fig. 4 ; pl. 3C, fig. 3.

Remarks: In the Leg 22 cores, the range of Theocorys spongoconum was found to extend from the middle Dorcadospyris ateuchus $\mathrm{Z}$ one to the upper Calocycletta virginis Zone. Sanfilippo and Riedel (1973, Table 9) indicate the first appearance of $T$. spongoconum to be somewhat lower, within the Theocyrtis tuberosa Zone, but this estimate is judged of poor reliability because it is based on occurrences of $T$. spongoconum in trace amounts only
(Foreman, 1973). Consequently, there is still considerable uncertainty in locating the first appearance of this species, and in establishing whether or not it is part of a longer evolutionary lineage.

Genus THEOCOTYLE Riedel and Sanfilippo, 1970

Subgenus THEOCOTYLE Riedel and Sanfilippo, 1970; Foreman, 1973

Theocotyle (Theocotyle) cryptocephala cryptocephala (Ehrenberg) (Plate 2, Figure 8)

Eucyrtidium cryptocephalum Ehrenberg, 1874, p. $227 ; 1876$, p. 70 , pl. 11, fig. 11.

Theocotyle cryptocephala cryptocephala (Ehrenberg), Riedel and Sanfilippo, 1970 , p. 525, pl. 6, figs. 7, 8 .

Theocotyle (Theocotyle) cryptocephala cryptocephala (Ehrenberg), Foreman, 1973, p. 440, pl. 4, figs. 6, 7.

\section{Subgenus THEOCOTYLISSA Foreman, 1973}

Theocotyle (Theocotylissa) ficus (Ehrenberg) (Plate 4, Figure 10,11)

Eucyrtidium ficus Ehrenberg, 1874, p. 228; 1876, p. 70, pl. 11, fig. 19.

Theocotyle (?) ficus (Ehrenberg), Riedel and Sanfilippo, 1970, p. 525 , pl. 7 , figs. $3-5$.

Theocotyle (Theocotylissa) ficus (Ehrenberg), Foreman, 1973, p. 441 , pl. 4 , figs. 16-20.

\section{Genus THYRSOCYRTIS Ehrenberg 1847b,} Sensu Reidel and Sanfilippo in press

Thyrsocyrtis bromia Ehrenberg (Plate 5, Figure 7)

Thyrsocyrtis bromia Ehrenberg, 1874 , p. $260 ; 1876$, p. 84 , pl. 12, fig. 2; Riedel and Sanfilippo, 1970 , p. 526; 1971, pl. 8, fig. 6; Moore, 1971, pl. 5, figs. 1-3.

Remarks: In the Leg 22 cores, Thyrsocyrtis bromia is restricted to the lower part of the $T$. bromia Zone. This range is somewhat shorter than that reported initially by Riedel and Sanfilippo (1970), but it is in substantial agreement with their subsequent more complete tabulation of Eocene radiolarian "events" (Sanfilippo and Riedel, 1973, Table 9).

\section{Thyrsocyrtis hirsuta hirsuta (Krasheninnikov)}

Podocyrtis hirsutus Krasheninnikov, 1960, p. 300, pl. 3, fig. 16.

Thyrsocyrtis hirsuta hirsuta (Krasheninnikov), Riedel and Sanfilippo, 1970, p. 526, pl. 7, fig. 9; Foreman, 1973, p. 441, pl. 3, figs. 3-8.

\section{Thyrosocyrtis hirsuta robusta Riedel and Sanfilippo}

Thyrsocyrtis hirsuta robusta Riedel and Sanfilippo, 1970, p. 526, pl. 8 , fig. 1 ; Foreman, 1973 , p. 442 , pl. 3, fig. 17.

\section{Thyrsocyrtis rhizodon Ehrenberg} (Plate 4, Figures 6-9)

Thyrosocyrtis rhizodon Ehrenberg, 1874, p. 262; 1876, p. 94, pl. 12 , fig. 1; Riedel and Sanfilippo, 1970 , p. 525 , pl. 7, figs. 6, 7; Foreman, 1973, p. 442, pl. 3, figs. 1, 2.

\section{Thyrsocyrtis tetracantha (Ehrenberg)} (Plate 5, Figure 15)

Podocyrtis tetracantha Ehrenberg, 1874, p. 254; 1876, p. 82, pl. 13, fig. 2.

Thyrsocyrtis tetracantha (Ehrenberg), Riedel and Sanfilippo, 1970, p. 527 ; Moore, 1971 , pl. 4 , fig. 3 .

\section{Thyrsocyrtis triacantha (Ehrenberg)} (Plate 5, Figure 16)

Podocyrtis triacantha Ehrenberg, 1874, p. 254; 1876, p. 82, pl. 13, fig. 4 . 
Thyrsocyrtis tricantha (Ehrenberg), Riedel and Sanfilippo, 1970, p. 526, pl. 8, figs. 2, 3; Foreman, 1973, p. 442, pl. 12, figs. 9-11.

Remarks: The evolutionary transition from Thyrsocyrtis triacantha to $T$. tetracantha occurs above the base of the $T$. bromia Zone (Table 6). This observation is consistent with previous studies (Foreman, 1973; Sanfilippo and Riedel, 1973) and has required elimination of the $T$. tetracantha Zone from the Eocene radiolarian zonation.

\section{Family CARPOCANIIDAE Haeckel 1881, emend. Riedel 1967}

Genus CARPOCANOPSIS Riedel and Sanfilippo 1971

Carpocanopsis bramlettei Riedel and Sanfilippo

(Plate 8, Figures 4, 5)

Carpocanopsis bramlettei Riedel and Sanfilippo, 1971, p. 1597, pl. 2G, figs. 8-14; pl. 8, fig. 7 .

Remarks: Carpocanopsis bramlettei ranges from the lower Calocycletta virginis Zone to the Cannartus petterssoni Zone at the Leg 22 sites. This range appears slightly longer than that reported for this species by Riedel and Sanfilippo (1971).

\section{Carpocanopsis cingulatum Riedel and Sanfilippo} (Plate 8, Figure 7)

Carpocanopsis cingulatum Riedel and Sanfilippo, 1971, p. 1597, pl. 2G, figs. $17-21$; pl. 8, fig. 8 .

Remarks: The first appearance of Carpocanopsis cingulatum has been previously reported to occur in the Lychnocanoma elongata (= Lychnocanium bipes) Zone (Riedel and Sanfilippo, 1971). In the Leg 22 cores, the first appearance of $C$. cingulatum was substantially above the base of the Calocycletta virginis Zone.

\section{Carpocanopsis cristatum (Carnevale)?} (Plate 8, Figure 1)

?Sethocorys cristata Carnevale, 1908, p. 31, pl. 4, fig. 18.

Carpocanopsis cristatum (Carnevale)? Riedel and Sanfilippo, 1971, p. 1597 , pl. 1G, fig. 16; pl. 2G, figs. 1-7.

Remarks: The stratigraphic range of this species in the Leg 22 cores is essentially the same as that reported previously (Riedel and Sanfilippo, 1971) for western Pacific cores.

\section{Carpocanopsis favosum (Haeckel)}

(Plate 8, Figure 3)

Cycladophora favosa Haeckel, 1887, p. 1380, pl. 62, figs. 5, 6 . Carpocanopsis favosum (Haeckel), Riedel and Sanfilippo, 1971, p. 1597 , pl. 2 G, figs. 15,16 ; pl. 8, figs. 9-11.

Remarks: The stratigraphic range of this species in the Leg 22 cores is essentially the same as that reported previously (Riedel and Sanfilippo, 1971).

\section{Family PTEROCORYTHIDAE Haeckel 1881, emend. Riedel 1967, Moore 1972}

Genus ANTHOCYRTIDIUM Haeckel 1881, sensu Petrushevskaya in Petrushevskaya and Kozlova, 1972

\section{Anthocyrtidium angulare Nigrin}

(Plate 9, Figure 2)

Anthocyrtidium angulare Nigrini 1971, p. 445, pl. 34.1, figs. 3a, $3 \mathrm{~b}$.

Remarks: Anthocyrtidium angulare was utilized by Nigrini (1971) to construct a radiolarian zonation for the Quaternary. This species was observed only rarely and intermittently within the Quaternary cores from Leg 22, and no attempt was made to establish its stratigraphic range or to subdivide the Quaternary on the basis of its occurrences.

\section{Genus CALOCYCLETTA Haeckel 1887, emend. Riedel 1967, Moore 1972 \\ Calocycletta acanthocephala (Ehrenberg) \\ (Plate 6, Figure 3)}

Eucyrtidium acanthocephala (Ehrenberg), Petrushevskaya and Kozlova, 1972, p. 544, pl. 35, figs. 5-7.
Remarks: Calocycletta acanthocephala apparently originated from Theocyrtis tuberosa during the earliest Oligocene, approximately at the Eocene/Oligocene boundary. It is distinguished from $T$. tuberosa s.s. by its somewhat smaller overall size, by its smoother shell surface, and by a more regular size and spacing of the thoracic pores. It apparently coexisted with $T$. tuberosa in the earliest Oligocene, but its extinction was significantly later than that of $T$. tuberosa, occurring at the top of the T. tuberosa Zone (Table 6).

Calocycletta acanthocephala bears some similarity to one of the subsequent species of the genus Calocycletta described by Moore (1972), namely, Calocycletta parva. Consequently C. acanthocephela may eventually prove to be part of a lineage from Theocyrtis tuberosa to Calocycletta virginis. This relationship cannot be established on the basis of the Leg 22 samples because Calocycletta parva, the form which Moore (1972) suggests as the precursor of $C$. robusta, was not observed in cores from either of the sites $(216,217)$ at which upper Oligocene sediment was obtained.

\section{Calocycletta costata (Riedel)}

(Plate 8, Figure 9)

Calocyclas costata Riedel, 1959, p. 296, pl. 2 , fig. 9.

Calocycletta costata (Riedel), Riedel and Sanfilippo, 1970, p. 535, pl. 14, fig. 12; Moore, 1972, p. 147, pl. 1, fig. 8.

\section{Calocycletta robusta Moore}

Calocycletta robusta Moore, 1971, p. 743, pl. 10, figs. 5, 6; 1972, p. 48 , pl. 1 , fig. 6.

Remarks: Moore (1972) suggests that Calocycletta robusta evolved from a very rare form described as $C$. parva. Inasmuch as $C$. parva was not identified in Leg 22 material, the lower limit of the species $C$. robusta is designated by its first morphotypic appearance.

\section{Calocycletta virginis (Haeckel)}

Calocyclas virginis Haeckel, 1887 , p. 1381 , pl. 74 , fig. 4; Riedel, 1957 , p. 90 , pl. 4 , figs. $3-4$; Riedel, 1959 , p. 295 , pl. 2 , fig. 8 . Calocycletta virginis (Haeckel), Riedel and Sanfilippo, 1970, p. 535, pl. 14, fig. 10; Moore, 1972, p. 147, pl. 1, fig. 7.

Remarks: The species described by Moore (1972) as Calo. cycletta serrata may cooccur with $C$. virginis in samples from the lower $C$. virginis Zone. However, distinguishing between these two species is difficult unless the abdominal feet are completely preserved. This criterion was seldom met by the specimens obtained on Leg 22. Calocycletta caepa, which Moore (1972) proposes to be a descendatn of $C$. virginis, was not observed in any of the Leg 22 samples.

\section{Genus CRYPTOPRORA Ehrenberg \\ Cryptoprora ornata Ehrenberg (Plate 5, Figure 9)}

Cryptoprora ornata Ehrenberg, 1874 , p. $222 ; 1876$, pl. 5 , fig. 8 ; Riedel and Sanfilippo, 1971, pl. 3D, figs. 10-11; Sanfilippo and Riedel, 1973, p. 530, pl. 35, figs. 3, 4 .

\section{Genus EUCYRTIDIUM Ehrenberg 1847a \\ Eucyrtidium acuminatum (Ehrenberg) (Plate 10, Figure 15)}

Lithocampe acuminata Ehrenberg 1844, p. 84.

Eucyrtidium acuminatum (Ehrenberg), Nigrini, 1967, p. 81, pl. 8, figs. 3a, 3b; Nigrini, 1970, pl. 4, fig. 1; Bandy et al; 1971, pl. 2, fig. 5 .

Remarks: Eucyrtidium acuminatum, together with the related form $E$. hexagonatum, occurs rarely and intermittently in the Quaternary and Pliocene cores obtained on Leg 22. Nigrini (1967) indicates that $E$. acuminatum is most abundant in Recent assemblages from middle latitudes, whereas, $E$. hexagonatum is more characteristic of low latitudes. The presence of both species within the Leg 22 cores may be a reflection of fluctuating surface water temperatures and climatic conditions during the late Cenozoic. No attempt was made to determine the relative proportions of $E$. acuminatum and $E$. hexagonatum within each sample. The first appearances of these two species in the late Tertiary may prove to 
be useful stratigraphic datum planes, but these levels were not determined for the Leg 22 core material because of the uncertain taxonomic relationships of the various forms of the genus Eucyrtidium which occur in the Neogene (Sanfilippo et al., in press).

\section{Eucyrtidium calvertense Martin}

(Plate 10, Figure 9)

Eucyrtidium calvertense Martin, 1904, p. 450; Hays, 1965, pl. 3, fig. 4; Kling, 1971, pl. 1, fig. 3.

Remarks: This form (Plate 10, Figure 9) has been previously identified in late Cenozoic sediments from middle latitudes (Kling, 1971) and high latitudes (Hays, 1965) but has not been reported to be present in low latitude assemblages (Nigrini, 1967; 1968; 1971). It occurs rarely and intermittently in the Quaternary and Pliocene cores from Leg 22 sites, and its presence may be indicative of relatively cold climatic conditions.

\section{Eucyrtidium cienkowskii Haeckel group (Plate 6, Figure 7)}

Eucyrtidium cienkowskii Haeckel, 1887, p. 1493; Sanfilippo et al. in press, pl. 5, figs. 7-11.

Remarks: ,The form illustrated (Plate 6, Figure 7) is common and well preserved in the Oligocene cores obtained at Sites 216 and 217. However, the forms which are presently included in this group have a wide variety of morphologies (Sanfilippo et al., in press, pl. 5, figs. 7-11) which apparently extend over a much longer stratigraphic interval, perhaps most of the Neogene. Attempts to divide the group into species have been unsuccessful (Sanfilippo et al., in press).

\section{Eucyrtidium hexagonatum Haeckel}

(Plate 10, Figure 14)

Eucyrtidium hexagonatum Haeckel, 1887, p. 1489; Nigrini, 1967, p. 83, pl. 8, figs. 4a, 4b; Nigrini, 1970 , pl. 4 , fig. 2.

Remarks: (see remarks for Eucyrtidium acuminatum).

Genus LAMPROCYCLAS Haeckel 1881, sensu

Petrushevskaya and Kozlova, 1972

Lamprocyclas heteroporos Hays

(Plate 10, Figures 2, 3)

Lamprocyclas heteroporos Hays, 1965 , p. 179, pl. 3, fig. 1; Kling, 1971, pl. 1, fig. 1 .

Remarks: Lamprocyclas heteroporos has been reported in Quaternary sediments from high latitudes (Hays, 1965) and middle latitudes (Kling, 1971) but has not been previously reported in equatorial regions (Nigrini, 1967; 1968; 1971). This species is rare to common in the Leg 22 cores (see Plate 10, Figures 2-5). Its range extends downward from the Recent at least as far as the lower Pliocene and perhaps into the Miocene. The phylogenetic relationship between this species and others of the genus Lamprocyclas is uncertain.

\section{Lamprocyclas maritalis maritalis Haeckel} (Plate 10, Figure 11)

Lamprocyclas maritalis Haeckel, 1887, p. 1390.

Lamprocyclas maritalis maritalis Haeckel, Nigrini, 1967, p. 74, pl. 7, fig. 5 .

Lamprocyclas maritalis Haeckel polypora Nigrini (Plate 10, Figure 12)

Lamprocylcas maritalis Haeckel polypora Nigrini 1967, p. 76, pl. 7, fig. 6 .

\section{Genus PODOCYRTIS Ehrenberg 1847a \\ Subgenus PODOCYRTIS Ehrenberg, sensu Riedel and Sanfilippo, 1970 \\ Podocyrtis (Podocyrtis) ampla Ehrenberg}

Podocyrtis (?) ampla Ehrenberg, 1874, p. 248; 1876, pl. 16, fig. 7.

Podocyrtis (Podocyrtis) ampla Ehrenberg, Riedel and Sanfilippo, 1970 , p. 533 , pl. 12 , figs. 7,8 .

\section{Podocyrtis (Podocyrtis) diamesa Riedel and Sanfilippo}

Podocyrtis (Podocyrtis) diamesa Riedel and Sanfilippo, 1970, p. 53, pl. 12, fig. 4; Sanfilippo and Riedel, 1973, p. 531, pl. 20, figs. 9, 10 ; pl. 35 , figs. 10,11 .

\section{Podocyrtis (Podocyrtis) papalis Ehrenberg} (Plate 4, Figure 12)

Podocyrtis papalis Ehrenberg, 1847b, fig. 2; 1874, p. 251; Riedel and Sanfilippo, 1970 , p. 533, pl. 11, fig. 1; Sanfilippo and Riedel, 1973, p. 531 , pl. 20 , figs. 11-14; pl. 36 , figs. $2,3$.

Subgenus LAMPTERIUM Haeckel 1881, sensu Riedel and Sanfilippo, 1970

Podocyrtis (Lampterium) chalara Riedel and Sanfilippo

Podocyrtis (Lampterium) chalara Riedel and Sanfilippo, 1970, p. 535 , pl. 12 , figs. 2,3 .

\section{Podocyrtis (Lampterium) goetheana (Haeckel)}

Cycladophora goetheana Haeckel, 1887, p. 1376, pl. 65, fig. 5 .

Podocyrtis (Lampterium) goetheana (Haeckel), Riedel and Sanfilippo, 1970, p. 535; 1971, pl. 8, fig. 13.

Remarks: Neither Podocyrtis goetheana nor $P$. chalara was encountered within the Eocene sediments cored on Leg 22 (Sites $216,217)$. There is evidently a regional unconformity of late Eocene age separating latest Eocene (Thyrsocyrtis bromia Zone) sediments from middle Eocene sediments.

\section{Podocyrtis (Lampterium) mitra Ehrenberg} (Plate 4, Figure 15)

Podocyrtis mitra Ehrenberg, 1854, pl. 36, fig. B 20; 1874, p. 251.

Podocyrtis (Lampterium) mitra Ehrenberg, Riedel and Sanfilippo, 1970 , p. 534 , pl. 11 , figs. 5,6 .

\section{Podocyrtis (Lampterium) sinuosa Ehrenberg (?)} (Plate 4, Figure 18)

?Podocyrtis sinuosa Ehrenberg, 1874, p. $253 ; 1876$, pl. 15, fig. 5 . Podocyrtis (Lampterium) sinuosa Ehrenberg (?), Riedel and Sanfilippo, 1970, pl. 11, figs. 3,4 .

\section{Podocyrtis (Lampterium) trachodes Riedel and Sanfilippo (Plate 5, Figures 11, 12)}

Podocyrtis (Lampterium) trachodes Riedel and Sanfilippo, 1970, p. 535 , pl. 11, fig. 7 ; pl. 12, fig. 1 .

\section{Genus THEOCORYTHIUM Haeckel 1887 \\ Theocory thium trachelium (Ehrenberg) (Plate 10, Figures 6, 7, 8)}

Eucyrtidium trachelius Ehrenberg 1872, p. 293, pl. 7, fig. 8 .

Theocorythium trachelium (Ehrenberg), Nigrini, 1967, p. 79, pl. 8 , fig. 2 .

Remarks: Theocorythium trachelium first appeared in the late Pliocene; this event appears to be a useful biostratigraphic datum.

\section{Genus THEOCYRTIS Haeckel 1887 \\ Theocyrtis annosa (Riedel)}

Phormocyrtis annosa Riedel, 1959, p. 295 , pl. 2 , fig. 7 .

Theocyrtis annosa (Riedel), Riedel and Sanfilippo, 1970, p. 535, pl. 15 , fig. 9.

Remarks: This species is commonly observed in Oligocene sediments of the equatorial Pacific but is relatively rare in the Leg 22 cores of Oligocene age (Tables 4B, 5).

\section{Theocyrtis tuberosa Riedel}

Theocyrtis tuberosa Riedel, 1959, p. 258, pl. 2, figs. 10, 11; Moore, 1971 , p. 743 , pl. 5, figs. 5,6 .

Remarks: Theocyrtis tuberosa s.s. has a limited stratigraphic range in the Leg 22 cores. It first appears in the latest Eocene (Thyrsocyrtis bromia Zone), and its last occurrence is in the earliest 
Oligocene (lower $T$. tuberosa Zone). It apparently evolved into a form (Calocycletta acanthocephala) which has a smoother shell surface.

\section{Family ARTOSTROBIIDAE Riedel 1967, emend. Foreman 1973 \\ Genus ARTOSTROBIUM Haeckel 1887}

Artostrobium doliolum Riedel and Sanfilippo (Plate 7, Figures 14, 15)

Artostrobium doliolum Riedel and Sanfilippo, 1971, p. 1599, pl. 1 H, figs. 1-3; pl. 8, figs. 14,15 .

\section{Artostrobium miralestense (Campbell and Clark)} (Plate 10, Figure 10)

Dictyocephalus miralestensis Campbell and Clark, 1944, p. 45, pl. 6, figs. 12-14.

(?) Eucyrtidium tumidulum Bailey, 1856, p. 5, pl. 1, fig. 11; Hays, 1965 , p. 181, pl. 3, fig. 7; Kling, 1971, p. 1089, pl. 1, fig. 2.

Artostrobium miralestense (Campbell and Clark), Riedel and Sanfilippo, 1971 , p. 1599 , pl. 1H, figs. 9-17; pl. 2I, figs. 9-10; pl. 3E, fig. 12.

\section{Genus LITHOMITRA Bütschli 1881 \\ Lithomitra docilis Foreman (Plate 3, Figure 16)}

Lithomitra docilis Foreman, 1973, p. 431, pl. 8, figs. 20-22; pl. 9, figs. 3-5.

\section{Genus PHORMOSTICHOARTUS Campbell, 1951 \\ Phormostichoartus corona (Haeckel)} (Plate 7, Figure 18)

Cyrtophormis (Acanthocyrtis) corona Haeckel, 1887, p. 1462, pl. 77 , fig. 15 .

Phormostichoartus corona (Haeckel), Riedel and Sanfilippo, 1971, p. 1600 , pl. 1I, fig. 12 ; pl. 2I, fig. 17; pl. 3E, figs. 15-19.

\section{Genus SIPHOCAMPE Haeckel, 1881 \\ Siphocampe corbula (Harting)}

Lithocampe corbula Harting, 1863, p. 12, pl. 1, fig. 21.

Siphocampe corbula (Harting), Riedel and Sanfilippo, 1971, p. 1601 , pl. 1H, figs. 18-25.

Remarks: This long-ranging late Cenozoic species is common in most of the Leg 22 cores. However, it is relatively rare in the oldest cores in which it appears, and, consequently, it is difficult to reliably determine the stratigraphic level of its first appearance.

\section{Genus THEOCAMPE Haeckel 1887}

Theocampe amphora (Haeckel) group

(Plate 2, Figure 4; Plate 4, Figure 2)

Dictyocephalus amphora Haeckel, 1887, p. 1305, pl. 62, fig. 4 .

Theocampe amphora (Haeckel) group, Foreman, 1973, p. 431, pl. 8, figs. 7, 9-13; pl. 9, figs. 8, 9 .

\section{Theocampe armadillo (Ehrenberg) group}

Eucyrtidium armadillo Ehrenberg, 1874 , p. $225 ; 1876$, p. 70 , pl. 9 , fig. 10.

Theocampe armadillo (Ehrenberg) group, Riedel and Sanfilippo, 1971, p. 1601, pl. 3E, figs. 3-6.

Theocampe mongolfieri (Ehrenberg)

(Plate 2, Figures 3, 5; Plate 5, Figure 1)

Eucyrtidium mongolfieri Ehrenberg, 1874, p. 230; 1876, p. 72, pl. 10 , fig. 3 .

Theocampe mongolfieri (Ehrenberg), Burma, 1959, p. 239; Riedel and Sanfilippo, 1970, p. 536, pl. 12, fig. 9; Foreman, 1973, p. 432 , pl. 8 , fig. 1 ; pl. 9 , fig. 17.
Theocampe pirum (Ehrenberg)

(Plate 6, Figure 14)

Eucyrtidium pirum Ehrenberg, 1874, p. 232; 1876, p. 72, pl. 10, fig. 14.

Theocampe pirum (Ehrenberg), Riedel and Sanfilippo, 1971, p. 1601, pl. 3E, figs. 10, 11; Foreman, 1973, pl. 9, figs. 11, 12.

\section{Family CANNOBOTRYIDAE Haeckel 1881, emend.} Riedel 1967

Genus ACROBOTRYS Haeckel 1881, sensu

Riedel and Sanfilippo 1971

Acrobotrys tritubus Riedel

(Plate 7, Figure 16)

Acrobotrys tritubus Riedel, 1957, p. 80, pl. 1, fig. 5; Riedel and Sanfilippo, 1971, pl. 1J, figs. 19, 20.

Remarks: The range of Acrobotrys tritubus in the Leg 22 cores (Figure 2) is somewhat shorter than that reported initially (Riedel and Sanfilippo, 1971). This discrepancy is probably attributable to the small size and relatively rare abundance of this species in most assemblages.

Genus BOTRYOCYRTIS Ehrenberg 1860 , sensu Riedel and Sanfilippo 1971

Botryocyrtis scutum (Harting) (Plate 9, Figure 20)

Haliomma scutum Harting 1863, p. 11, pl. 1, fig. 18 .

Botryocyrtis scutum (Harting), Nigrini, 1967, p. 52, pl. 6, figs. 1a-1c; Nigrini, 1970, pl. 4, fig. 13 .

Remarks: The first appearance of this species in the late Tertiary may prove to be a useful biostratigraphic datum, but no attempt was made to establish such an event in the Leg 22 cores.

\section{Genus BOTRYOPYLE Haeckel, 1881}

\section{Botryopyle dictyocephalus Haeckel group} (Plate 6, Figure 6)

Botryopyle dictyocephalus Haeckel, 1887, p. 1113, pl. 96, fig. 6. Botryopyle dictyocephalus Haeckel group, Riedel and Sanfilippo, 1971 , p. 1602 , pl. 1 J, figs. $21-26$; pl. 2 J, figs. $16-18$; pl. $3 \mathrm{~F}$, figs. 9-12.

\section{Genus CENTROBOTRYS Petrushevskaya 1965}

Centrobotrys petrushevskayae Sanfilippo and Riedel

Centrobotrys petrushevskayae Sanfilippo and Riedel, 1973, p. 532, pl. 36 , figs. 12,13 .

\section{Centrobotrys thermophila Petrushevskaya}

Centrobotrys thermophila Petrushevskaya, 1965, p. 115; Nigrini, 1967 , p. 49, pl. 5, fig. 7; Riedel and Sanfilippo, 1971, pl. 1J, figs. 27-31; pl. 2J, fig. 19; pl. 3F, fig. 14.

\section{Incertae Sedis}

\section{Genus LOPHOCYRTIS Haeckel 1887 \\ Lophocyrtis biaurita (Ehrenberg) (Plate 2, Figures 1, 2)}

Eucyrtidium biauritum Ehrenberg, 1874, p. 226; 1876, p. 70, pl. 10 , figs. 7,8 .

Lophocyrtis biaurita (Ehrenberg), Haeckel, 1887, p. 1411; Cita, Nigrini and Gartner, 1970 p. 404, pl. 2, figs. I-K; Foreman, 1973 , p. 442 , pl. 8 , figs. $23-26$.

\section{Genus LOPHOPHAENA Ehrenberg $1847 \mathrm{~b}$, emend.} Petrushevskaya 1971a

\section{Lophophaena (?) capito Ehrenberg group}

? Lophophaena capitos Ehrenberg, 1874, p. 242; 1876, pl. 8, fig. 6 . Lophophaena (?) capito Ehrenberg group, Petrushevskaya and Kozlova, 1972, p. 535, pl. 33, figs. 20-23. 


\section{ACKNOWLEDGMENTS}

Financial support for this investigation was provided under N.S.F. Grant No. GA-36825. I thank W. R. Riedel, A. Sanfilippo, C. Nigrini, and H. Foreman for useful discussions and assistance in the identification of several radiolarian specimens. The difficult task of typing and proofreading the manuscript was superbly performed by Elaine Bruer.

\section{REFERENCES}

Arrhenius, G., 1952. Sediment cores from the east Pacific. Repts. Swed. Deep-Sea Exped., v. 5, pt. 1, 89 pp.

Bailey, J. W., 1856. Notice of microscopic forms found in the soundings of the Sea of Kamtschatka - with a plate. Am. J. Sci., ser. 2, v. 22, p. 1-6.

Bandy, O. L., Casey, R. E., and Wright, R. C., 1971. Late Neogene planktonic zonation, magnetic reversals, and radiometric dates, Antarctic to the Tropics. In Antarctic Oceanology I: Ant. Res. Ser. Washington (Am. Geophys. Union), v. 15, p. 1-26.

Berggren, W. A., 1972. A Cenozoic time scale-some implications for regional geology and paleobiogeography: Lethaia, v. 5, p. 195-215.

Bronnimann, P., Martini, E., Resig, J., Riedel, W. R., Sanfilippo, A., and Worseley, T., 1971. Biostratigraphic synthesis: late Oligocene and Neogene of the western tropical Pacific. In Winterer, E. L., Riedel, W. R., et al., Initial Reports of the Deep Sea Drilling Projects, Volume VII: Washington (U.S. Government Office), p. 1723-1745.

Burma, B. H., 1959. On the status of Theocampe Haeckel, and certain similar genera. Micropaleontology, v. 5, p. 325-330.

Bütschli, O., 1881. Beiträge zur kenntnis der Radiolarienskelette insbesondere der Cyrtida. Z. Wiss. Zool., v. 36, p. 485-540.

Campbell, A. S., 1951. New genera and subgenera of Radiolaria: J. Paleontology, v. 25, p. 527-530.

Campbell, A. S. and Clark, B. L., 1944. Miocene radiolarian faunas from southern California. Geol. Soc. Am. Spec. Paper 51, p. 1-76.

Carnevale, P., 1908. Radiolarie e silicoflagellati di Bergonzano (Reggio Emilia): R. Ist. Veneto Sci. Lett. Arti, Mem. 28 , no. 3, p. 146 .

Cita, M. B., Nigrini, C. and Gartner, S., 1970. Biostratigraphy. Peterson, M. N. A., Edgar, N. T., et al., In Initial Reports of the Deep Sea Drilling Project, Volume II. Washington (U.S. Government Printing Office), p. 391-411.

Clark, B. L. and Campbell, A. S., 1942. Eocene radiolarian faunas from the Mt. Diablo area, California: Geol. Soc. Am. Spec. Paper 39

Dietz, R. S. and Holden, J. C., 1970. The breakup of Pangaea: J. Gephys. Res., v. 75, p. 5939.

Ehrenberg, C. G., 1838. "Über die Bildung der Kreidefelsen und des Kreidemergels durch unsichtbare Organismen": Abh. Kal. Preuss. Akad. Wiss. Berlin Jahrg. 1838, p. 59-147.

, 1844. "Über zwei neue Lager von Gebirgsmassen aus Infusorien": K. Preuss. Akad. Wiss. Berlin, Jahre 1844 , p. 57-97.

1947. Über eine halibiolithische, von Herrn R. Schomburgk entdeckte, vorhenschend aus mikroskopischen Polycystinen gebildete, Gebirgsmasse von Barbados: Mber Preuss. Akad. Wiss. Berlin, Jahrg. 1846, p. 382-385.
$1847 \mathrm{~b}$. Über die mikroskopischen kieselschaligen Polycystinen als mächtige Gebirgsmasse von Barbados und über das Verhältnes der aus mehr als 300 neuen Arten bestehenden gang eigenthümlichen Formengruppe jener Felsmasse zu den lebenden Thieren und zur Kreidebildung. Eine neue Anregung zur Erforschung des Erdlebens: Mber. Preuss. Akad. Wiss. Berlin Jahrg. 1847, p. 40-60.

1854. Mikrogeologie: Leipzig (Voss) $374 \mathrm{pp}$

1860. Über den Tiefgrund des stillen Oceans zwischen Californien und den Sandwich-Inseln aus bis $15,600^{\prime}$ Tiefe nach Lieut. Brooke: Mber. Preuss. Akad. Wiss. Berlin, Jahrg. 1860 , p. $819-833$.

1872. Mikrogeologische Studien über das kleinste Leben der Meeres-Tiefgründe aller Zonen und dessen geologischen Einfluss: Abh. Preuss. Akad. Wiss. Berlin, Jahrg. 1872, p. 131-399.

1874. Grössere Felsproben des PolycystinenMergels von Barbados mit weiteren Erläuterungen: Mber. Preuss. Akad. Wiss. Berlin, Jahrg. 1873, p. 213-263.

1876. Forsetzung der mikrogeologischen Studien als Gesammt-Ubersicht der mikroskopischen Paläontologie gleichartig analysirter Gebirgsarten der Erde, mit specieller Rücksicht auf den Polycystinen-Mergel von Barbados: Abh. Preuss. Akad. Wiss. Berlin, Jahrg. 1875, p. 1-226.

Foreman, H. P., 1968. Upper Maestrichtian radiolaria of California: Paleontol. Assoc. London, Spec. Paper 3, P. 1-82.

1971. Cretaceous radiolaria, Leg 7, DSDP. In Winterer, E. L., Riedel W. R., et al., Initial Reports of the Deep Sea Drilling Project, Volume VII: Washington (U.S. Government Printing Office), p. 1673-1693.

1973. Radiolaria of Leg 10 with systematics and ranges for the families Amphypyndacidae, Artostrobiidae, and Theoperidae. In Worzel, J. L., Bryant, W., et al., Initial Reports of the Deep Sea Drilling Project, Volume X: Washington (U.S. Government Printing Office), p. 407-474.

Funnell, B. M., 1971. The occurrence of pre-Quaternary microfossils in the oceans. In The Micropaleontology of Oceans, Funnell, B.M. and Riedel, W. R. (Eds.): (Cambridge University Press) p. 507-534.

Goll, R. M., 1968. Classification and phylogeny of Cenozoic Trissocyclidae (Radiolaria) in the Pacific and Caribbean basins, Part I: J. Paleont., v. 42, p. 1409-1432.

1969. Classification and phylogeny of Cenozoic Trissocyclidae (Radiolaria) in the Pacific and Caribbean basins, Part II: J. Paleont., v. 43, p. 322-339.

Haeckel, E., 1862. Die Radiolarien (Rhizopoda Radiolaria): Berlin, (Reimer) 572 pp.

1881. Entwurf eines Radiolarien-Systems auf Grund von Studien der Challenger-Radiolarien: Jena. Z. Naturw., v. 15 , no. 3, p. 418-472.

1887. Report on the Radiolaria collected by H.M.S. Challenger during the years 1873-76: Rept. Voyage Challenger, Zool., v. 18, 1803 pp.

Harting, P., 1863. Bijdrage tot de Kennis M. Kroskopische Fauna en Flora van de Banda-Zee: K. Akad. v. Wetensch., Amsterdam, Verh., v. 10, p. 2-34.

Hays, J. D., 1965. Radiolaria and late Tertiary and Quaternary history of Antarctic seas: (Am. Geophys. Union). Ant. Res. ser. 5, Biol. of Ant. Seas II, Washington p. 125-184.

Hays, J. D., Saito, T., Opdyke, N. D., and Burckle, L. H., 1969. Pliocene-Pleistocene sediments of the equatorial 
Pacific: their paleomagnetic, biostratigraphic, and climatic record: Geol. Soc. Am. Bull., v. 80, p. 1481-1514.

Heath, G. R. and Moberly, R., 1971. Cherts from the western Pacific, Leg 7, Deep Sea Drilling Project. In Winterer, E. L., Riedel, W. R., et al., Initial Reports of the Deep Sea Drilling Project, Volume VII: Washington (U.S. Government Printing Office), p. 991-1007.

Hollister, C. D., Johnson, D. A., and Lonsdale, P. F., in press. Current-controlled abyssal sedimentation: Samoan Passage, equatorial west Pacific: J. Geol.

Johnson, D. A., Hollister, C. D., and Lonsdale, P. F., 1972. Carbonate sedimentation and abyssal circulation in the Samoan Passage: Geol. Soc. Am. Abstr. Prog., v. 4, p. 554.

Kling, S., 1971. Radiolaria: Leg 6 of the Deep Sea Drilling Project. In Fischer, A. G., Heezen, F. C., et al., Initial Reports of the Deep Sea Drilling Project, Volume VI: Washington (U.S. Government Printing Office), p. 1069-1117.

Krasheninnikov, V. A., 1960. Some radiolarians of the lower and middle Eocene of the western pre-Caucasus: Min. Geol. i Okhr. Nedr. SSR, Vses. Nauch.-Issled. Geol. Neft. Inst., no. 16, p. 271-301.

Ling, H., 1966. Notes on patagium in the radiolarian genera Hymeniastrum and Dictyastrum; Micropaleontology, v. 12, p. $489-492$.

Ling, H. and Anikouchine, W. A., 1967. Some spumellarian Radiolaria from the Java, Philippine, and Mariana trenches: J. Paleontol., v. 41, p. 1481-1491.

Martin, G. C., 1904. Radiolaria: Maryland Geol. Survey, Miocene, p. $447-459$.

McKenzie, D. and Sclater, J. G., 1971. The evolution of the Indian Ocean since the Late Cretaceous, Geophys. J. R. Astr. Soc., v. 25 , p. 437-528.

Moore, T. C., 1971. Radiolaria. In Tracey, J. I. Jr., Sutton, G. H., et al., Initial Reports of the Deep Sea Drilling Project, Volume VIII: Washington (U.S. Government Printing Office) p. 727-775.

1972. Mid-Tertiary evolution of the radiolarian genus Calocycletta: Micropaleontology, v. 18, p. 244-152.

Müller, J., 1855. Über die im Hafen von Messina beobachteten Polycystinen: Kgl. Preuss, Akad. Wiss. Berlin, Jahre. 1855, p. 671-674.

1858. Über die Thalassicollen, Polycystinen und Acanthometren des Mittelmeeres: Abh. Preuss. Akad. Wiss. Berlin, Jahrg. 1858, p. 1-62.

Nakaseko, K., 1963. Neogene Cyrtoidea (Radiolaria) from the Isozaki Formation in Kbaraki Prefecture, Japan; Osaka Univ., Sci. Rept., v. 12, no. 2, p. 165-198.

Nigrini, C. A., 1967. Radiolaria in pelagic sediments from the Indian and Atlantic oceans: Scripps Instit. Oceanog. Bull., v. 11, p. 1-106.

1968. Radiolaria from eastern tropical Pacific sediments: Micropaleontology, v. 14, p. 51-63.

1970. Radiolarian assemblages in the north Pacific and their application to a study of Quaternary sediments in core V20-130. In Geological Investigations of the North Pacific. Hays, J. D. (Ed): Geol. Soc. Am. Mem. 126, p. 139-183.

1971. Radiolarian zones in the Quaternary of the equatorial Pacific Ocean. In The Micropaleontology of the Oceans. Funnell, B. M. and Riedel W. R. (Eds): (Cambridge Univ. Press) p. 443-461.

Petrushevskaya, M. G., 1965. Peculiarities of the construction of the skeleton of Botryoid Radiolarians (Order
Nassellaria); Tr. Zool. Inst. (Akad. Nauk SSSR), v. 35, p. 79-118.

1971a. Radiolarii Nassellaria $v$ planktone Mirovogo Okeana: Issled. fauny morey, Leningrad. $1971 \mathrm{~b}$. On the natural system of polycystine Radiolaria (Class Sarcodina): Planktonic Conf. 2nd, Roma 1970, Proc., p. 981-992.

Petrushevskaya, M. G. and Kozlova, G. E., 1972. Radiolaria: Leg 14, Deep Sea Drilling Project. In Hayes, D. E., Pimm, A.C., et al., Initial Reports of the Deep Sea Drilling Project, Volume XIV: Washington (U.S. Government Printing Office), p. 495-648.

Riedel, W. R., 1952. Tertiary Radiolaria in western Pacific sediments: Goteborgs Kurgl, Vetenskaps VitterhetsSamhälles Handlingan, ser. B, v. 6, no. 3, p. 3-21. 1953. Mesozoic and late Tertiary Radiolaria of Rotti; J. Paleont., v. 27, p. 805-813.

1954. The age of the sediment collected at Challenger Station 225, and the distribution of Ethmodiscus rex; Deep-Sea Res. v. 1, p. 170-175. 1957. Radiolaria: a preliminary stratigraphy: Rept. Swed. Deep Sea Expd., v. 6, no. 3, p. 61-96. , 1959. Oligocene and lower Miocene Radiolaria in tropical Pacific sediments: Micropaleontology, v. 5, p. 285-302.

1967. Subclass Radiolaria. In The Fossil Record, Harland, W. B. et al. (Eds.): Geol. Soc. London, p. 291-298.

1971a. Systematic classification of polycystine Radiolaria. In The Micropaleontology of Oceans, Funnell, B. M. and Riedel, W. R. (Eds.): (Cambridge Univ. Press), p. 649-661.

1971 b. Occurrence of pre-Quaternary Radiolaria in deep-sea sediments. In The Micropaleontology of Oceans, Funnell, B. M. and Riedel, W. R. (Eds.): (Cambridge Univ. Press), p. 567-594.

Riedel, W. R. and Foreman, H. P., 1961. Type specimens of North American Paleozoic Radiolaria: J. Paleontol., v. 35 , p. 628-632.

Riedel, W. R. and Funnell, B. M., 1964. Tertiary sediment cores and microfossils from the Pacific ocean floor; Geol. Soc. London Quart. J., v. 120, p. 305-368.

Riedel, W. R. and Sanfilippo, A., 1970. Radiolaria, Leg 4, Deep Sea Drilling Project. In Bader, R. G., Gerard, R. D., et al., Initial Reports of the Deep Sea Drilling Project, Volume IV: Washington (U.S. Government Printing Office), p. 503-575.

1971. Cenozoic Radiolaria from the western tropical Pacific, Leg 7. In Winterer, E. L., Riedel, W. R., et al, Initial Reports of the Deep Sea Drilling Project, Volume VII: Washington (U.S. Government Printing Office), p. 1529-1672.

, in press. Cenozoic Radiolaria. In Oceanic Micropaleont. Ramsay, A. T. S. (Ed.).

Sanfilippo, A., Burckle, L. H., Martini, E. and Riedel, W. R., in press. Radiolarians, diatoms, silicoflagellates and calcareous nannofossils in the Mediterranean Neogene: Micropaleontology.

Sanfilippo, A. and Riedel, W. R., 1970. Post-Eocene 'closed' theoperid radiolarians: Micropaleontology, v. 16 , p. $446-462$.

1973. Cenozoic Radiolaria (exclusive of theoperids, artostrobiids and amphypyndacids) from the Gulf of Mexico, Deep Sea Drilling Project Leg 10. In Worzel, J. L., Bryant, W., et al., Initial Reports of the Deep Sea Drilling Project, Volume X: Washington (U. S. Government Printing Office), p. 475-611. 
Smith, A. G., and Hallam, A., 1970. The fit of the southern continents: Nature, v. 225 , p. 139-144.

Tarling, D. H., 1971. Gondwanaland, paleomagnetism and continental drift: Nature, v. 229, p. 17-21.
Vinassa de Regny, P. E., 1900. Radiolari Miocenici Italiani: R. Accad. Sci. Bologna, ser. 5, v. 8, p. 565-595.

Wyrtki, K., 1971. Oceanographic atlas of the International Indian Ocean Expedition: Washington (U.S. Government Printing Office), 531 pp.

\section{PLATES}

On the following plates, all figures are at a magnification of $\times 250$ unless otherwise specified. The figure captions indicate the sample number, the slide number (if more than one slide was prepared), and the location of the illustrated specimen on the slide. Specimen locations are given in terms of "England Finder" coordinates (see Riedel and Foreman, 1961). The plates are arranged as follows: Plate 1, Cretaceous Radiolaria-Site 216; Plates 2 and 3, Middle Eocene Radiolaria-Site 212; Plates 4 and 5, Middle and upper Eocene Radiolaria-Sites 216 and 217; Plates 6, 7, and 8, Oligocene, Miocene, and Pliocene Radiolaria; Plates 9 and 10, Quaternary Radiolaria. 


\section{PLATE 1}

(All figures $\times 270$ )

Figure 1 Amphipyndax stocki (Campbell and Clark);216-30, CC; S1. A, F9/0.

Figure 2 Amphipyndax stocki (Campbell and Clark);216-31, CC; R35/3.

Figure 3 Dictyomitra sp. cf. D. multicostata Zittel;216-31, CC; N10/2.

Figure 4 Dictyomitra sp. cf. D. multicostata Zittel;216-30, CC; Sl. A, X5/4.

Figure 5 Dictyomitra regina (Campbell and Clark); 216-31, CC; G11/0.

Figure 6 Dictyomitra andersoni (Campbell and Clark); 216-30, CC; Sl. B, 042/2.

Figure 7 Dictyomitra andersoni (Campbell and Clark); 216-30, CC; Sl. B, S8/3.

Figure $8 \quad$ Staurodictya(?) sp. cf. S. (?) fresnoensis Foreman; 216-31, CC. F6/0.

Figure 9 Theocampe vanderhoofi Campbell and Clark; 216-30, CC; Sl. A, 07/3.

Figure 10 Diacanthocapsa sp.; 216-30, CC; S1. B, Z10/4.

Figure 11 Stichomitra(?) campi (Campbell and Clark); 216-30, CC; Sl. A, H18/4.

Figure 12 Stichomitra(?) campi (Campbell and Clark); 216-31, CC; V43/2.

Figure 13 Stichomitra sp. cf. S. cathara Foreman; 216-30, CC; S1. B, X31/2.

Figure $14 \quad$ Stichomitra sp. cf. S. cathara Foreman; 216-30, CC; Sl. B, H40/0.

Figure 15 Stichomitra compsa Foreman; 216-31, CC; M18/0.

Figure 16 Theoperid, gen. et. sp. indet.; 216-30, CC; Sl. A, W29/2.

Figure 17 Artostrobiid, gen. et. sp. indet.;216-30, CC; Sl. A, F12/0.

Figure 18 Eribotrys sp.; 216-30, CC; Sl. B, Q43/4.

Figure 19 Theoperid, gen. et. sp. indet.; 216-30, CC; Sl. A, F30/1.

Figure 20 Theoperid, gen. et. sp. indet.; 216-31, CC; V21/1. 
PLATE 1
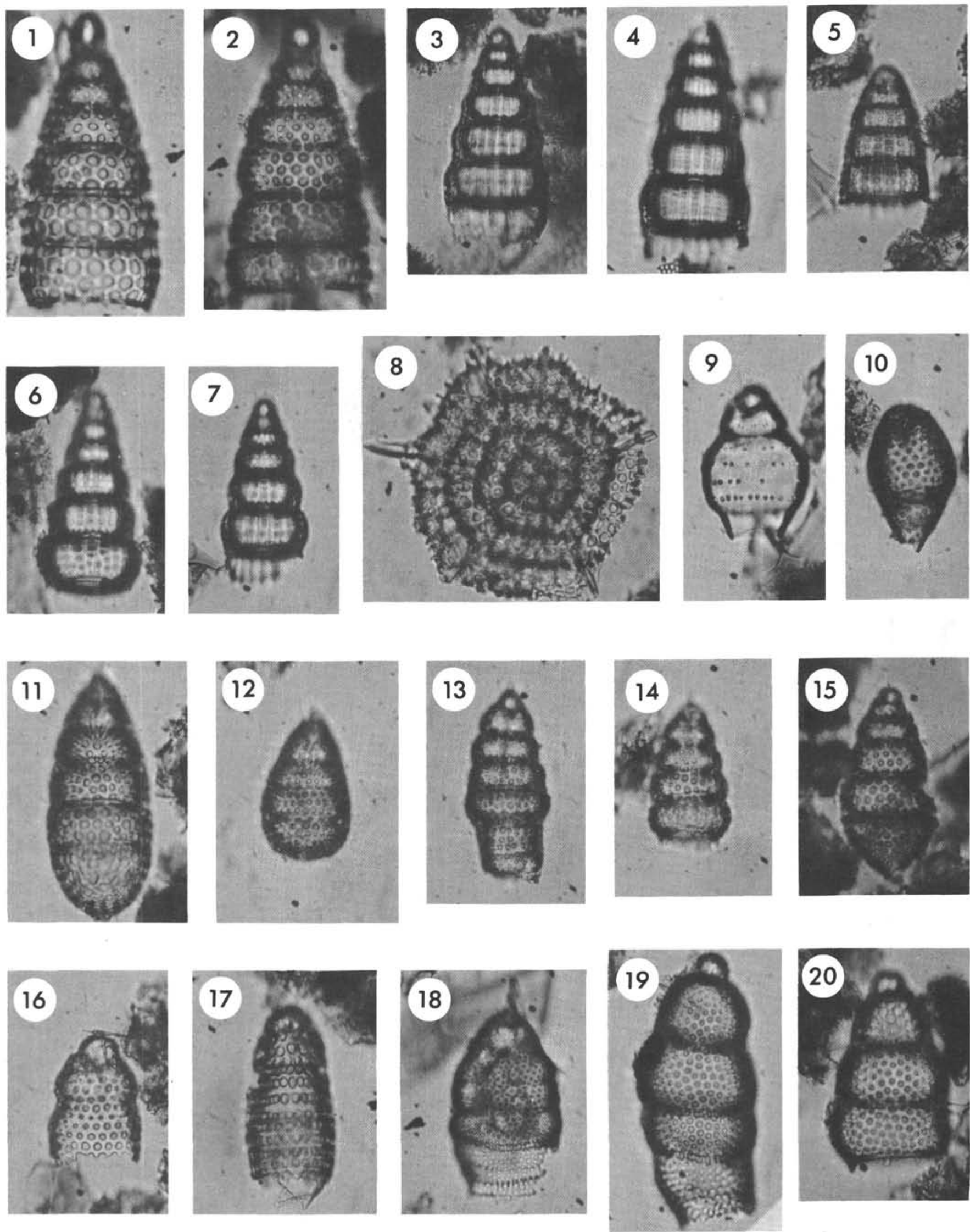


\section{PLATE 2}

(All figures $\times 270$ )

Figure 1

Lophocyrtis biaurita (Ehrenberg); 212-21-3, 71-73 cm; Sl. A, H17/0.

Figure 2 Lophocyrtis biaurita (Ehrenberg); 212-21-3, 71-73 cm; Sl. A, R36/2.

Figure 3 Theocampe mongolfieri (Ehrenberg); 212-19, CC; Sl. A, 020/0.

Figure 4

Figure 5

Figure 6

Figure 7

Figure 8

Figure 9

Figure 10

Figure 11

Figure 12

Figure 13

Figure 14

Figure 15

Figure 16

Figure 17

Figure 18

Figure 19

Figure 20

Theocampe amphora (Haeckel) group; 212-21-3, 71-73 cm; Sl. A, S46/1.

Theocampe mongolfieri (Ehrenberg); 212-23-3, 93-95 cm; Sl. A, D31/2.

Phormocyrtis striata striata Brandt; 212-23-3, 93-95 cm; Sl. A, D19/2.

Phormocyrtis striata striata Brandt; $212-21-3,71-73 \mathrm{~cm}$; Sl. A, U37/0.

Theocotyle (Theocotyle) cryptocephala cryptocephala (Ehrenberg); 212-21-3, $71-73 \mathrm{~cm}$; S1. A, N8/4.

Lamptonium fabaeforme fabaeforme (Krasheninnikov); 212-23-3, 93-95 cm; Sl. A, D23/0.

Lychnocanoma sp.; 212-20, CC; S1. A, D25/3.

Phormocyrtis embolum (EHrenberg); 212-22-3, 71-73 cm; Sl. A, J13/0.

Phormocyrtis embolum (Ehrenberg); 212-20, CC; Sl. A, W51/4.

Lychnocanoma babylonis (Clark and Campbell) group; 212-20-1, 80-82 cm; Sl. A, Q5/1.

Theoperid, gen. et. sp. indet.; 212-21-4, 76-78 cm; Sl. A, W14/3.

Theoperid, gen. et. sp. indet.; 212-21, CC; Sl. A, J/92.

Theoperid, gen. et. sp. indet.; 212-21-3, 71-73 cm; Sl. A, L13/1.

Theoperid, gen. et. sp. indet.; 212-22-4, 76-78 cm; Sl. A, F43/0.

Cryptoprora sp. cf. C. ornata Ehrenberg; 212-21-3, 71-73 cm; U7/0.

Cryptoprora sp. cf. C. ornata Ehrenberg; 212-22-3, 71-73 cm; Sl. A, W14/2.

Cryptoprora sp. cf. C. ornata Ehrenberg;212-21, CC; Sl. A, J10/0. 
PLATE 2
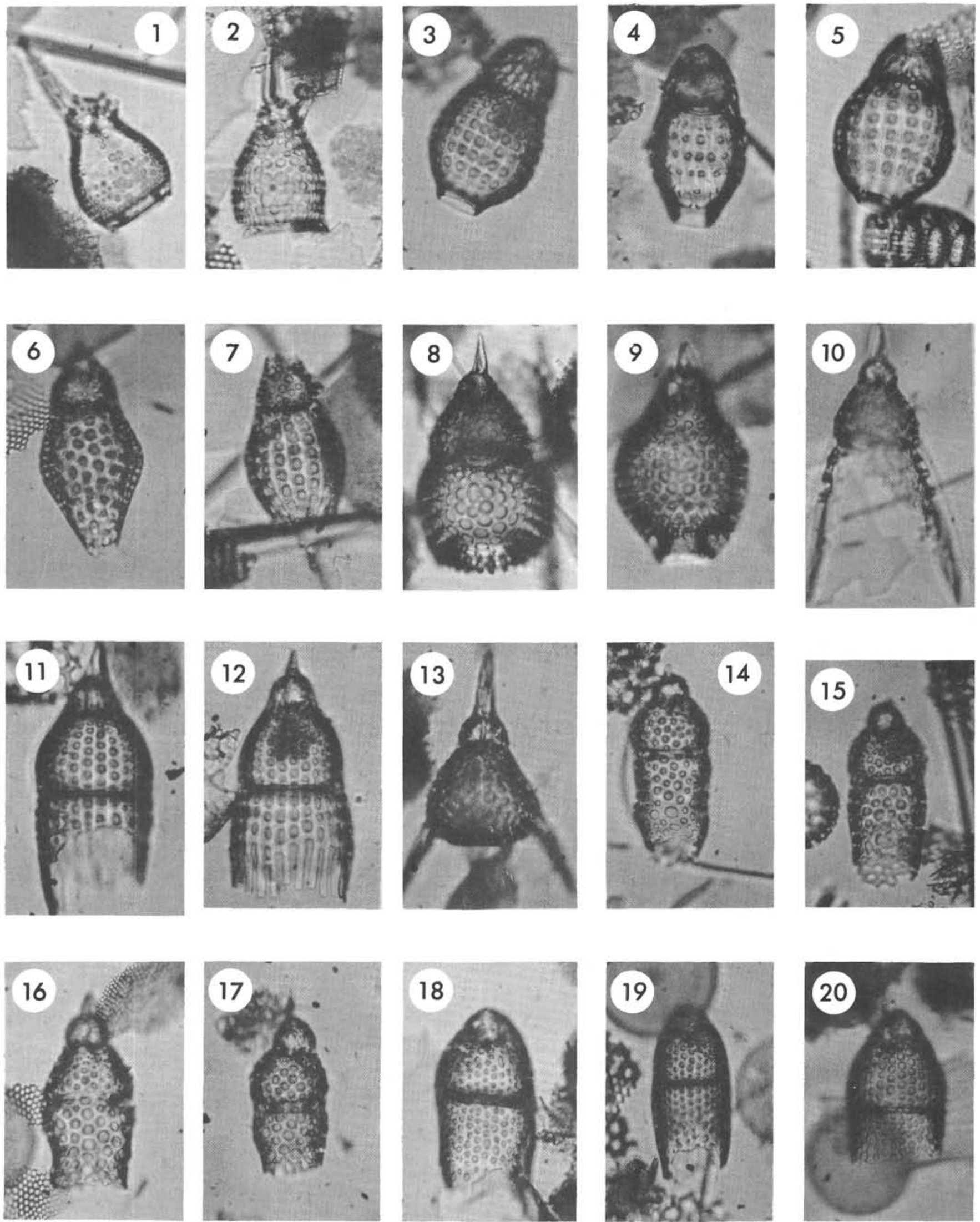
PLATE 3

(All figures $\times 270$ )

Figure 1 Giraffospyris cyrillium Sanfilippo and Riedel; 212-22-3, $71-73 \mathrm{~cm}$; Sl. A, H42/0.

Figure 2 Giraffospyris cyrillium Sanfilippo and Riedel; 212-23-3, 93-95 cm; Sl. A, Z39/3.

Figure 3 Dorcadospyris sp. cf. D. platyacantha (Ehrenberg); 212-23-1, 84-86 cm; Sl. A, M34/4.

Figure 4 Dorcadospyris sp.; 212-22-3, 71-73 cm; Sl. A, M42/3.

Figure 5 Dorcadospyris sp.; 212-22, CC; S1. A, P16/2.

Figure 6 Dorcadospyris sp.; 212-20-1, 80-82 cm; Sl. A, S39/0.

Figure 7 Giraffospyris didiceros (Ehrenberg). 212-22, CC; S1. A, W25/2.

Figure 8 Theoperid, gen. et. sp. indet.; 212-21-3, 71-73 cm, Sl. A, D18/0.

Figure 9 Theocorys sp.; 212-21-4, 76-78 cm; Sl. A, R20/4.

Figure 10 Theoperid, gen. et sp. indet.; $212-21-3,71-73 \mathrm{~cm}$; Sl. A, D16/2.

Figure 11 Theoperid, gen. et. sp. indet.; 212-22-3, 71-73 cm; Sl. A, N26/1.

Figure 12 Theoperid, gen. et. sp. indet.; 212-23-3, 93-95 cm; S1. A, M26/4.

Figure 13 Theocampe sp.; 212-21-3, $71-73 \mathrm{~cm}$; Sl. A, X12/0.

Figure $14 \quad$ Theocampe sp.; 212-21-3, 71-73 cm; Sl. A, F8/3.

Figure $15 \quad$ Theocampe sp.; 212-21-4, 76-78 cm; Sl. A, G16\&3.

Figure $16 \quad$ Lithomitra docilis Foreman; 212-21-3, $71-73 \mathrm{~cm}$; Sl. A, L10/1.

Figure 17 Theoperid, gen. et. sp. indet.; 212-20, CC; Sl.A, S10/3.

Figure 18 Theoperid, gen. et. sp. indet.; 212-23-2, 79-81 cm; Sl.A, E20/1.

Figure 19 Theoperid, gen. et. sp. indet.; 212-21-4, 76-78 cm; Sl.A, V31/3. 
PLATE 3
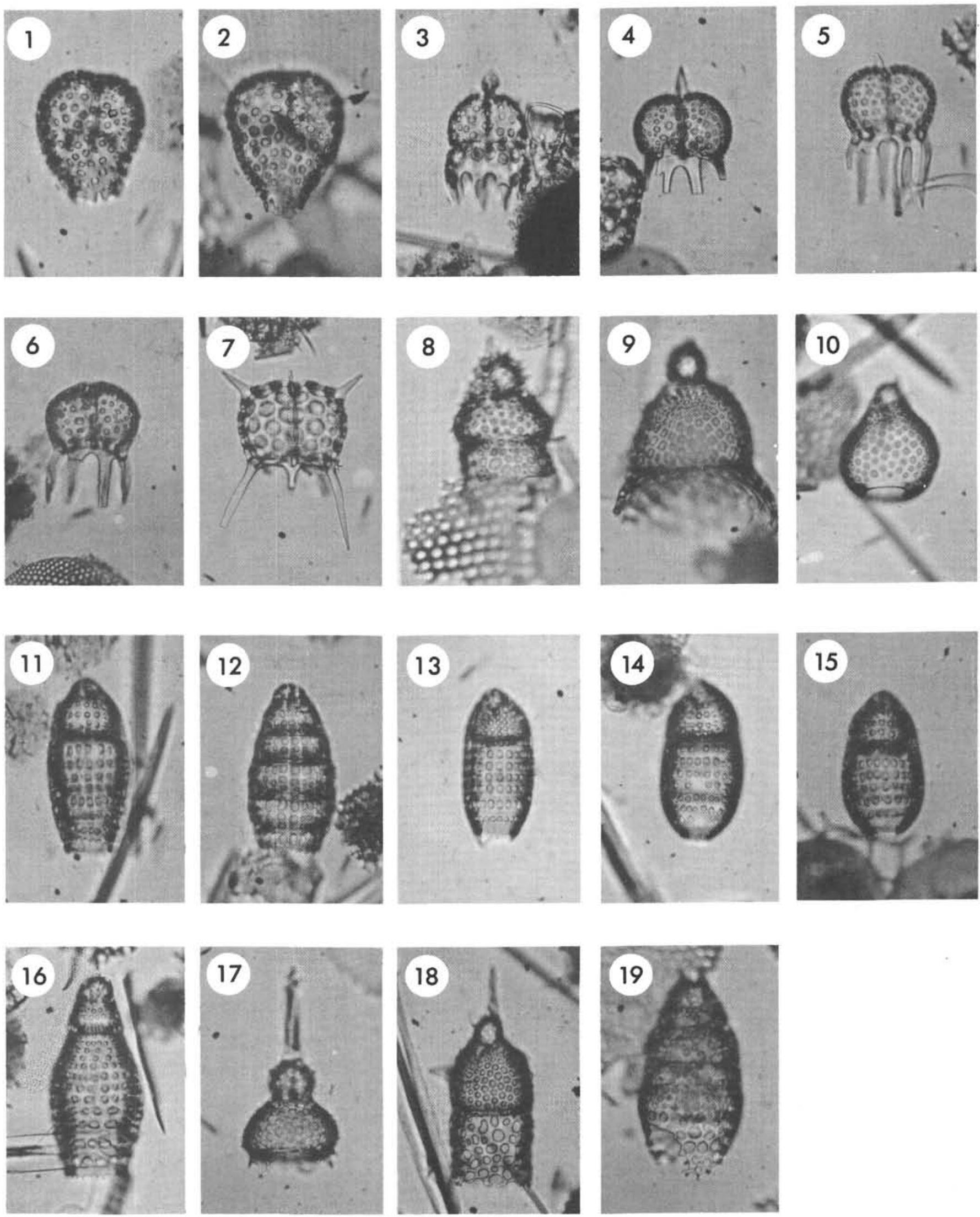
PLATE 4

(All figures $\times 270$ )

Figure 1 Calocyclas hispida (Ehrenberg); 217-10, CC; S1.B, Y $9 / 2$.

Figure 2 Theocampe amphora (Haeckel) group; 217-10, CC; SI.A, U36/4.

Figure 3

Dendrospyris sp.; 216-15, CC; Sl.A, R24/0.

Figure 4

Dorcadospyris confluens (Ehrenberg); 217-10, CC, Sl.A, L35/3.

Figure $5 \quad$ Phormocyrtis embolum (Ehrenberg); 217-10, CC; Sl.B, L11/2.

Figure 6 Thyrsocyrtis rhizodon Ehrenberg; 216-17, CC; Sl.A, Q47/2.

Figure 7 Thyrsocyrtis rhizodon Ehrenberg; 216-16, CC; Sl.A, $024 / 3$.

Figure 8 Thyrsocyrtis rhizodon Ehrenberg; 217-10, CC; S1.B, $\mathrm{G} 12 / 0$.

Figure 9 Thyrsocyrtis rhizodon Ehrenberg; 217-10, CC; S1.B, N8/4.

Figure 10 Theocotyle (Theococotylissa) ficus (Ehrenberg); 217-10, CC; S1.B, N25/3.

Figure 11 Theocotyle (Theocotylissa) ficus (Ehrenberg); 217-10, CC; Sl.B, W30/0.

Figure 12 Podocyrtis papalis Ehrenberg; 217-10, CC; Sl.B, F28/4.

Figure 13 Theoperid, gen. et. sp. indet.; 216-15, CC; Sl.A, W36/0.

Figure 14 Theoperid, gen. et. sp. indet.; 217-9, CC; Sl.A, 039/4.

Figure $15 \quad$ Podocyrtis (Lampterium) mitra Ehrenberg; 216-17, CC; Sl.A, X10/4.

Figure $16 \quad$ Podocyrtis sp.; 216-17, CC; Sl.A, K16/1.

Figure 17 Podocyrtis sp.; 217-10, CC; S1.B, N32/4.

Figure $18 \quad$ Podocyrtis (Lampterium) sinuosa Ehrenberg(?); 217-10, CC; Sl.A, T11/0. 
PLATE 4
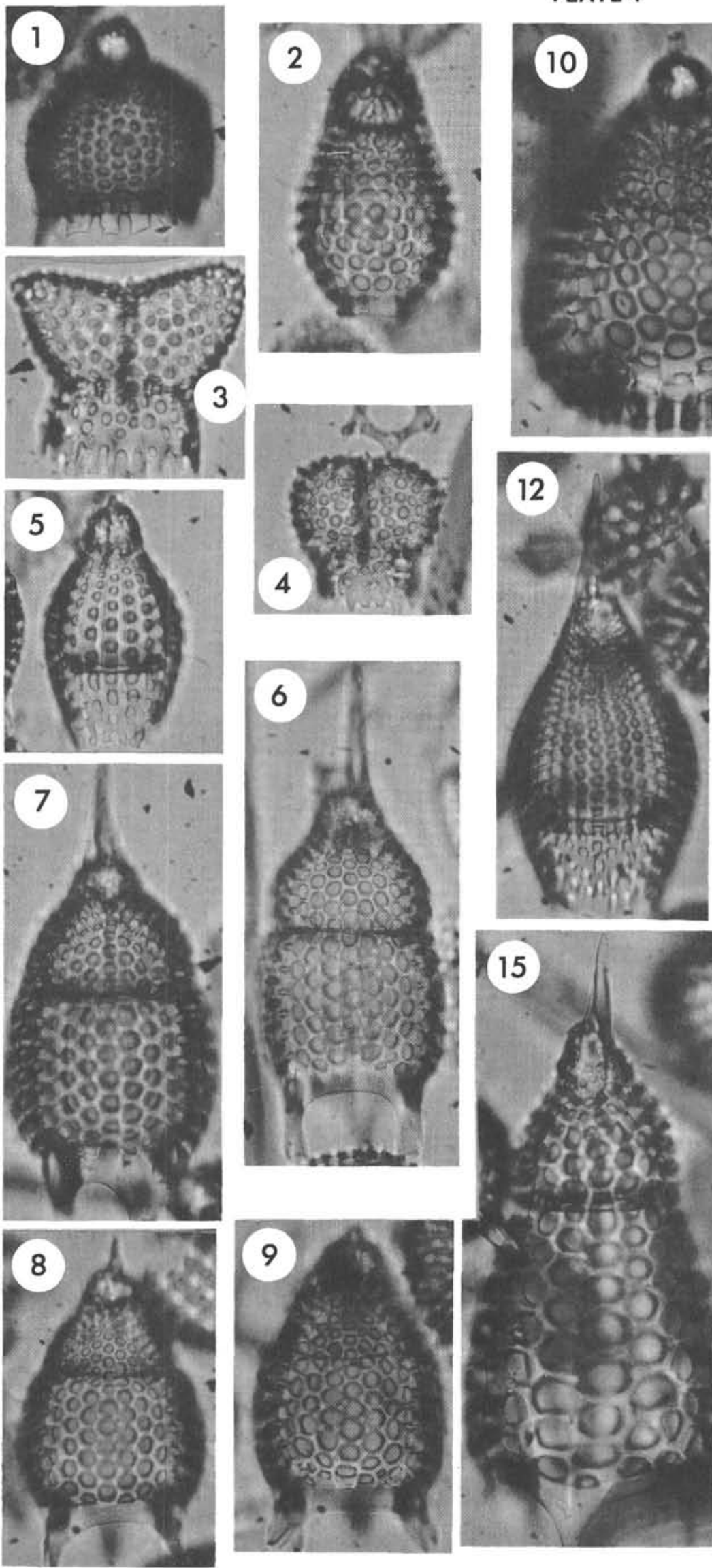
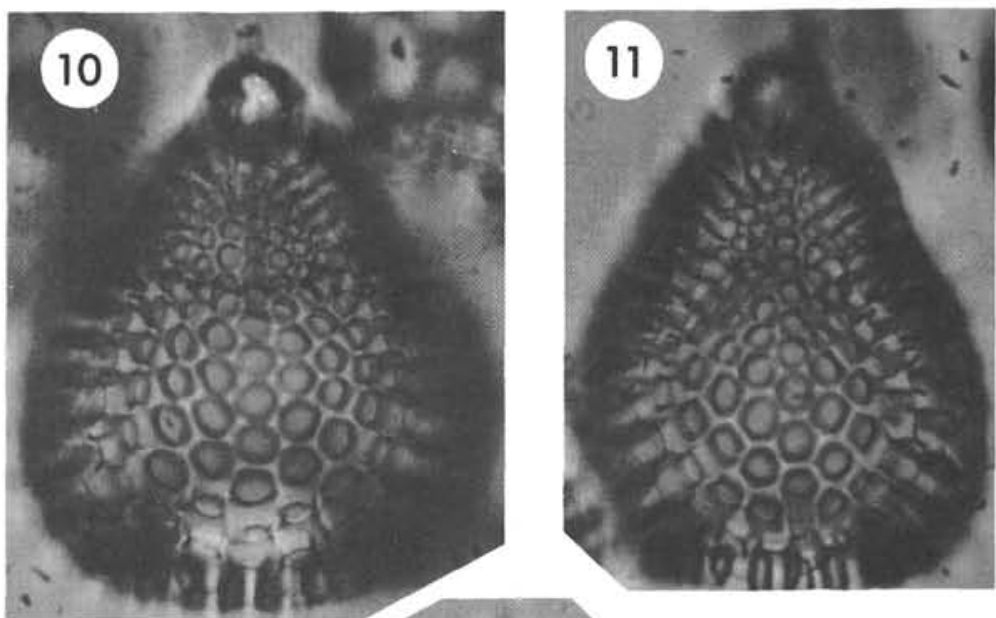

\section{2}
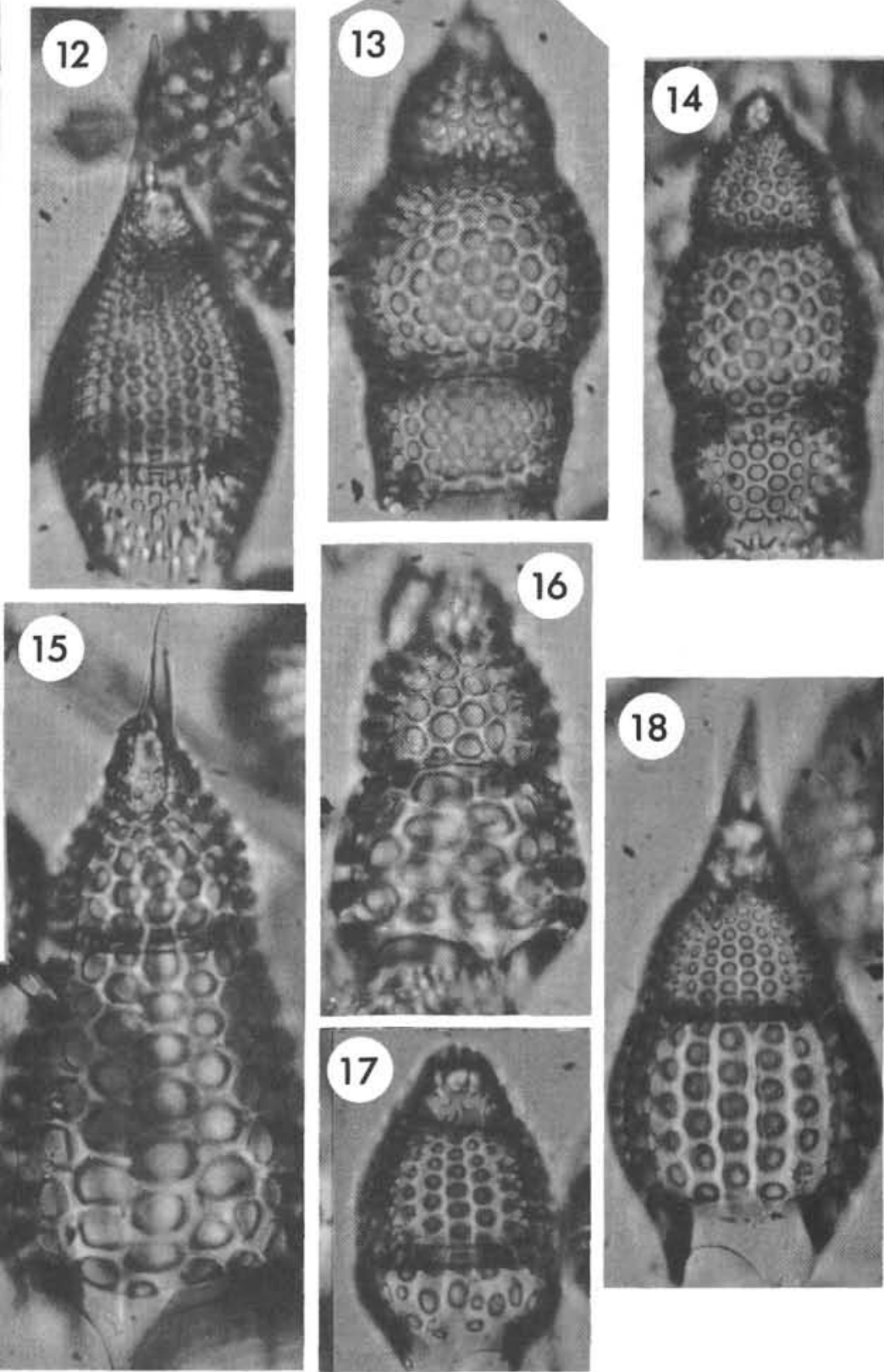


\section{PLATE 5}

(All figures $\times 270$ )

Figure 1

Figure 2

Figure 3

Figure 4

Figure 5

Figure 6

Figure 7

Figure 8

Figure 9

Figure 10

Figure 11

Figure 12

Figure 13

Figure 14

Figure 15

Figure 16

Figure 17

Figure 18
Theocampe mongolfieri (Ehrenberg); 216-17, CC; Sl.A, N28/2.

Calocyclas turris Ehrenberg;216-16, CC; Sl.A, Q31/1.

Eusyringium lagena (Ehrenberg); 217-10-4, 70-72 cm; Sl.A, X6/2.

Eusyringium fistuligerum (Ehrenberg); 217-10-1, $108-110 \mathrm{~cm}$; S1.A, V14/3.

Lophocyrtis (?) jacchia (Ehrenberg); 217-9, CC; Sl.A, $\mathrm{H} 22 / 1$.

Artophormis barbadensis (Ehrenberg); 217-9, CC; S1.A, P22/0.

Thyrsocyrtis bromia Ehrenberg; 216-16, CC; Sl.A, $\mathrm{T} 45 / 2$.

Calocycloma ampulla (Ehrenberg); 217-10-1, 108-110 $\mathrm{cm}, \mathrm{Sl} . \mathrm{A}, \mathrm{H} 23 / 3$.

Cryptoprora ornata Ehrenberg; 217-9, CC; Sl.A, P8/0.

Lychnocanoma sp.; 216-17-1, 110-112 cm; Sl.A, Q13/0.

Podocyrtis (Lampterium) trachodes Riedel and Sanfilippo;217-10-1, 108-110 cm; S1.A, P13/1.

Podocyrtis (Lampterium) trachodes Riedel and Sanfilippo;217-10-1, 108-110 cm; Sl.A, S23/3.

Lithocyclia aristotelis (Ehrenberg) group; 216-15, CC; S1.A, E28/4.

Lithocyclia aristotelis (Ehrenberg) group; 217-9, CC; S1.A, F32/4.

Thyrsocyrtis tetracantha (Ehrenberg); 216-16, CC; Sl.A, 046/1.

Thyrsocyrtis triacantha (Ehrenberg); 216-17-1, $110-112 \mathrm{~cm}$; Sl.B, M25/2.

Theoperid, gen. et. sp. indet.; 217-9, CC; Sl.A, T9/0.

Rhopalocanium ornatum Ehrenberg; 216-18, CC; Sl.A, N31/0. 


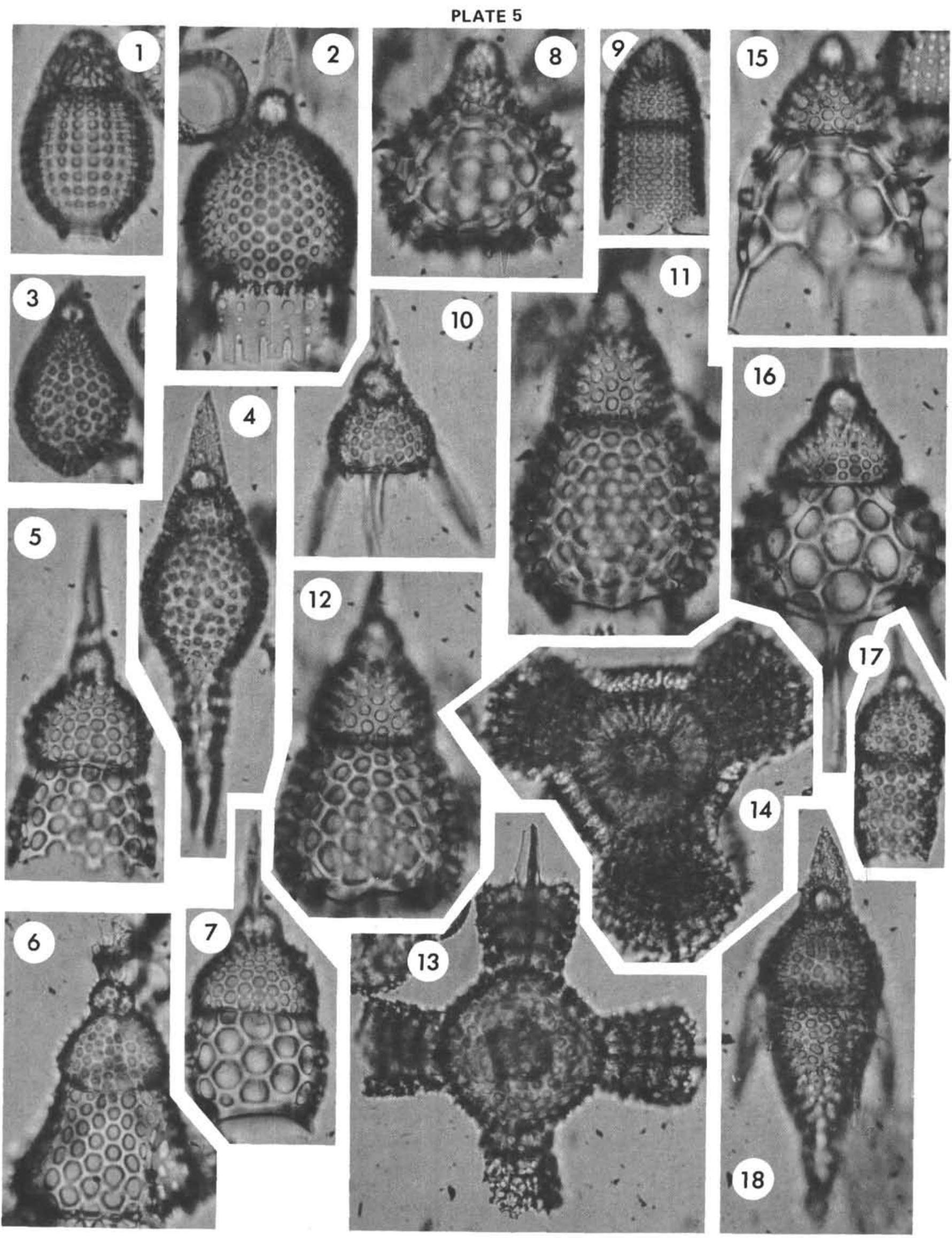




\section{PLATE 6}

(Figures 1 through 15 are $\times 270$; figures 16 through 19 are $\times 175$ )

Figure 1

Figure 2

Figure 3

Figure 4

Figure 5

Figure 6

Figure 7

Figure 8

Figure 9

Figure 10

Figure 11

Figure 12

Figure 13

Figure 14

Figure 15

Figure 16

Figure 17

Figure 18

Figure 19
Artophormis gracilis Riedel;216-13, CC; Sl.B, M42/3.

Theocorys spongoconum Kling; 217-6, CC; Sl.A, $\mathrm{X} 36 / 4$.

Calocycletta acanthocephala (Ehrenberg); 216-12, CC; Sl.A, Z42/0.

Lithocyclia angustum (Riedel); 216-12, CC; Sl.A, F27/0.

Lithocyclia crux Moore; 216-14, CC; S1.A, S38/4.

Botryopyle dictyocephalus Haeckel group; 217-8-6, $148-150 \mathrm{~cm}$; Sl.A, D5/1.

Eucyrtidium cienkowskii Haeckel group; 217-7-5, 68-70 cm; Sl.A, G29/3.

Dendrospyris sp.; 217-8-6, 148-150 cm; Sl.A, S33/4.

Dorcadospyris sp.; 216-13, CC; S1.B, D34/0.

Theoperid, gen. et. sp. indet.; 216-13, CC; Sl.B, Z38/4.

Theoperid, gen. et. sp. indet.; 216-13, CC; Sl.B, G41/0.

Theoperid, gen. et. sp. indet.; 216-13, CC; Sl.A, $\mathrm{E} 41 / 0$.

Theoperid, gen. et. sp. indet.; 216-14, CC; Sl.A, K19/0.

Theocampe pirum (Ehrenberg); 216-14, CC; Sl.A, L29/4.

Dicolocapsa microcephala; 216-13, CC; Sl.A, Q40/3.

Dorcadospyris circulus (Haeckel); 216-12-1, 110-115 cm; S1.A, P20/0.

Dorcadospyris ateuchus (Ehrenberg); 216-9-3, top; Sl.A, F16/0.

Dorcadospyris spinosa Moore; 216-8, CC; Sl.A, J8/2.

Dorcadospyris sp.; 216-12-1, 110-115 cm; Sl.A, 022/3. 
PLATE 6
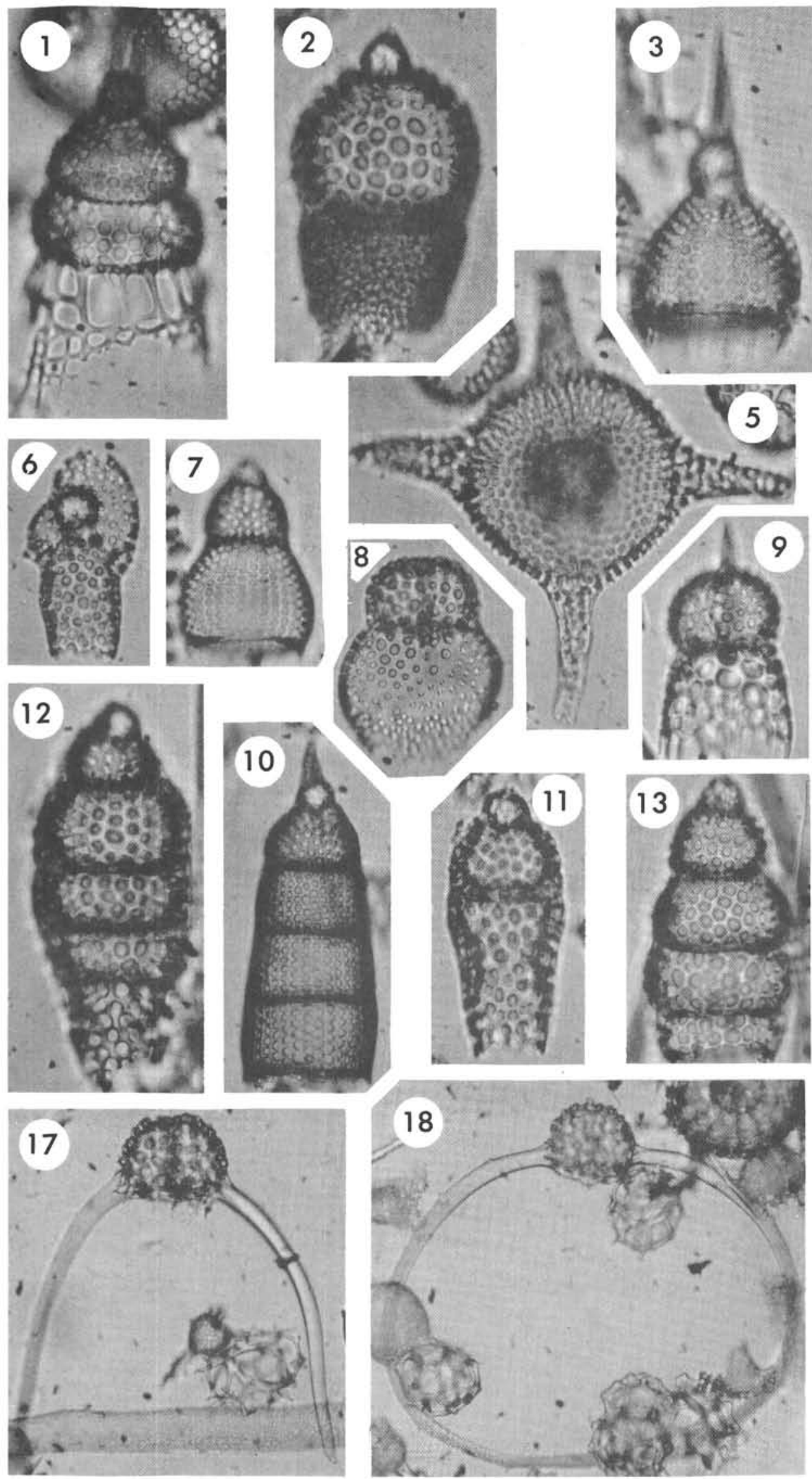
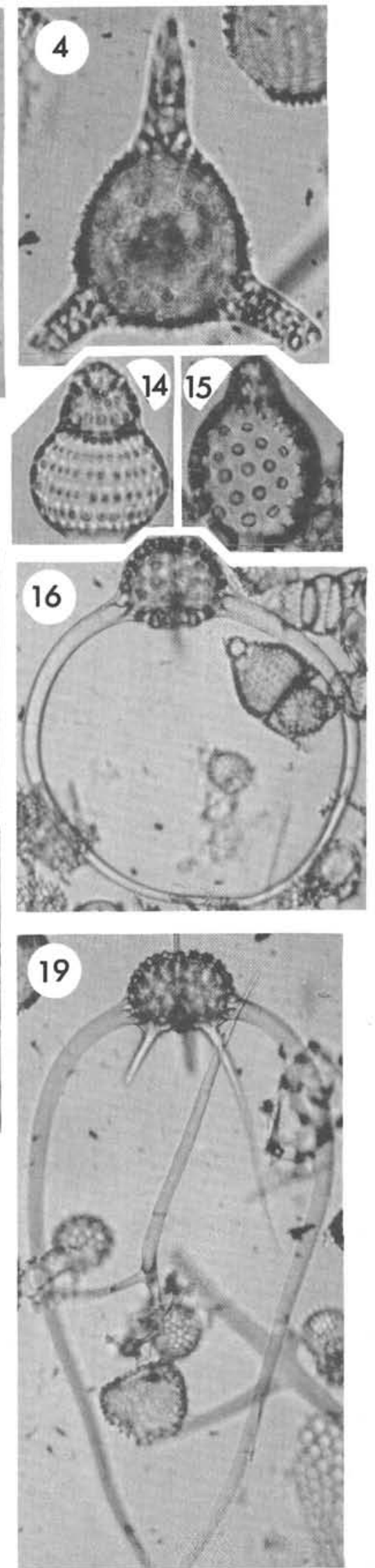


\section{PLATE 7}

(All figures $\times 270$ )

Figure 1

Figure 2

Figure 3

Figure 4

Figure 5

Figure 6

Figure 7

Figure 8

Figure 9

Figure 10

Figure 11

Figure 12

Figure 13

Figure 14

Figure 15

Figure 16

Figure 17

Figure 18

Figure 19

Figure 20
Cannartus tubarius (Haeckel); 216, CC; S1.A, V30/1.

Cannartus laticonus Riedel;216A-3, CC; SI.B. X19/0.

Ommatartus antepenultimus Riedel and Sanfilippo; 214-16, CC; Sl.A, X19/2.

Ommatartus antepenultimus Riedel and Sanfilippo; 217-4, CC; Sl.A, 016/4.

Ommatartus penultimus (Riedel); 213-8-3, $58-60 \mathrm{~cm}$; Sl.A, P12/0.

Cannartus (?) petterssoni Riedel and Sanfilippo; 214-17, CC; Sl.A, D16/2.

Cannartus (?) petterssoni Riedel and Sanfilippo; 214-16, CC; Sl.A, S36/0.

Cannartus (?) sp. cf. C. (?) petterssoni Riedel and Sanfilippo; 214-16, CC; Sl.A, G27/0.

Ommatartus highesi (Campbell and Clark); 214-14, CC; Sl.A, G12/2.

Ommatartus hughesi (Campbell and Clark); 217-4, CC; Sl.A, M44/0.

Crytocapsella tetrapera (Haeckel); 216-6, CC; Sl.B, $\mathrm{T} 40 / 0$.

Crytocapsella japonica (Nakaseko); 216-6, CC; Sl.A, Y29/0.

Crytocapsella japonica (Nakaseko); 216-5, CC; Sl.A, F $36 / 3$.

Artostrobium doliolum Riedel and Sanfilippo; 213-8-2, 10-12 cm; Sl.A, S10/1.

Artostrobium doliolum Riedel and Sanfilippo; 214-10, CC; Sl.A, G40/0.

Acrobotrys tritubus Riedel; 213-8-2, 10-12 cm; Sl.A, $\mathrm{X} 20 / 4$.

Solenosphaera sp. cf. $S$. omnitubus Riedel and Sanfilippo; 213-8-2, 10-12 cm; Sl.A, K9/0.

Phormostichoartus corona Haeckel; 213-8-3, 58-60 cm; Sl.A, G26/0.

Spongaster klingi Riedel and Sanfilippo; 213-8-2, 10-12 cm; Sl.A, Q45/0.

Spongaster klingi Riedel and Sanfilippo; 214-11, CC; Sl.A, Q40/1. 
PLATE 7
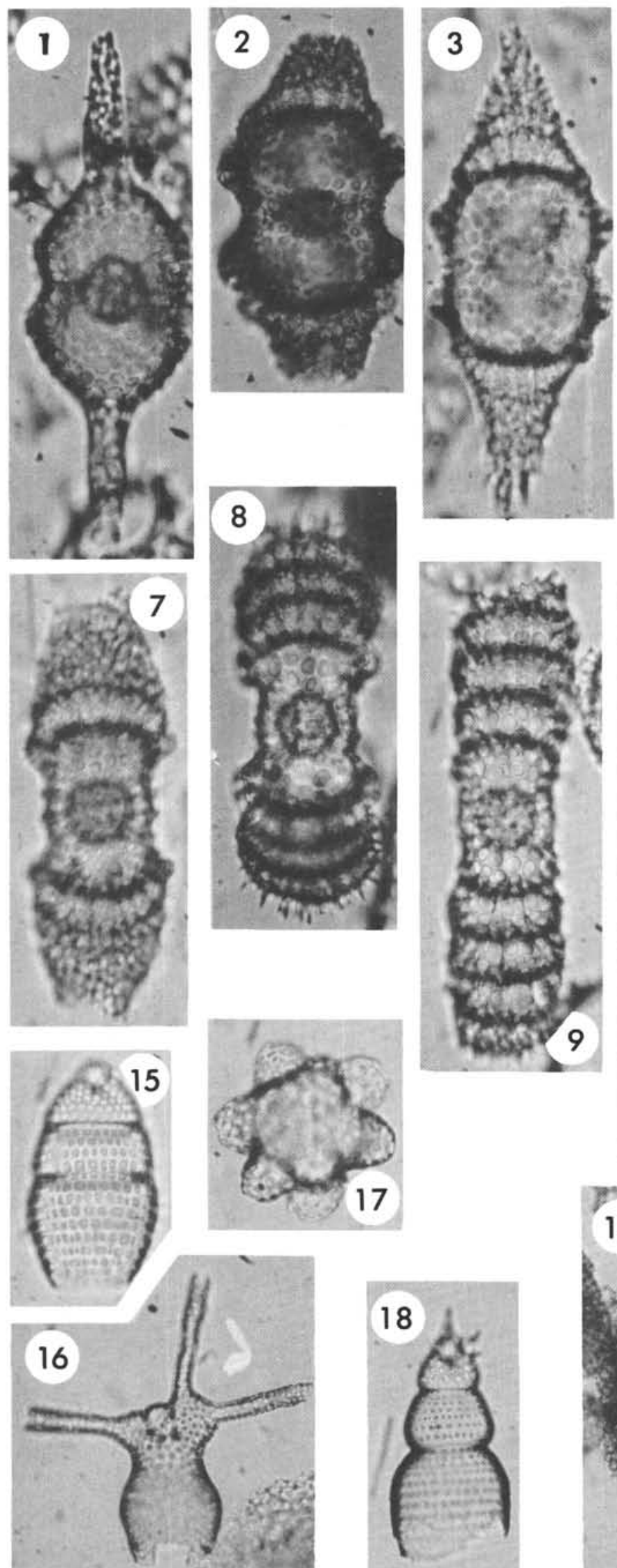

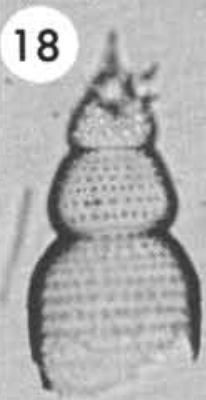

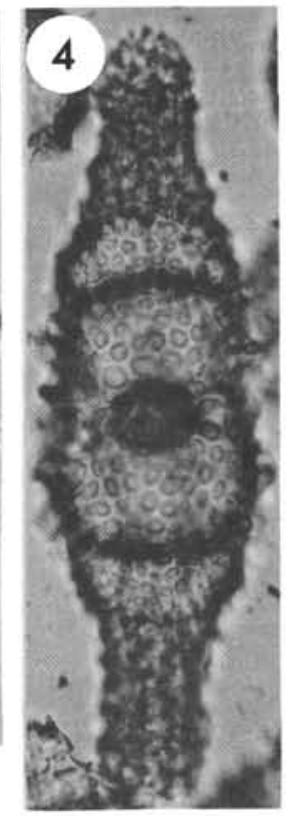
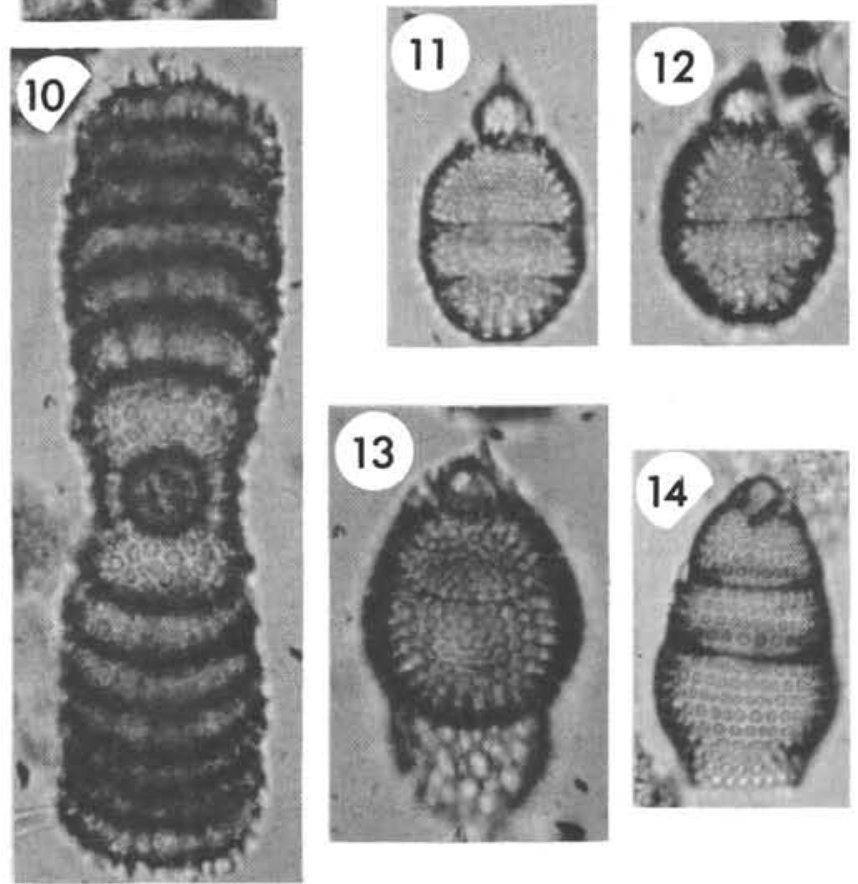
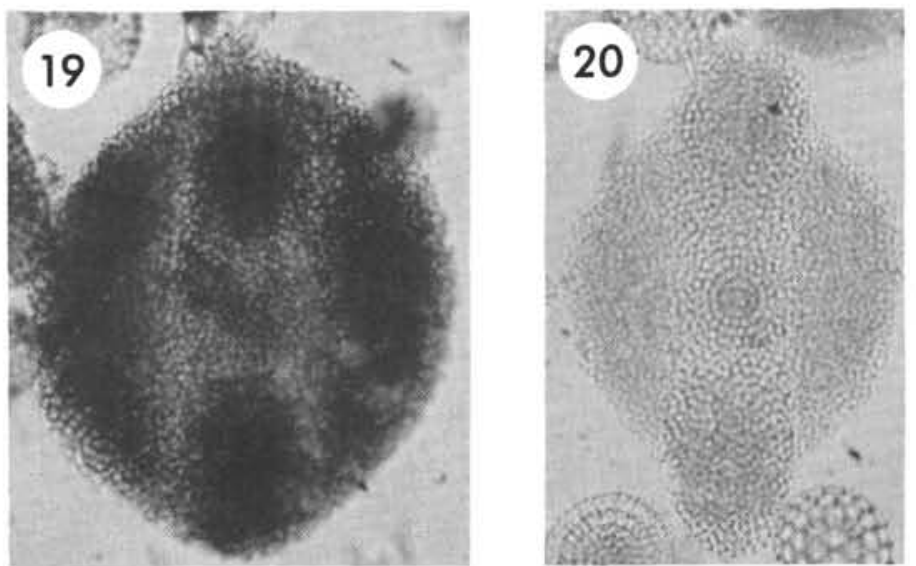


\section{PLATE 8}

(All figures $\times 270$ except 9 and 10, which are $\times 175$ )

Figure $1 \quad$ Carpocanopsis cristatum (Carnevale) (?);216A-5, CC; Sl.A, M36/2.

Figure 2 Carpocanistrum sp.; 216A-5, CC; Sl.A, Z40/2.

Figure 3 Carpocanopsis favosum (Haeckel); 216-5, CC; Sl.A, $\mathrm{U} 34 / 4$.

Figure 4 Carpocanopsis bramlettei Riedel and Sanfilippo; 216-5, CC; S1.B, K39/3.

Figure 5 Carpocanepsis bramlettei Riedel and Sanfilippo; 216A-5, CC; Sl.A, F20/4.

Figure 6

Carpocanopsis sp.; 216A-3, CC; S1.A, T22/1.

Figure 7 Carpocanopsis cingulatum Riedel and Sanfilippo; 216-5, CC; Sl.A, T39/2.

Figure 8 Carpocanopsis sp. cf. C. cingulatum Riedel and Sanfilippo; 213-8-3, 58-60 cm; Sl.A, J10/3.

Figure 9

Calocycletta costata (Riedel); 216A-5, CC; Sl.A, Q17/3.

Figure 10 Dorcadospyris dentata Haeckel; 216A-5, CC; Sl.A, $\mathrm{M} 18 / 2$.

Figure $11 \quad$ Pterocanium prismatium Riedel; 215-4, CC; Sl.A, F $35 / 0$.

Figure 12 Stichocorys peregrina (Riedel); 215-4, CC; Sl.A, $\mathrm{X} 10 / 0$.

Figure 13 Stichocorys delmontensis (Campbell and Clark); 217-4, CC; Sl.A, W11/0.

Figure $14 \quad$ Lithopera sp. cf. L. neotera Sanfilippo and Riedel; 217-5, CC; S1.A, F20/4.

Figure $15 \quad$ Spongaster pentas Riedel and Sanfilippo; 214-7, CC; Sl.A, K20/1.

Figure 16 Theoperid, gen. et. sp. indet.; 215-8-5, 78-80 cm; $\mathrm{H} 27 / 2$.

Figure 17 Theoperid, gen. et. sp. indet.; 215-4, CC; S1.A, S22/3.

Figure 18 Theoperid, gen. et. sp. indet.; 215-6, CC; S1.A, V15/4.

Figure 19 Theoperid, gen. et. sp. indet.; 215-4, CC; S1.A, X25/2.

Figure 20 Theoperid, gen. et. sp. indet.; 215-6, CC; S1.A, Y21/0. 
PLATE 8
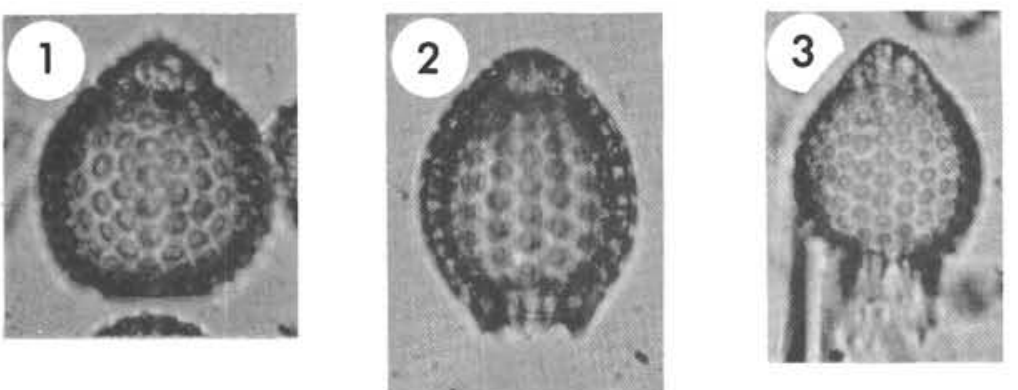
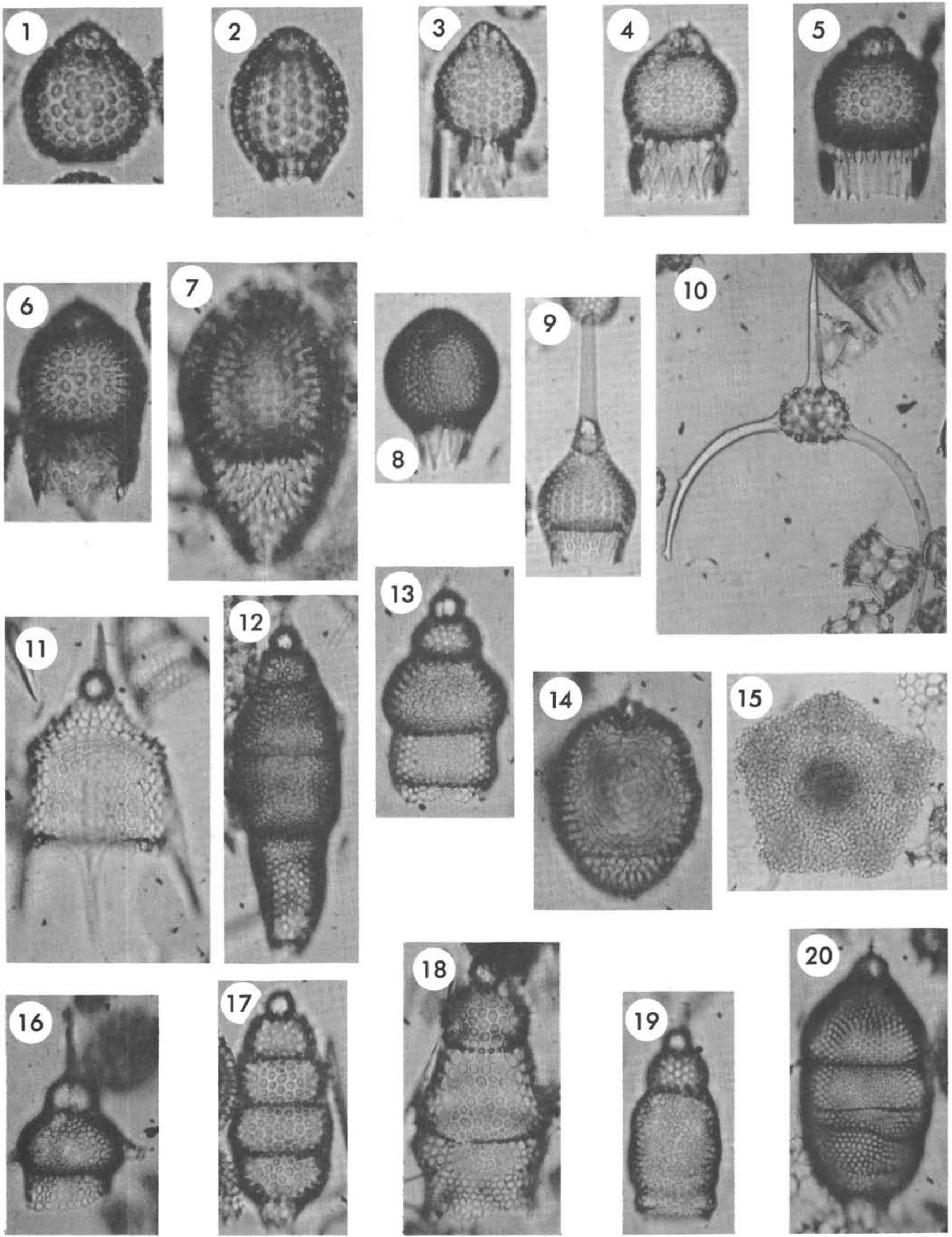


\section{PLATE 9}

(All figures $\times 270$ except 7 , which is $\times 175$ )

Figure 1

Figure 2

Figure 3

Figure 4

Figure 5

Figure 6

Figure 7

Figure 8

Figure 9

Figure 10

Figure 11

Figure 12

Figure 13

Figure 14

Figure 15

Figure 16

Figure 17

Figure 18

Figure 19

Figure 20
Collosphaera tuberosa Haeckel; 214-1-5, top; Sl.A, M25/2.

Anthocyrtidium angulare Nigrini; 215-1-1, 1-3 cm; Sl.A, Q8/2.

Amphirhopalum ypsilon Haeckel; 214-1, CC; Sl.A, $\mathrm{S} 25 / 2$.

Amphirhopalum ypsilon Haeckel; 214-4, CC; Sl.A, D24/3.

Ommatartus tetrathalamus (Haeckel); 214-1, CC; Sl.A, R43/4.

Spongaster tetras tetras Ehrenberg; 213-1-6, 148-150 cm; S1.A, Z20/2.

Hymeniastrum euclidis Haeckel; 213-8-3, 58-60 cm; S1.A, E20/0.

Pterocanium praetexum (Ehrenberg); 214-6, CC; Sl.A, X30/2.

Pterocanium praetexum (Ehrenberg); 215-1-1, 1-3 cm; Sl.A, U20/3.

Ommatartus tetrathalamus (Haeckel); 213-1-6, 148-150 cm; Sl.A, W22/2.

Euchitonia elegans (Ehrenberg); 213-1-6, 148-150 cm; Sl.A, J24/1.

Euchitonia sp. cf. E. furcata (Ehrenberg); 213-1-6, 148-150 cm; Sl.A, T21/0.

Euchitonia sp.; 213-8-3, 58-60 cm; S1.A, E16/0.

Euchitonia sp.; 213-1-6, 148-150 cm; Sl.A, Y47/2.

Hymeniastrum euclidis Haeckel; 213-8-3, 58-60 cm; S1.A, E20/0.

Dictyocoryne sp.; 214-1, CC; Sl.A, Q18/0.

Dictyocoryne sp.; 214-1, CC; S1.A, F26/1.

Spongodiscid;214-11, CC; S1.A, 09/0.

Botryocyrtis sp. cf. B. scutum (Harting); 214-3, CC; S1.A, M19/0.

Botryocyrtis scutum (Harting); 213-1-6, 148-150 cm; S1.A, K25/0. 
PLATE 9

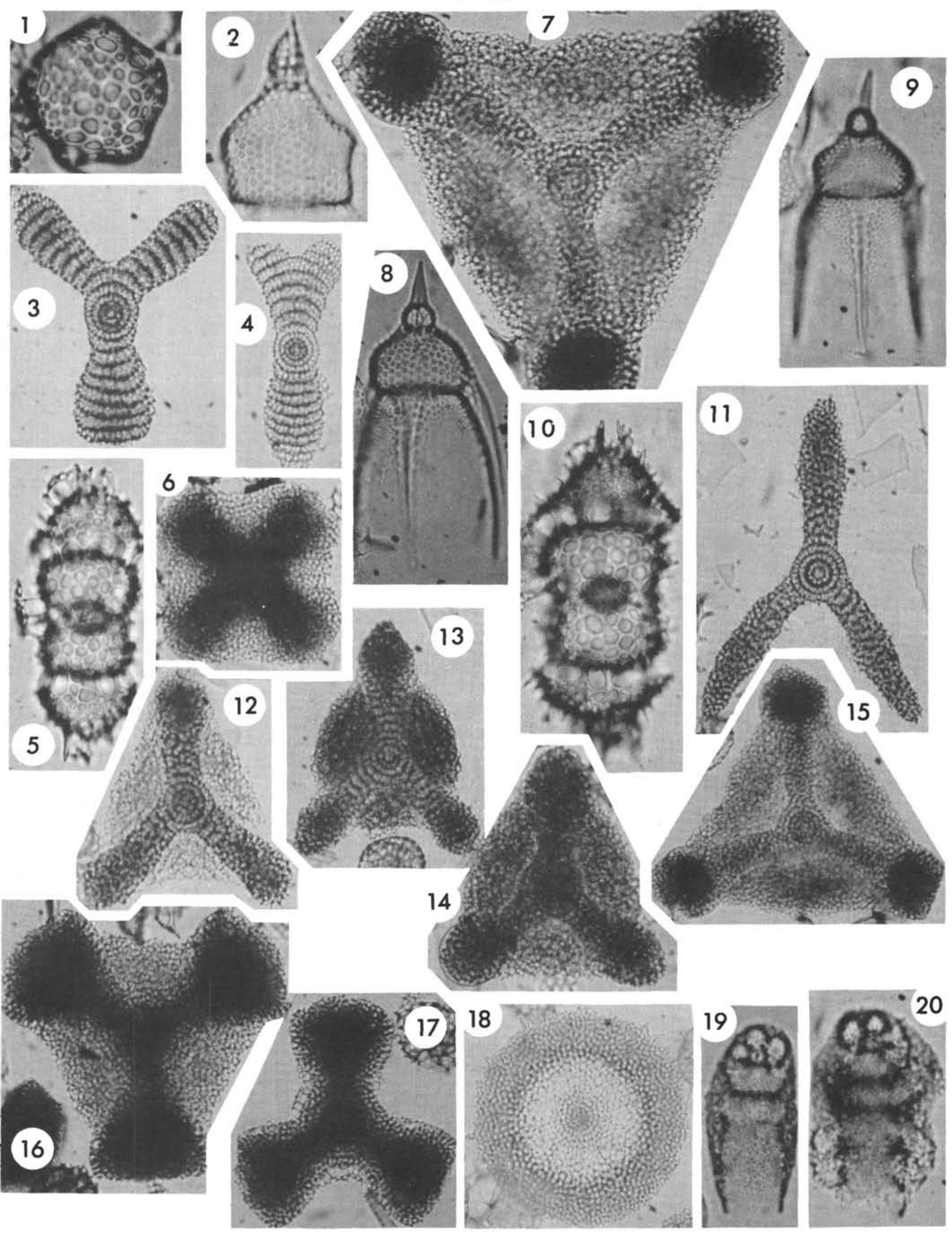


PLATE 10

(All figures $\times 270$ )

Figure 1

Figure 2

Figure 3

Figure 4

Figure 5

Figure 6

Figure 7

Figure 8

Figure 9

Figure 10

Figure 11

Figure 12

Figure 13

Figure 14

Figure 15

Figure 16

Figure 17

Figure 18

Figure 19
Polysolenia spinosa (Haeckel); 214-2-5, top; Sl.A, M34/4.

Lamprocyclas heteroporos Hays; 214-6, CC; Sl.A, S18/4.

Lamprocyclas heteroporos Hays; 214-2, CC; Sl.A, M6/4.

Lamprocyclas sp. cf. L. heteroporos Hays; 214-3, CC; S1.A, Y26/1.

Lamprocyclas heteroporos Hays; 214-3-2, 70-72 cm; S1.A, 032/2.

Theocorythium trachelium (Ehrenberg); 214-3-4, $70-72 \mathrm{~cm} ; \mathrm{H} 11 / 1$.

Theocorythium trachelium (Ehrenberg); 215-1-1, 1-3 cm; Sl.A, Y8/4.

Theocorythium trachelium (Ehrenberg); 215-1-1, 1-3 cm; Sl.A, D41/1.

Eucyrtidium calvertense Martin; 213-1-6, 148-150 cm; Sl.A, T21/4.

Artostrobium miralestense (Campbell and Clark); 215-1-1, 46-48 cm; Sl.A, V35/0.

Lamprocyclas maritalis maritalis Haeckel; 214-2-5, top; Sl.A, S43/0.

Lamprocyclas maritalis (Haeckel) polypora Nigrini; 214-2-5, top; S1.A, X16/0.

Lamprocyclas sp.; 214-3-2, 70-72 cm; Sl.A, D42/1.

Eucyrtidium hexagonatum Haeckel; 213-1-6, 148-150 cm; Sl.A, Q9/0.

Eucyrtidium acuminatum (Ehrenberg); 214-4, CC; Sl.A, K31/0.

Lithocampe sp.; 214-3-2, 70-72 cm; Sl.A, T33/4.

Eucyrtidium sp.; 214-6, CC; S1.A, M46/4.

Eucyrtidium sp.; 214-6, CC; Sl.A, Y25/0.

Lophophaena sp.; 214-1, CC; Sl.A, S14/4. 
PLATE 10
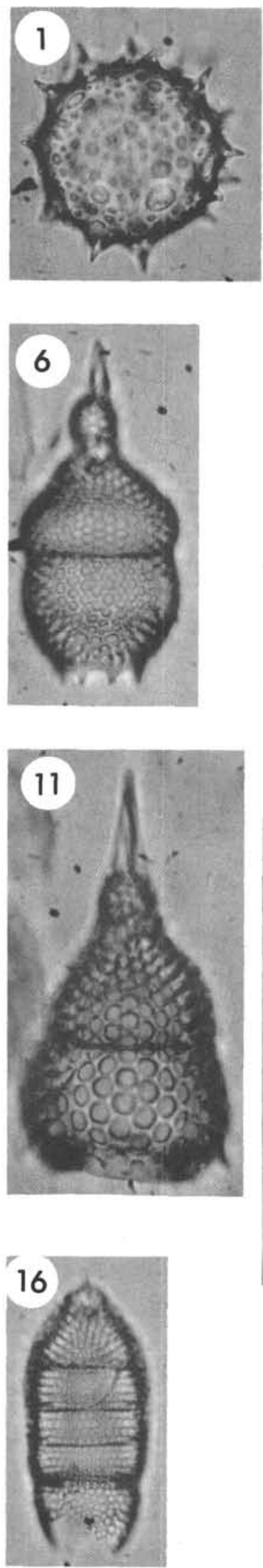
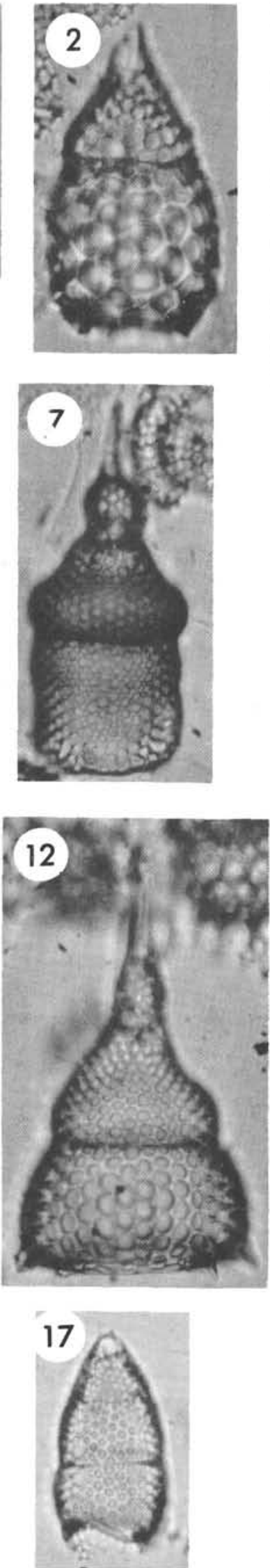
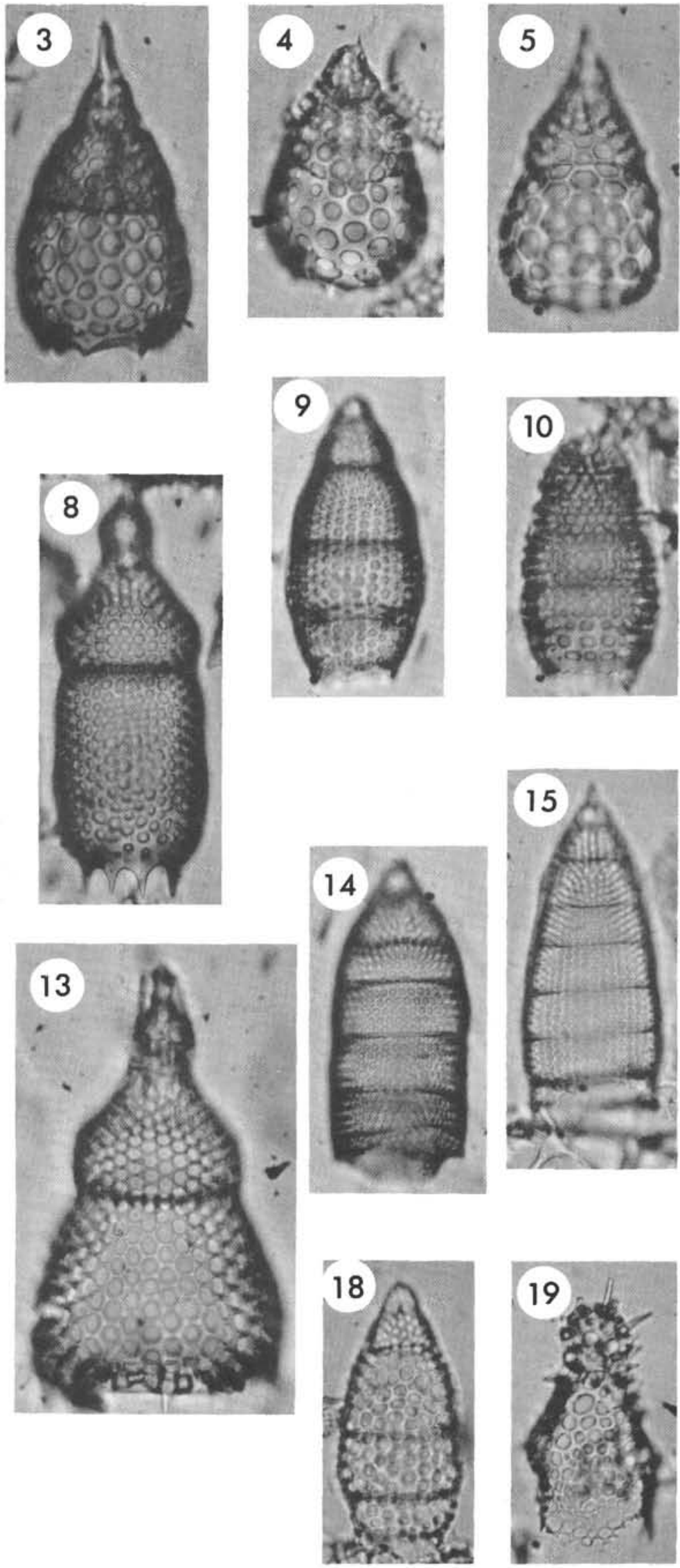